\title{
A revision of Ziziphus (Rhamnaceae) in Borneo
}

\author{
Daniel Cahen $^{1} \mathbb{D}$, Jessica Rickenback ${ }^{2,3}$ \& Timothy M. A. Utteridge ${ }^{1}$
}

Summary. The genus Ziziphus (Rhamnaceae) is revised for Borneo. 13 species are recognised using morphological evidence, including three new endemic species: Ziziphus cuspidata, Z. domatiata and Z. puberula. Borneo is therefore the island with the greatest known diversity of Ziziphus species. The area surrounding Mount Kinabalu is particularly diverse, with nine species occurring in Ranau. Two new varieties of Z. borneensis are also described here, Z. borneensis var. ranggam and Z. borneensis var. velutina, five new synonyms are established, including the placement of Z. elmeri as a synonym of Colubrina beccariana. A taxonomic treatment, including a preliminary IUCN conservation status assessment, is presented for each species and variety.

Key Words. conservation, IUCN, Malesia, South-East Asia, systematics, taxonomy, tropical climbers.

\section{Introduction}

Ziziphus Mill. is a genus in the Rhamnaceae of about 80 species of deciduous and evergreen shrubs, climbers and trees occurring throughout the Old World (OW) tropics, subtropics and warmer temperate regions (Hauenschild et al. 2016; Medan \& Schirarend 2004; POWO 2019). Leaves are typically triplinerved, stipules spinose, inflorescences cymose and fruits drupaceous (Medan \& Schirarend loc. cit.). The fruits of almost all species could be edible (Latiff 1991), and jujube (Ziziphus jujuba Mill.) and ber (Z. mauritiana Lam.) are grown commercially. The genus was included in the morphologically heterogeneous Zizipheae Brongn. (Brongniart 1843, as "Zizypheae") by Hooker (1862), Weberbauer (1895) and Suessenguth (1953). Zizipheae however is predated by Paliureae Reiss. ex Endl. as noted by Schirarend \& Olabi (1994), which is the currently accepted name for the tribe that includes Ziziphus. An analysis of $r b c L$ and $t m L-F$ sequence data by Richardson et al. (2000) confirmed the placement of Ziziphus into Paliureae. Morphological differences between Old World (OW) and New World (NW) species had been reported by several authors (listed by Islam \& Simmons 2006) and an analysis of ITS, 26S rDNA and $t r n L-F$ data by Islam \& Simmons (op. cit.) revealed that the genus was not monophyletic, with OW and NW species belonging to separate lineages. An additional analysis of trmL-F and ITS sequence data by Hauenschild et al. (2016) further supports that the genus Ziziphus as previously defined is not monophyletic and NW species have subsequently been reattributed to the genera Sarcomphalus P.Browne in Paliureae and Pseudoziziphus Hauenschild (op. cit.) in Rhamneae Hook.f. emend. J.E.Richardson (Richardson et al. 2000).
Ziziphus is found across diverse habitats, from savanna-adapted species such as Z. mucronata Willd., widely distributed in the grasslands of Africa (GBIF 2019), to rainforest endemics like most of the species studied here. The genus displays a range of morphological adaptations to these environments: spiny shrubs occurring in xeric shrublands such as Z. spinachristii (L.) Desf. (GBIF 2019), unarmed rainforest trees to $25 \mathrm{~m}$ tall such as $Z$. angustifolia (Miq.) Hatus. ex Steenis, widely distributed in South-East Asia, and armed rainforest woody climbers like most species studied here. Whether functional traits reflect habitat adaptations is part of ongoing work, in particular whether traits such as spinescence reflect a response adaptation to a biome or have facilitated entrance into the biome (Rickenback et al. in prep.). The centre of both the distribution and evolution of Ziziphus seems to be SE Asia (Liu \& Cheng 1995); c. 50 species occur in Asia as opposed to c. 15 in Africa (GBIF 2019). Preliminary genus-level studies also suggest the origin of the genus may have been Asian (Rickenback et al. in prep.). This is consistent with the conclusions of Richardson et al. (2004) who also noted good representation of sister taxa in the Late Eocene-Miocene of North America and Eurasia, suggesting a Laurasian origin for this group followed by more recent migration to Africa. Despite being widely distributed, questions remain around the age, dispersal and morphological adaptations of the genus. Ziziphus is especially diverse in Malesia with over 25 currently accepted species (POWO 2019). Most of the c. $15 \mathrm{SE}$ Asian genera of Rhamnaceae have yet to be revised, although a synopsis of Smythea (Cahen \& Utteridge

\footnotetext{
Accepted for publication 2 April 2021. Published online 10 November 2021

1 Royal Botanic Gardens, Kew, Richmond, Surrey, TW9 3AE, UK. e-mail: d.cahen@kew.org

2 School of Geosciences, University of Edinburgh, Edinburgh, EH9 3JN, UK.

3 Royal Botanic Garden Edinburgh, 20A Inverleith Row, Edinburgh, EH3 5LR, UK.
} 
2018), Gouania (Cahen et al. 2020) and a key to the Bornean species of Ventilago (Cahen \& Utteridge 2017) were recently completed.

In Borneo, no complete taxonomic treatment of Ziziphus has been published, although checklists for the island (Merrill 1929; Masamune 1942) and the Mount Kinabalu area (Beaman \& Anderson 2004) are available, with Merrill listing five species, of which one is excluded in this revision (Z. elmeri Merr. established here as a synonym of Colubrina beccariana Warb.), Masamune listing 11 species, of which Z. elmeri again is excluded here, and Beaman \& Anderson listing eight, of which six are accepted here (the other two, Z. cupularis Suess. \& Overkott and "Ziziphus indet." [Clemens $\mathcal{E}$ Clemens 27375], are synonyms of species also included in their list). The most complete overview of Ziziphus species occurring in Borneo was restricted to Sabah and Sarawak (Schirarend 1995). It includes a detailed account of $Z$. angustifolia and recorded seven climbing species in the key only. Borneo is the island with the greatest known diversity of Ziziphus species in the world with 13 species recognised in this revision. Despite this, Ziziphus oenopolia (L.) Mill. and Z. mauritiana Lam., otherwise widespread in Malesia are not known to have been reported on the island. Many of the species occurring in Borneo have a small distribution range: five are endemic to the island (Z. bormeensis Merr., Z. cuspidata sp. nov., $Z$. domatiata sp. nov., Z. puberula sp. nov. and Z. ridleyana Rasingam \& Karthig.) and four are restricted to the Philippines, Borneo and Sulawesi (Z. crebrivenosa C.B.Rob., Z. cumingiana Merr., Z. havilandii Ridl. and Z. suluensis Merr.). The area surrounding Mount Kinabalu is particularly diverse with nine species recorded for Ranau: Z. angustifolia, Z. bomeensis (including two local endemic varieties: Z. borneensis var. kinabalui Suess. and Z. borneensis var. velutina var. nov.), Z. calophylla Wall., Z. crebrivenosa, Z. cumingiana, Z. cuspidata, Z. havilandii, Z. horsfieldii Miq. and $Z$. suluensis.

The taxonomy of Ziziphus for Borneo is revised here, three new species and two new varieties are described. In addition, four new synonyms are established within the genus and $Z$. elmeri a tree species with pinnate venation, is placed here as a synonym of Colubrina beccariana.

\section{Material and Methods}

Herbarium specimens from $\mathrm{K}$ and $\mathrm{K}-\mathrm{W}$ were studied. Additional specimen images from A, B, BR, BRI, C, CAS, CM, E, F, FI, GH, HBG, L, M, MEL, NY, P, PH, $\mathrm{S}$, SING, U, UC, US were examined. All cited specimens or their image were seen unless specified. Most of the available material from the island was collected in Sabah by the Sandakan Forest Research Centre (SAN; c. $25 \%$ of studied sheets) and Sarawak by the Kuching Department of Forestry (SAR; c. 15 $\%$ ). An alphabetical index to all numbered examined collections from Borneo is given at the end of the paper (Appendix 1). Material was examined under a Zeiss Stemi 1000 binocular microscope at magnifications of up to $\times 350$. Leaf anatomy terms used are from Hickey (1979). Hair density terms are defined as follows: sparse when hairs are scattered enough not to touch when pressed towards each other, abundant when hairs are close enough to touch if pressed towards each other, dense when hairs are so close to each other that they hide the surface of the organ they grow on. Other morphology terms follow Beentje (2010). Measurements were made on material available at $\mathrm{K}$ and for specimens collected in Borneo only, except for type specimens of species occurring there but collected outside the island. To facilitate species identification, average measurements are sometimes used in the Key to species. Averages were calculated by recording measurements in spreadsheets and excluded the least developed, distal leaves. Habitat, elevation, vernacular names and phenological information are also indicated here for Borneo records only; and only specimens from Borneo are listed in the specimens examined. Habitat names used are from Ecoregions 2017 (Dinerstein et al. 2017). Collection locality coordinates used for species distribution maps were retrieved from label information for Borneo specimens and from GBIF (2019) for specimens collected outside the island. GeoCat (Bachman et al. 2011) was used to calculate Extents of Occurrence (EOO) and protected areas were located using the World Database on Protected Areas online interface (IUCN \& UNEP-WCMC 2019).

\section{Key morphological characters}

\section{Leaves}

Ziziphus species have triplinerved leaves, with three main veins, the outer two of which branch off the midrib at the base of the lamina and run in convergent arches to the leaf apex ("basal, perfect, acrodromous venation" sensu Hickey 1979) (Fig. 2B). Leaves also present \pm closely and regularly spaced, scalariform, transverse veins between the main veins (Fig. 3B). In addition, most species in Borneo have strong marginal veins branching off the outer main veins towards the leaf margin (Fig. 2B). Minute callosities c. $1 \mathrm{~mm}$ long are distributed along the leaf margin and when the margin is serrated each serration is topped by such a callosity (Fig. 1G). Examining leaves is enough to identify most Borneo Ziziphus plants to species. Particularly useful characters for identification include: leaf size (to about $30 \mathrm{~cm}$ long in the two tree species $Z$. angustifolia and Z. ridleyana vs $<20 \mathrm{~cm}$ in the climbing species; and among climbers, usually $>12 \mathrm{~cm}$ in $Z$. crebrivenos $a$ and Z. kunstleri vs usually $<9 \mathrm{~cm}$ in other species; the 
smallest leaves are in Z. havilandii, usually $2.5-5.5$ $\mathrm{cm}$ ), the presence of many dark glands, appearing as black spots, covering the abaxial surface (present in $Z$. havilandii and Z. suluensis, absent in all other species), the number of strong veins branching off the outer main veins towards the leaf margin (absent in Z. calophylla, Z. havilandii and Z. suluensis; c. 4 on either side in Z. domatiata, c. 5 in Z. cumingiana var. cumingiana, c. 6 in Z. cuspidata and Z. horsfieldii, c. 8 in $Z$. borneensis except $>15$ in var. ranggam, $>10$ in Z. puberula, $>20$ on either side in Z. angustifolia, $Z$. crebrivenosa, Z. kunstleri and Z. ridleyana) and the presence of hairs on the abaxial lamina surface, main veins excluded (hairy in Z. borneensis, Z. cumingiana var. cumingiana, Z. cuspidata, Z. crebrivenosa, Z. kunstleri and $Z$. ridleyana vs glabrous to subglabrous in other species). The prominence, closeness and branching of transverse veins provide additional characters for identification (e.g. clearly raised, spaced by c. $5 \mathrm{~mm}$ from each other and often branching in Z. kunstleri; barely raised, spaced by c. $1 \mathrm{~mm}$ from each other and unbranched in Z. calophylla).

\section{Inflorescences and flowers}

All Borneo Ziziphus species present a typical Rhamnaceae flower, with five valvate, adaxially keeled calyx lobes, five small hooded petals each enclosing a stamen, and a fleshy nectar disk (Fig 2G \& Fig. 4G). In the Ziziphus of Borneo, the disk surrounds a partially immersed ovary and is 10-pitted (Fig. 2H \& Fig. 4H), except in $Z$. angustifolia and $Z$. ridleyana where the disk is rugose and appears \pm 20 -pitted. Ziziphus angustifolia and $Z$. ridleyana flowers also differ in having $2-4$ style arms vs 2 in all other species. These flower characters, along with the unarmed tree habit (all other species in Borneo are spiny climbers), could indicate that the two species are in a separate clade. Otherwise, flowers appear relatively consistent morphologically. They are arranged in cymes, which can either be subsessile and almost fascicle-like (in Z. angustifolia, Z. borneensis, Z. cumingiana and Z. ridleyana) or clearly pedunculate (all other species) (Fig. 2F \& Fig. 4F). Ziziphus kunstleri is distinctive in the leaves subtending the cymes being distinctly smaller and narrower than other leaves, falling soon, and the inflorescences ultimately appearing to be arranged in panicles. Leaves subtending the cymes also tend to fall soon in $Z$. calophylla and Z. suluensis but they are not morphologically distinct from other leaves; the leaves subtending the cymes seem more or less persistent in all other species. Bracteoles at the base of pedicels are present and are narrowly triangular, entire to laciniate and $1-5 \mathrm{~mm}$ long (Fig. 2F).

\section{Fruit}

Fruits are particularly useful for the identification of Ziziphus species in Borneo and provide the most diagnostic characters along with the leaves. All are single-stoned and fleshy (drupes), but they vary in size, shape and pubescence. Those of Ziziphus crebrivenosa are unique in being covered in raised, blister-like lenticels. Ziziphus cumingiana is recognised in the small fruits, c. $7 \mathrm{~mm}$ long (vs at least $10 \mathrm{~mm}$ long in all other Borneo Ziziphus species). Only three species have glabrous fruits: Z. cumingiana, Z. cuspidata (Fig. 2L) and Z. domatiata (Fig. 3E). Ziziphus horsfieldii fruits are characteristically obovoid (wider towards apex) and c. $1.1 \times 1.1 \mathrm{~cm}$. Except for $Z$. crebrivenosa, which has fruits with raised lenticels, $Z$. borneensis and Z. puberula are the only other species of the genus in Borneo with fruits that are ellipsoid, $>1.5 \times$ longer than wide, and $>2 \mathrm{~cm}$ long (vs globose to obovoid, $<1.5 \times$ longer than wide, or, if ellipsoid, then $<2 \mathrm{~cm}$ long) (Fig. 4J).

\section{Taxonomic Treatment}

\section{Key to Ziziphus species in Borneo}

1. Trees, unarmed. Leaves long, to $31 \mathrm{~cm}$ long. Inflorescences axillary, subsessile fascicle-like cymes; style arms $2-4 \ldots \ldots . .2$

- Climbers, spiny. Leaves smaller, not exceeding $20 \mathrm{~cm}$ in length. Inflorescences axillary fascicle-like cymes, pedunculate cymes or panicles; style arms 2 [note: flowers not known for Z. domatiata] . .......... 3

2. Leaves and branchlets subglabrous, calyx lobes c. $2 \mathrm{~mm}$ long. (Widely distributed from southern Thailand to Solomon

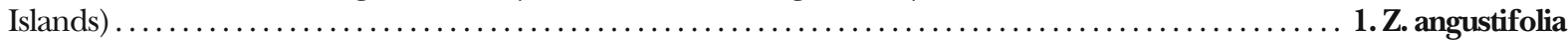

- Leaves and branchlets with a dense reddish-brown indumentum, calyx lobes c. 4 mm long. (Only known from Kuching

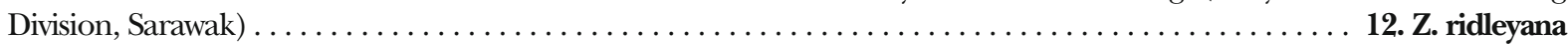

3. Leaves thin-chartaceous, usually hairy along the main veins abaxially only; margin widely and weakly crenate with a tooth and hairs inserted by the sinus of each crenation; venation including the smallest veins evenly dark red when dry, contrasting strongly with the paler colour of the lamina surface. Inflorescences subsessile fascicle-like cymes; pedicels and outside of flowers sparsely hairy. Fruits small, c. $0.7 \mathrm{~cm}$ long, obovoid (wider towards apex), glabrous $\ldots \ldots \ldots \ldots \ldots \ldots \ldots \ldots \ldots \ldots \ldots \ldots \ldots \ldots \ldots \ldots \ldots \ldots$. cumingiana var. cumingiana

- Leaves chartaceous to subcoriaceous, glabrous to densely hairy; margin entire to finely serrate, not widely and weakly crenate; venation colour various. Inflorescences subsessile fascicle-like cymes, pedunculate cymes or 
paniculate; pedicels and outside of flowers abundantly to densely hairy. Fruits $1-3 \mathrm{~cm}$ long, globose, obovoid

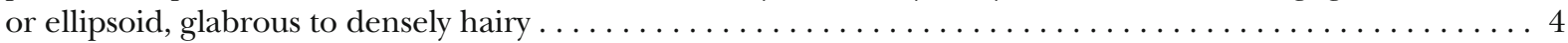

4. Leaves with usually only the three main veins clearly visible, strong veins branching off outer main veins towards the leaf margin usually lacking; intramarginal vein running along the leaf margin present, faint but distinct; transverse veins that join the main veins closely and regularly spaced by c. $1 \mathrm{~mm}$ from each other; longitudinal venules between the transverse veins indistinct. Fruits densely hairy $\ldots \ldots \ldots \ldots \ldots \ldots \ldots \ldots \ldots \ldots \ldots \ldots \ldots \ldots$

- Leaves with strong veins branching off outer main veins towards the leaf margin present; intramarginal vein running along the leaf margin present or absent; transverse veins that join the main veins closely and regularly spaced or not, spaced by $1-5 \mathrm{~mm}$ from each other; longitudinal venules between the transverse veins indistinct to conspicuous. Fruits glabrous to densely hairy $\ldots \ldots \ldots \ldots \ldots \ldots$

5. Leaves with many dark glands on abaxial surface (appearing as black spots), lamina usually asymmetric, chartaceous to subcoriaceous, usually $<8 \mathrm{~cm}$ long; leaf base mostly rounded to subcordate. Inflorescences with

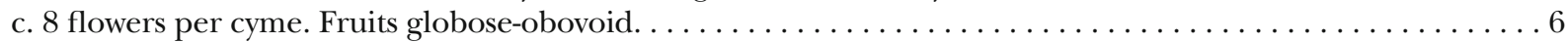

- Leaves with no to many dark glands on abaxial surface, lamina usually \pm symmetric, subcoriaceous, on average c. $11 \mathrm{~cm}$ long; leaf base mostly wide-cuneate to rounded. Inflorescences with c. 16 flowers per cyme. Fruits usually ellipsoid-obovoid $\ldots \ldots \ldots \ldots \ldots \ldots \ldots \ldots \ldots \ldots \ldots \ldots \ldots \ldots \ldots \ldots \ldots \ldots \ldots$. Z. calophylla

6. Leaves chartaceous, usually widest near base, narrow ovate, $(1.0-) 2.5-5.5(-6.5) \times(0.5-) 1.2-2.5(-3.5) \mathrm{cm}$, indumentum dense on distal branchlets at fruiting. Fruits $(0.4-) 0.9(-1.5) \times(0.3-) 0.8(-1.3) \mathrm{cm} \ldots \ldots$. . Z. havilandii

- Leaves chartaceous-subcoriaceous, usually widest near middle, elliptic-oblong, $(4.5-) 8(-13) \times(1.9-) 3.5(-5.2) \mathrm{cm}$, indumentum sparse to abundant on distal branchlets at fruiting. Fruits $1.2-1.5 \times 0.9-1.5 \mathrm{~cm} \ldots \ldots \ldots$ 13. Z. suluensis

7. Leaves usually $>12 \times 6 \mathrm{~cm}$, strong veins branching off outer main veins towards the leaf margin $>20$ on either

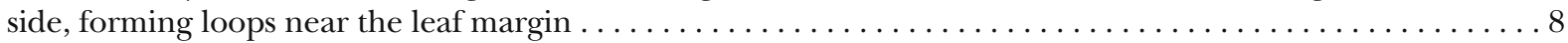

- Leaves usually $<9 \times 4 \mathrm{~cm}$, strong veins branching off outer main veins towards the leaf margin usually $<12$ on either side (except $>15$ in Z. borneensis var. ranggam and often $>12$ in Z. puberula), forming loops near the leaf margin or ascending and gradually diminishing and not forming conspicuous loops . . . . . . . . . .

8. Fruits covered in raised, blister-like lenticels. Branchlets with conspicuous, raised lenticels. Transverse veins between main veins usually joining main veins without branching; longitudinal venules between transverse veins visible but not clearly raised. Cymes subtended by usually persistent leaves, not much smaller and narrower than other leaves, the flowers remaining arranged in pedunculate cymes subtended by leaves $\ldots \ldots \ldots \ldots \ldots \ldots \ldots \ldots \ldots \ldots \ldots$ 4. Z. crebrivenosa

- Fruits covered in reddish hairs, lenticels not present. Branchlets with superficial lenticels concealed by the dense, reddish indumentum. Transverse veins between main veins usually branching; longitudinal venules between transverse veins conspicuous, clearly raised. Cymes subtended by fugaceous leaves, distinctly smaller and narrower than other leaves, the flowers usually ultimately arranged in leafless panicles $\ldots \ldots \ldots \ldots \ldots \ldots \ldots \ldots \ldots \ldots \ldots \ldots \ldots$ Z. kunstleri

9. Fruits ellipsoid, $>1.5 \times$ longer than wide, usually $>2 \mathrm{~cm}$ long, densely hairy. Inflorescences subsessile fasciclelike cymes or pedunculate cymes. Leaves usually $>7 \times 3 \mathrm{~cm}$; strong veins branching off outer main veins towards

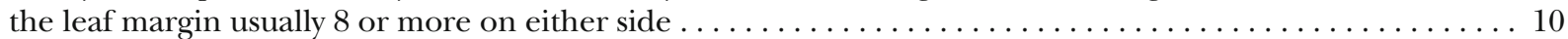

- Fruits globose to obovoid, $<1.5 \times$ longer than wide, usually $<2 \mathrm{~cm}$ long, glabrous to densely hairy. Inflorescences pedunculate cymes. Leaves usually $<7 \times 3 \mathrm{~cm}$; strong veins branching off outer main veins towards the leaf margin usually

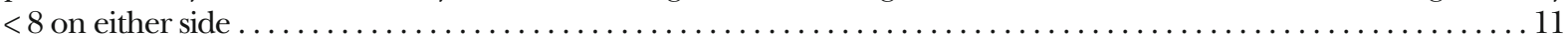

10. Inflorescences subsessile fascicle-like cymes, peduncles rudimentary, $<4 \mathrm{~mm}$ long if developed. Indumentum on distal branchlets of hairs mostly c. $0.5 \mathrm{~mm}$ long, often $>1 \mathrm{~mm}$ long. Strong veins branching off outer main veins towards the leaf margin c. 8 on either side (except $>15$ in Z. bormeensis var. ranggam), rarely forming clear loops with each other, all reaching a usually well-defined intramarginal vein running along the leaf margin; lamina densely hairy abaxially, soft to touch due to the hairs, hairs $\mathrm{c} .1 \mathrm{~mm}$ long $\ldots \ldots \ldots \ldots \ldots \ldots \ldots \ldots \ldots \ldots \ldots \ldots \ldots \ldots \ldots \ldots \ldots \ldots \ldots \ldots \ldots \ldots$. Z. borneensis

- Inflorescences pedunculate cymes, peduncles 3-10 mm long. Indumentum on distal branchlets of very short hairs, $0.1 \mathrm{~mm}$ long. Strong veins branching off outer main veins towards the leaf margin $>10$ on either side, ascending and usually forming loops near the margin, with no clear intramarginal vein running along the leaf margin; lamina subglabrous abaxially except along larger veins, hairs minute, $0.1 \mathrm{~mm}$ long ........... 11. Z. puberula sp. nov.

11. Leaf lamina subglabrous abaxially except along larger veins. Fruits glabrous or densely hairy, subglobose to obovoid, usually $<1.5 \mathrm{~cm}$ long. Leaves widest near base, narrow ovate; apex usually acuminate; base

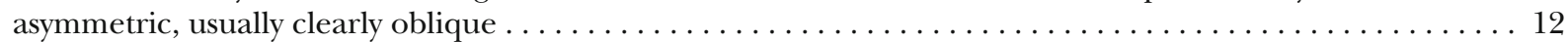

- Leaf lamina with abundant hairs abaxially, rarely subglabrous. Fruits glabrous, globose to ellipsoid, usually $>1.5 \mathrm{~cm}$ long. Leaves usually widest near middle, elliptic; apex usually acute to attenuate, rarely acuminate; base usually symmetric ..... . $\ldots \ldots \ldots \ldots \ldots \ldots \ldots \ldots \ldots \ldots \ldots \ldots \ldots \ldots \ldots \ldots \ldots \ldots \ldots \ldots \ldots \ldots \ldots \ldots \ldots \ldots$. cuspidata sp. nov.

12. Fruits glabrous, subglobose, ripening creamy-grey. Leaf strong veins branching off outer main veins towards the margin c. 4 on either side, often less $\ldots \ldots \ldots \ldots \ldots \ldots \ldots \ldots \ldots \ldots \ldots \ldots \ldots \ldots$ 7. Z. domatiata sp. nov. 
- Fruits densely hairy, obovoid, ripening yellowish-green. Leaf strong veins branching off outer main veins towards the margin c. 6 on either side, rarely $<5 \ldots \ldots \ldots \ldots \ldots \ldots \ldots \ldots \ldots \ldots \ldots \ldots$. horsfieldii

\section{Ziziphus angustifolia (Miq.) Hatus. ex Steenis} (van Steenis 1960: 13). Celtis angustifolia (Miq.) Planch. (Planchon 1873: 186). Solenostigma angustifolium Miq. (Miquel 1861: 412). Type: Indonesia, Sumatra, Priaman, [collector unknown] HB 2501 (lectotype, selected here: L [L 0013794]; paralectoype: L [L 0931291]).

Celtis grewioides Warb. (Warburg 1891: 287). Ziziphus grewioides (Warb.) L.M.Perry (1954: 595). Type: Papua New Guinea, Hatzfeldthafen, s.d., Warburg 20810 (lectotype, selected here: B [B 10 0295710]; isolectotype: L [L 0013795]).

Ziziphus inermis Merr. (Merrill 1905: 37). Type: Philippines, Luzon, Rizal, Bosoboso, May 1905, Ahern's collector Forestry Bureau No 3075 (lectotype, selected here: NY [00415112]; isolectotype: US [00094330]). Ziziphus forbesii Baker f. (Baker 1923: 10). Type: Papua New Guinea, Mt Gawada, $2500 \mathrm{ft}$ [750 m], Forbes 910 (lectotype, selected here: BM [BM000838632]; isolectotypes: BRI [BRI-AQ0317636], FI [FI008653], L [L 0013796], MEL [MEL 567838]).

Tree, to at least $25 \mathrm{~m}$ high, unarmed, girth to $1.5 \mathrm{~m}$ in diam.; bole \pm straight, to at least $15 \mathrm{~m}$ high, buttresses sometimes present, low, $1 \times 1(-1.5) \mathrm{m}$. Bark usually greyish-brown, smooth, not peeling, to at least $12 \mathrm{~mm}$ thick; lenticels visible, in longitudinal rows, yellowishbrown, inner bark yellowish or pale pink grading into orange near cambium, to at least $2.5 \mathrm{~mm}$ thick; cambium pink, orange or red, to at least $1.25 \mathrm{~mm}$ thick. Sapwood yellowish-brown, hard; heartwood dark brown, hard. Branchlets terete, with longitudinal striations and visible lenticels, hairs absent to sparse (dense), hairs short, c. $0.1 \mathrm{~mm}$ long, appressed. Stipules not transformed into spines, early deciduous, narrowly triangular, c. $2 \mathrm{~mm}$ long, densely hairy. Leaves weakly discolorous, drying greenish-brown, blade \pm symmetric, (narrow) elliptic-oblong, $7.5-22.5 \times 2.5-8.6 \mathrm{~cm}$, chartaceous to subcoriaceous, apex attenuate to acuminate, base (cuneate - ) obtuse to rounded, \pm symmetric, margins usually subentire, sometimes clearly serrate, each serration topped by a minute protruding callosity that dries darker than the lamina, c. $0.1 \mathrm{~mm}$ long; primary veins 3 , impressed adaxially, raised abaxially, hairs sparse (- abundant) along primary veins abaxially, c. $0.2 \mathrm{~mm}$ long, \pm appressed, reddish some whitish; strong marginal veins coming off the outside of the two outer main veins $>20$ on either side, all ending in a distinct intramarginal vein running along the leaf margin, angle of divergence with outer main veins c. $65^{\circ}$; transverse veins between the main veins conspicuous, coming off midrib at $\mathrm{c}$. $90^{\circ}$, raised (readily felt by touch), spaced by $(2-) 4$ (10) $\mathrm{mm}$ from each other; higher order reticulations visible; lamina glabrous (- abundantly hairy) abaxially; no domatia visible; petiole subterete, 5 - $12 \mathrm{~mm}$ long, glabrous. Inflorescence of axillary short-pedunculed, almost fascicle-like cymes, often branched, usually c. as long as subtending leaf's petiole, 6 - 12 flowers in each cyme; pedicels to $2-3 \mathrm{~mm}$ long, hairs dense; bracteoles entire, narrowly triangular, c. $1 \mathrm{~mm}$ long, hairy. Flower hypanthium densely hairy on the outer surface; sepals triangular, c. $2 \mathrm{~mm}$ long, glabrous and keeled adaxially; petals clawed, c. $1.4 \mathrm{~mm}$ long, obcordate; stamen filaments flat, subulate, c. $1.2 \mathrm{~mm}$ long, anthers c. $0.4 \mathrm{~mm}$ long, exceeding petals; nectary disk pentagonal, rugose, appearing \pm 20 pitted, glabrous, annulus strongly raised and sheathing style; style arms $(2-) 3(-4)$, c. $0.5 \mathrm{~mm}$ long, diverging, not expanding at apex, glabrous ovary partially immersed. Fruit a drupe, ripening yellowishgreen, pinkish or red, $(1.3-) 1.6(-1.9) \times(0.8-) 1.1$ (1.5) $\mathrm{cm}$, obovoid [wider towards apex], glabrous; fruiting pedicels c. $3-6 \mathrm{~mm}$ long; hypanthium remains annular at base of fruit.

DISTRIBUTION. Brunei, Indonesia (Java, Kalimantan, Maluku, Sulawesi, Sumatra, West Papua), Malaysia (Peninsular Malaysia, Sabah, Sarawak), Myanmar, Papua New Guinea, Philippines (Biliran, Leyte, Luzon, Masbate, Mindanao, Mindoro, Palawan, Samar), Solomon Islands, Thailand. Map 1.

ADDITIONAL SPECIMENS EXAMINED. BRUNEI. BELAIT: Labi F.R., 29 June 1935, Ja'amat KEP 39641 (K); TUTONG: Upstream from Belabau on Tutong R., $20 \mathrm{~m}, 18$ March 1990, Coode et al. 6318 (E, K, L); Rambai, Bukit Bahak Ridge. Vicinity of LP338A, 300 m, 14 Dec. 1991, Coode et al. 7052 (K, L); INDONESIA. BORNEO: Boekit Tjihan [Bukit Cehan], 10 Dec. 1898, Amdjah 314 (K, L); EAST KALIMANTAN, P.T. ICTI, Gunung Meratus, 22 Nov. 1997, Ambriansyah AA 2155 (E, K, L); ibid., 20 Feb. 1998, Ambriansyah E $\mathcal{F}^{2}$ Priyono AA 2187 (E, K); E. Kutei, Sg. Menubar Region, 5 m, 7 June 1951, Kostermans 5032 (K, L); Loa Haur, W of Samarinda, 40 m, 13 May 1952, Kostermans 6917 (K, L); SOUTH KAlimantan, Djaro Dam. c. $10 \mathrm{~km}$ NE of Muara Uja, c. $1^{\circ} 50$ 'S $115^{\circ} 40^{\prime} \mathrm{E}, 70 \mathrm{~m}, 16$ Oct. 1972, de Vogel 1667 (K, L); ibid., 6 March 1973, de Vogel 2196 (L); WEST KALIMANTAN, Sintang. Bukit Baka National Park. Along bank of Sungai Ella, $100 \mathrm{~m}$ NE of camp, 0³8'S 112¹7'E, 13 Oct. 1993, Church et al. 14 (K, L); MALAYSIA. SABAH: BELURAN, W of Lake Sg. Namatoi, $\pm 1300 \mathrm{ft}$ [400 m], 12 June 1978, Madani SAN 88843 (L); KENINGAU, Ulu Sg. Mantuluk, Witti Range area, 16 Jan. 1986, Krispinus SAN 113272 (K, L); 


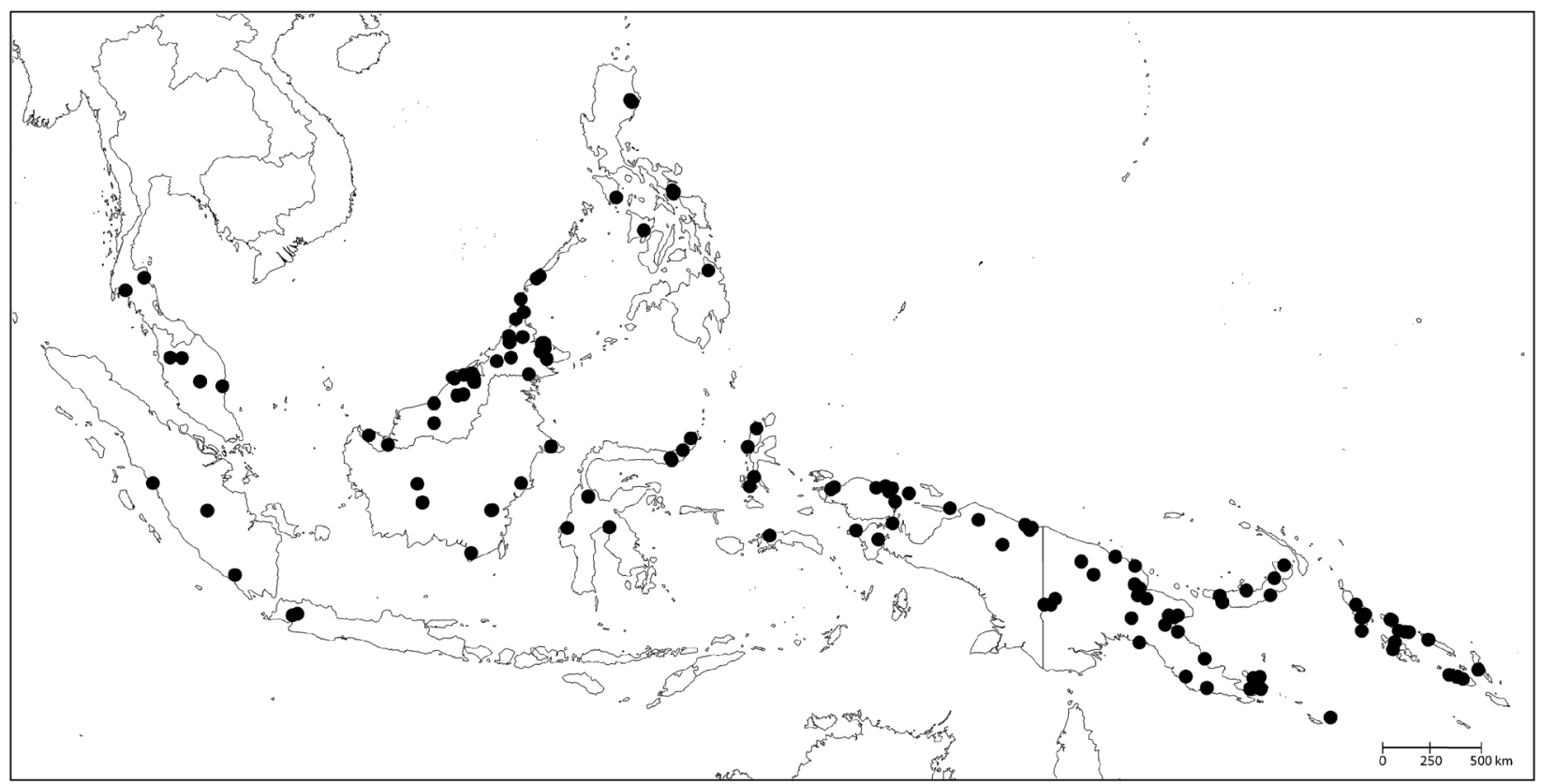

Map 1. Distribution of Ziziphus angustifolia (•).

KInABATANGAN, Supu F.R., Elopura, edge of Kaboi R., 100' [30 m], 12 Oct. 1938, Puasa NBF 10106 (K, L); KOTA BELUD, Kampung Melangkap Tomis, 2 km dari Melangkap Tomis, 8 Nov. 1995, Lugas 1229 (K); Len Hin Logging Area, Mile 68 Kudat-Kota Belud Road, \pm 680 ft [200 m], 14 Nov. 1963, Mikil SAN 40341 (L); KUDAT, Labuan F.R., Penangsoo, 40 feet [10 m], 27 Aug. 1937, Apostol 7678 (K, L); Banguey [Banggi] Island, July - Sept. 1923, Castro Ẽ Melegrito 1468 (K); LAHAD DATU, Sg. Taliwas, $\pm 500 \mathrm{ft}[150 \mathrm{~m}], 20$ Nov. 1963, Ambullah 37187 (K, L); RANAU, Tenompok, $5000 \mathrm{ft}$ [1500 m], 10 Nov. 1931, Clemens $\mathcal{E}$ Clemens 27051 (L); Kampung Bundu Tuhan, Kampung Himbaa, 19 Dec. 1993, Soibeh 627 (K); SANDAKAN, Lahad Datu road, 50 ft [15 m], 25 July 1978, Arshid SAN 88621 (L); Lagsikan Forest Reserve, 300 ft [90 m], 3 Jan. 1953, Bukah A 3418 (K, L); Mamanjang Agriculture Station, 11 July 1973, Madani SAN 77372 (K, L); Segaliud Lokan, 12 Oct. 1988, Majawat et al. SAN 102438 (K); Lungmanis Timber camp, 9 Aug. 1962, Mikil SAN 31565 (K, L); Sapagaya, 50 ft [15 m], 15 June 1937, Puasa 7201 (L); Elopura Forest Distr., Suan Lamba, 100 ft [30 m], 7 Oct. 1939, Puasa Ẽ Enggoh 10623 (K, L); Ladang Fico Bilit, 16 Jan. 1985, Sundaling SAN 107497 (K); TAWAU, Kalabakan prop. V.F.R., $\pm 250 \mathrm{ft}[75$ m], 16 Dec. 1961, MeijerSAN 27921 (K, L); Bukit Gemok F. Res., 11 June 1997, Sundaling et al. SAN 135259 (K, L); TENOM, Pa'al, Gibot SAN 64335 (K, L); SARAWAK. Kelinkang [Kelingkang] Range, 400 m, 14 Oct. 2001, Hazlinah et al. S. 86696 (L); BINTULU, Segan Forest Reserve, 16 Sept. 1972, Chai S.31703 (K, L); ibid., 26 Nov. 1961, Paie S.15569 (K, L); Sg. Bunut, Maying, Kakus, Tatau, 500 m, 6 Oct. 1985, Paie S.50173 (K, L); KAPIT, Pelagus, 50 m, 10 July 1979, Hock
S.40631 (K, L); KUCHING, Sg. Rayu, Matang, 26 March 1988, Munting E Jugah S.55601 (K); Sampadi F.R. (near road), 26th mile Bau-Lundu road, 650 ft [200 m], 18 June 1968, Paie S.26187 (L); Kubah National Park, Sg. Rayu, 75 m, 21 Sept. 1994, Rantai Eீ Tinjan S.68738 (K); MIRI, Gunong Mulu National Park, limestone hill opposite the National Park Bungalow, 40 m, 11 Oct. 1976, Martin S.38200 (L); Sarawam, Gunong Api, 200 m, 16 Feb. 1966, Chew 1139 (L); Lambir National Park, Ashton's Ecological Plot 1, 21 June 1983, Hock S.46435 (L); Batu Kalulong, near Gunong Pelamau, Ulu Sg. Tutoh, 610 m, 13 April 1997, Julaihi et al. S.76946 (K, L); Ulu Sg, Lubang, Ulu Tinjar, Baram, 320 m, 4 March 1997, Lai et al. S. 75301 (K, L); Bakam, Sg. Jangkang, Lambir National Park, 100 m, 26 Oct. 1983, Mohtar et al. S.47160 (K, L); ibid., 29 Oct. 1983, Mohtar et al. S.47197 (K, L); Ulu Sg. Sekiwa, Btg. Tinjam, Baram, 30 Aug. 1974, Tong S.34959 (L); SAMARAhAN, G. Buri, 18 March 1982, Yii S.44186 (K, L).

HABITAT. Borneo lowland forests; extending to montane rain forests; alt. $0-1500 \mathrm{~m}$.

CONSERVATION STATUS. Least Concern (LC). Ziziphus angustifolia is widely distributed from southern Thailand to the Solomon Islands. It is commonly collected in lowland mixed dipterocarp forests throughout western Malesia and in the forests of New Guinea and Solomon Islands.

PHENOLOGY. Collected in flower June - Nov.; collected in fruit Jan. - Dec.

VERNACULAR NAMES. Ensarai (Iban, fide Coode et al. 7052); Kayu buluh/Kayu labu (Kedayan, fide Church et al. 14 \& Puasa 7201); Merjawai (Iban, fide Coode 
et al. 6318); Mertama (Iban, fide Mohtar et al. S.47160 \& S.47197, Haslinah et al. S.86696); Otoi Paseng (Punan, fide Coode et al. 7052); Pasil-pasil (Bajau Labuk, fide Apostol 7678); Sireh-sireh/Sirih-sirih (Iban, fide Hock S.46435, Munting E Jungah S.55601, Lai et al. S.75301, Tong S.34959, Julaihi et al. S.76946); Tanpahelaue (Merap, Persoon \& Osseweijer 2008). USES. Fruits edible (fide Apostol 7678, Coode et al. 6318 and Sundaling SAN 107497).

NOTES. In Borneo, Ziziphus angustifolia is most like $Z$. ridleyana, the only other known tree species of the genus to occur on the island. Both are unarmed and their leaves have a similar oblongelliptic to oblong-lanceolate shape that can exceed $20 \mathrm{~cm}$ in length. Their venation pattern is similar with three strong main veins converging at the leaf base and apex and a distinct intramarginal vein running along the leaf margin; transverse veins between the main veins are raised and usually wellspaced, by at least $3 \mathrm{~mm}$; reticulations are clearly visible between the transverse veins. Both species also have axillary, subsessile fascicle-like cymes with flowers that can have 3 style arms or more (all other Ziziphus species from Borneo with flowers available for study have 2 style arms). Ziziphus angustifolia differs from $Z$. ridleyana in the subglabrous branchlet and abaxial leaf surfaces (vs densely covered in reddish-brown hairs) and in the smaller flowers (calyx lobes only $2 \mathrm{~mm}$ long in $Z$. angustifolia vs c. $4 \mathrm{~mm}$ in $Z$. ridleyana). The only other Borneo Ziziphus species with axillary, subsessile fascicle-like cymes and fruits are $Z$. borneensis and Z. cumingiana which, apart from being spiny climbers, both differ strongly from Z. angustifolia in leaf and fruit size and shape.

Miquel (1861) lists Priaman and Lubu-alang as localities in the protologue for Solenostigma angustifolium and van Steenis (1960) cites HB 758 (Lubu-alang) [L 0931291] and HB 2501 (Priaman) [L 0013794], both held at L, as syntypes. The specimens are sterile but HB 2501 is less fragmented and selected as the lectotype here. Celtis grewioides (basionym of Ziziphus grewioides), Z. inermis and $Z$. forbesii are all listed as synonyms of $Z$. angustifolia by van Steenis (loc. cit.). This view is accepted here and each is lectotypified: Warburg (1891) cited material from Hatzfeldthafen and the sheet held at Berlin, where Warburg worked in 1891, is selected as the lectotype for Celtis grewioides; the NY sheet of Ahern's collector Forestry Bureau No 3075, cited as the type of Ziziphus inermis by Merrill (1905), is selected as the lectotype rather than the US one because Merrill worked in NY; sheets of Forbes 910, the only collection mentioned by Baker (1923), are available in several institutions and the BM material is selected as the lectotype because it was the most likely to have been examined by Baker.
2. Ziziphus borneensis Merr. (Merrill 1929: 178). Type: Malaysia, Sabah, Sandakan, Oct. - Dec. 1921, Elmer 20149 (lectotype, selected here: UC [UC 228986]; isolectotypes: BR [5289356], CAS [0005256], CM [1372], GH [00051547, 00051548], HBG [HBG510064], K [K000723023], L [L 0551682], M [M-0211798], P [P06790404], PH [PH00029952, PH00029953], SING [SING 0059176], U [U 1541200]).

Woody climber to at least $20 \mathrm{~m}$ long; girth to at least $6 \mathrm{~cm}$ in diam., spiny. Branchlets terete, with longitudinal striations and visible lenticels when surface not hidden by indumentum, sparsely to densely hairy on young parts and distal portions, becoming sparsely hairy to glabrous when mature, hairs variable, usually c. $0.5 \mathrm{~mm}$ long, often $>1 \mathrm{~mm}$ long, straight to curved, spreading to appressed, reddish. Stipules paired on very young shoots, one becoming a persistent recurved spine, (2 -) $3(-5)$ $\mathrm{mm}$ long, the other short-lived, entire, ovate, c. $4 \times 2 \mathrm{~mm}$, hairs dense. Leaves discolorous, drying greenish-brown, blade slightly asymmetric, narrow ovate (- ellipticoblong), (3.6 -) $7(-15.0) \times(1.4-) 3(-5.3) \mathrm{cm}$, chartaceous to subcoriaceous, apex (acute -) attenuate (- acuminate), base (obtuse - ) rounded (- subcordate), often weakly oblique, margins entire (- finely serrate), with minute callosities that dry much darker than the lamina, > 150 on either side, often protruding and c. $0.1 \mathrm{~mm}$ long, margin slightly thickened, hairs usually present along margin; primary veins 3, impressed adaxially, raised abaxially, hairs along primary veins dense on either side of lamina, c. $0.4 \mathrm{~mm}$ long, mostly antrorse, reddish; strong marginal veins coming off the outside of the two outer main veins c. 8 on either side (except $>15$ in var. ranggam), ascending and ending in a distinct intramarginal vein running along the leaf margin (except indistinct in var. kinabalui and var. velutina), angle of divergence with outer main veins c. $45^{\circ}$; transverse veins between the main veins conspicuous, coming off midrib at c. $90^{\circ}$, raised, spaced by c. $1 \mathrm{~mm}$ from each other, usually unbranched, straight (scalariform); higher order reticulations between transverse veins usually barely discernible (except reticulate abaxially, with the longitudinal venules between the transverse veins that join the main veins conspicuous and raised in var. ranggam); lamina subglabrous to densely hairy, always at least hairy along main and transverse veins, soft to touch when densely hairy, hairs c. $1 \mathrm{~mm}$ long, spreading to curved-antrorse, reddish; no domatia visible; petiole slightly dorsiventrally flattened, (2 -) 4 (6) $\mathrm{mm}$ long, hairs dense, indumentum extending to widened base of main veins adaxially. Inflorescence of axillary, subsessile fascicle-like cymes, 2 - 8 (-10) flowers in each cyme; peduncles rudimentary, rarely developed to $4 \mathrm{~mm}$ long; pedicels to $4 \mathrm{~mm}$ long, hairs dense, reddish, c. $0.5 \mathrm{~mm}$ long, mostly spreading to patent; bracteoles entire, narrowly triangular, c. $2 \mathrm{~mm}$ long, 
hairy. Flower hypanthium densely hairy on the outer surface, hairs c. $1 \mathrm{~mm}$ long, appressed-antrorse, reddish; sepals triangular, $1.5-3 \mathrm{~mm}$ long, greenish when fresh, glabrous and keeled adaxially; petals clawed, c. $2.5 \mathrm{~mm}$ long, obcordate, white when fresh; stamen filaments flat, subulate, c. $2 \mathrm{~mm}$ long, pale yellow-green when fresh, anthers c. $0.5 \mathrm{~mm}$ long, enclosed by petals; nectary disk pentagonal, weakly 10-pitted, glabrous, style arms 2, free for c. $1 \mathrm{~mm}$ long, strongly diverging, glabrous; ovary partially immersed, hairs dense. Fruit a drupe, ripening greenish-yellow to red, c. $2.2 \times 1.5 \mathrm{~cm}$, ellipsoid, surface wrinkly when dry, covered in minute reddish hairs < $0.1 \mathrm{~mm}$ long; fruiting pedicels curved, c. $5 \mathrm{~mm}$ long, hypanthium remains caving in at base of fruit.

\section{Key to varieties of Ziziphus borneensis}

1. Leaves long, to $15 \mathrm{~cm}$; strong marginal veins coming off the outside of the two outer main veins $>15$ on either side; venation reticulate abaxially, with the longitudinal venules between the transverse veins that join the main veins conspicuous and raised; intramarginal vein running along the leaf margin very distinct $\ldots \ldots \ldots \ldots \ldots$

$\ldots \ldots \ldots \ldots \ldots \ldots \ldots \ldots \ldots \ldots \ldots \ldots \ldots \ldots \ldots \ldots \ldots \ldots \ldots \ldots \ldots \ldots \ldots$ 2c. Z. borneensis var. ranggam var. nov.

- Leaves shorter, $<11.5 \mathrm{~cm}$; strong marginal veins coming off the outside of the two outer main veins c. 8 on either side; venation not clearly reticulate, transverse veins that join the main veins much stronger than the longitudinal venules between them; intramarginal vein running along the leaf margin indistinct or distinct .

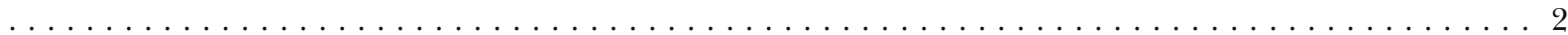

2. Leaves to $>10 \mathrm{~cm}$ long; callosities protruding off a margin that is usually entire in outline; intramarginal vein running along the leaf margin distinct. Branchlet hairs sparse to dense on young parts and distal portions,

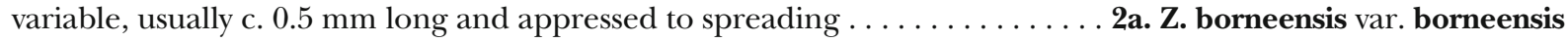

- Leaves < $7.5 \mathrm{~cm}$ long; callosities protruding off a margin that is finely serrate in outline; intramarginal vein running along the leaf margin indistinct. Branchlet hairs dense on young parts and distal portions, longer, c.

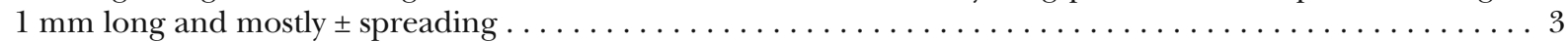

3. Leaf lamina subglabrous abaxially except along larger veins, marginal veins and transverse veins between the

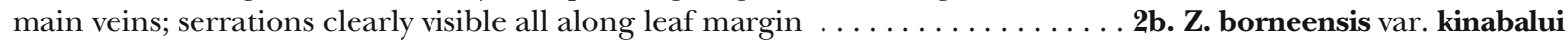

- Leaf lamina densely hairy abaxially on its entire surface; leaf margin serrations clearly visible near leaf apex only $\ldots \ldots \ldots \ldots \ldots \ldots \ldots \ldots \ldots \ldots \ldots \ldots \ldots \ldots \ldots \ldots \ldots \ldots \ldots$ dd. Z. borneensis var. velutina var. nov.

\section{2a. Ziziphus borneensis Merr. var. borneensis}

Branchlets sparsely to densely hairy on young parts and distal portions, hairs variable, usually c. $0.5 \mathrm{~mm}$ long, spreading to appressed. Leaves narrow ovate (- ellipticoblong), (3.6 -) 7 (- 11.4) × (1.4 -) $3(-4.9) \mathrm{cm}$; callosities protruding off a margin that is usually entire in outline; strong marginal veins coming off the outside of the two outer main veins c. 8 on either side, ascending and ending in a distinct intramarginal vein running along the leaf margin. Higher order reticulations between transverse veins barely discernible; lamina densely hairy abaxially on its entire surface. Fig. 1A - E.

DISTRIBUtION. Borneo (Brunei, Kalimantan, Sabah, Sarawak), Endemic. Map 2.

ADDITIONAL SPECIMENS EXAMINED. BRUNEI. BELAIT: Bukit Teraja, path above Rest-house, $4^{\circ} 18^{\prime} \mathrm{N}$ $114^{\circ} 26^{\prime} \mathrm{E}, 310$ m, 4 Dec. 1991, Coode et al. 6900 (K, L); Bukit Sawat, Merangking Buau, $4^{\circ} 32^{\prime} \mathrm{N} 114^{\circ} 35^{\prime} \mathrm{E}$, $40 \mathrm{~m}$, Coode et al. 7688 (K); along edges of unsurfaced road, $20 \mathrm{~km} \mathrm{~S}$ along Labi, open road from Sungai Liang, on logging track, $4^{\circ} 28^{\prime} \mathrm{N} 114^{\circ} 28^{\prime} \mathrm{E}, 90 \mathrm{~m}, 26$ Sept. 1994, Davis et al. 453 (K); Labi Hill Forest Reserve. Compartment 8, next to Sungei Peti, along
Labi Road, $4^{\circ} 30^{\prime} \mathrm{N} 114^{\circ} 28^{\prime} \mathrm{E}, 40 \mathrm{~m}, 13$ Oct. 1989, Forman E B Blewett 862 (K, L); BRUNEI-MUARA: Berakas F.R., 50 ft $[15 \mathrm{~m}$ ], Ashton S.7817 (K, L); TUTONG: Telisai, Bukit Basong along old logging road, 11 Sept. 1996, Kalat et al. BRUN 17809 (K); Ladan Hills Forest Reserve, 125 m, 30 March 1991, Sands et al. 5717 (K, L); INDONESIA. BORNEO: CENTRAL KALIMANTAN, P.T. Pamenang logging concession rd. c. Km 20, $0^{\circ} 02^{\prime} \mathrm{S}$ 11406'E, 23 June 1990, Sidiyasa PBU609 (L); KTC Trumbang Sah Km 96 Katingan R., 1 ${ }^{\circ} 15^{\prime} \mathrm{S} 113^{\circ} 10^{\prime} \mathrm{E}$, 100 m, 4 Feb. 1983, Wiriadinata 3539 (K); EAST KAlimantan, P.T. ITCI, Permanent plot 72-8, $50 \mathrm{~m}$, 2 March 1995, Kessler et al. 775 (K, L); WEST KALIMANTAN, Sintang. Bukit Baka National Park. Panjung butung, $250 \mathrm{~m} \mathrm{~N}$ of camp down Sungai Ella, along bank and near environs, $0^{\circ} 38^{\prime} \mathrm{S} 112^{\circ} 17^{\prime} \mathrm{E}, 315 \mathrm{~m}$, Church et al. 127 (K, L); ibid., E of camp along bank of Sungai Ella and environs, $0^{\circ} 37^{\prime} \mathrm{S} 112^{\circ} 15^{\prime} \mathrm{E}, 290 \mathrm{~m}$, Church et al. 544 (E, L); Amai Ambit, 1893 - 1894, Hallier 3209 (L); Ketapang, Gunung Palung National Park, Cabang Panti Research Site, Trail UB2w20, $1^{\circ} 13^{\prime} \mathrm{S} 110^{\circ} 06^{\prime} \mathrm{E}, 50 \mathrm{~m}, 25$ Oct. 1996, Laman et al. 142 (E, K, L); MALAYSIA. SABAH: Mount Kinabalu, 16 March 1932, Clemens E Clemens 30376 (K); E Coast, s.d., Creagh s.n. (K); Brar Manit, 25 ft [5 m], 12 


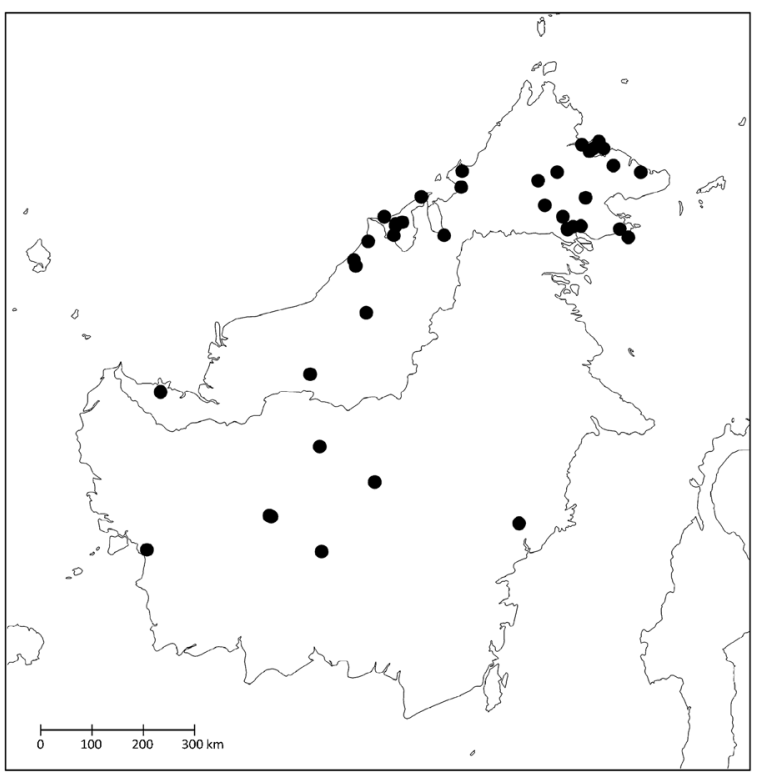

Map 2. Distribution of Ziziphus borneensis var. borneensis (•)

Nov. 1931, Maidi 1534 (K); N Borneo, s.d., Wood 1961 (K), BEAUFORT, Klias, 27 July 1976, Bidin SAN 80728 (K, L); Weston, Sunggau Hill, 20 Feb. 1973, Jumatin 77406 (K, L); BELURAN, Sungai Tahid, 18 Jan. 1985, Amin et al. SAN 67312 (K, L); Sungai Monduring, 28 Oct. 1985, Amin E Donggop SAN 113622 (K, L); KALABAKAN, Block 8 Sabah Foundation unlogged area Seranum, 14 Sept. 1983, Krispinus E Suali SAN 101212 (K, L); Benaword logged areas last 2 years, 18 April 1980, Krispinus E Jimpin SAN 91809 (K, L); Mile 12 Luasong Road, NBT logged area, 23 Sept. 1980, Krispinus E Jimpin SAN 91877 (K, L); Km 28 NBT logged area Kuasong, 22 Aug. 1983, Suali E Pikkoh SAN 96499 (K, L); KINABATANGAN, Keruak, 19 Feb. 1985, Amin $\mathcal{E}$ Maidil SAN 108127 (K); LAHAD DATU, Palum Tambun, c. 150 m, 10 March 1987, Argent et al. 451987 (E); Danum valley and environs, May 1989, Ridsdale et al. CEROL 18 (K, L); Sg. Urik. Ulu Tabin, 750 m, 15 Jan. 1990, Sundaling SAN 129538 (E, K); SANDAKan, Myburgh Province, Sandakan, Oct. - Dec. 1921, Elmer 20361 (K, L, P, U); Bettokan near Sandakan, 5 Aug. 1927, Kloss SFN 19064 (K); Mile 8, top of hill, 13 Jan. 1934, Radin 4191 (K); Sandakan and vicinity, Sept. - Dec. 1920, Ramos 1462 (K, L); Along Jalan Batu 6, Cpt 13, Circle path, Sepilok F.R., $\pm 30 \mathrm{ft}$ [10 m], 29 March 1965, Sam SAN 49929 (K, L); Sg. Mannil, $30 \mathrm{ft}$ [10 m], 17 Feb. 1963, Elleh SAN 34357 (K, L); Tangkulap F.R., 9 Dec. 1985, Gambukas et al. SAN 108026 (K, L); SEMPORNA, Mt Pock F.R., $360 \mathrm{ft}$ (100 m), 28 Nov. 1965, Gansau SAN 54499 (K); TAWAU, E of M. 15, Apas Rd., $80 \mathrm{ft}[25 \mathrm{~m}], 4$ Feb. 1964, Gibot SAN 40901 (K, L); Mile 12, Hap Seng road, 28 March 1979, Krispinus SAN 89801 (K, L); Umas umas, 14 Sept. 1934, Orolfo 4153 (K); TONGOD,
Labuk Sugut, Sungai Tongod, 20 Sept. 1984, Amin et al. SAN 67632 (K, L); SARAWAK: KAPIT, N Tiemai, Ulu Mujong, Balleh, c. 250 m, 20 March 1964, Ashton S.12143 (K); Batu Laga Plateau, Ulu Sungei Benalui, Batang Balui, 960 m, 19 March 1989, Yii S.56905 (K); ibid., 20 March 1989, Yii S.56911 (K); KUCHING, 8 km near Kuching, 19 Sept. 1892, Haviland 1765 (K); LIMBANG, Sg. Sipayan, Bkt. Pagon, 540 m, 3 Aug. 1984, Awa Eं Lee S.47643 (K, L); MIRI, Foot of Lambir Hills, Lambir Hills N.P., 20th mile, 1400 m, 9 Nov. 1976, Paie S.38463 (K, L); Niah F.R., 16 Sept. 1982, Paie Ẽ Dami S.43778 (K, L); Kuala Sungai Sekaloh, Niah National Park, c. 50 ft [15 m], 3 April 1979, Yii S.40106, (K, L).

HABITAT. Borneo lowland and montane rain forests; alt. $0-1400 \mathrm{~m}$.

CONSERVATION STATUS. Least Concern (LC). Although this taxon is endemic and likely declining given the widespread destruction of rainforests in Borneo (Gaveau et al. 2014), it was collected in, or very close to, several protected areas, and its EOO is greater than $450,000 \mathrm{~km}^{2}$. With Ziziphus angustifolia, it is the most collected taxon of Ziziphus in Borneo and is known to have been collected in the following protected areas: Labi Hills (Bukit Teraja) Forest Reserve (IUCN Category Ia), Labi Hills (Luagan Lalak) Forest Reserve (IUCN Category V), Ulu Temburong National Park (IUCN Category II) in Brunei; Bukit Baka Bukit Raya National Park (IUCN Category II) and Gunung Palung National Park (IUCN Category II) in Kalimantan; Kabili Sepilok Virgin Jungle Reserve (IUCN Category not reported), Mount Pock Protection Forest Reserve (IUCN Category Ia), Siaungau Virgin Jungle Reserve (IUCN Category Ia) in Sabah; Lambir Hills National Park (IUCN Category II) and Niah National Park (IUCN Category II) in Sarawak.

PHENOLOGY. Collected in flower in June and Aug. Oct.; collected in fruit Aug. - May.

VERNACULAR NAMES. Kangam Sopuan/Sapuan (Akar fide Maidi 1534 \& Elleh SAN 34357).

USES. Fruits edible, sweet (fide Church et al. 544).

NOTES. Ziziphus borneensis, including all four varieties, is recognised in its cymes being few-flowered, subsessile and fascicle-like (Fig. 1A) and its fruits being hairy and ellipsoid, c. $2.2 \times 1.5 \mathrm{~cm}$. Ziziphus borneensis var. borneensis is most like $Z$. borneensis var. velutina in the branchlets, leaves and flowers most often having a dense reddish indumentum (Fig. 1E) and with the abaxial leaf surface being soft to the touch on account of the dense, soft hairs (Fig. 1D) but differs in the distinct intramarginal vein running along the leaf margin (vs indistinct) (Fig. 1B), the outline of the margin, which is entire (vs serrate near the apex) (Fig. 1C), and the hairs on 
the young parts and distal portions of branchlets usually c. $0.5 \mathrm{~mm}$ long and appressed to spreading (vs c. $1 \mathrm{~mm}$ long and mostly \pm spreading) (Fig. 1E). When compared with other species, this variety is most like $Z$. kunstleri and $Z$. puberula in having hairy, ellipsoid fruits $>2 \mathrm{~cm}$ long but differs from both in the subsessile fascicle-like cymes and fruits. Vegetatively, it differs from $Z$. kunstleri in the transverse veins that join the main veins usually unbranched and closely spaced, by c. $1 \mathrm{~mm}$ from each other and the higher order reticulations between the transverse scalariform veins that join the main veins are barely visible (vs transverse veins usually branched, spaced by c. $5 \mathrm{~mm}$ and with conspicuous, raised longitudinal venules between them) (Fig. 1D). It differs from $Z$. puberula in the conspicuous indumentum of dense hairs $>0.5 \mathrm{~mm}$ long on branchlets, leaves and flowers (vs minute, scarcely visible to the naked eye in $Z$. puberula). It differs from both $Z$. kunstleri and $Z$. puberula in the c. 8 strong marginal veins on either side rarely forming clear loops with each other but all reaching a usually well-defined intramarginal vein running along the leaf margin (vs > 10 strong marginal veins on either side in $Z$. puberula and > 20 in Z. kunstleri, consistently forming clear loops with each other and not joining a well-defined intramarginal vein (Fig. 1A \& B). The strong marginal veins in $Z$. borneensis var. borneensis are reminiscent of $Z$. horsfieldii but the axillary flowers, reddish indumentum and large ellipsoid fruit clearly distinguish the species. Ziziphus cumingiana var. cumingiana also has axillary, fascicle-like cymes but differs in the leaves being thin-chartaceous, with crenate margins, higher order reticulations and well-developed areoles, clearly visible with a hand lens, drying dark red and contrasting strongly with the lamina colour, and the fruits being smaller, c. $7 \times 6 \mathrm{~mm}$, obovoid and glabrous.

Elmer 20149, indicated as the type in the protologue (Merrill 1929), is widely distributed with duplicates available in at least 12 herbaria. The specimen from UC, where Merrill worked from 1924 - 1929, and which is in flower, is selected here as the lectotype.

2b. Ziziphus borneensis var. kinabalui Suess. (Suessenguth 1950). Type: Malaysia, Sabah, Ranau, Tenompok, $5000 \mathrm{ft}[1500 \mathrm{~m}], 14$ March 1932, Clemens E Clemens 30376 (lectotype, selected here: M [M-0211795]; isolectotypes: K [sheet 2, K000723017], L [L 0013798], M [M-0211796]).

Branchlets densely hairy on young parts and distal portions, hairs c. $1 \mathrm{~mm}$ long and mostly \pm spreading. Leaves narrow ovate (- elliptic), (4.2 -) $5.5(-7.5) \times(1.8-) 2.4(-3.1) \quad \mathrm{cm}$; callosities protruding off a margin that is finely serrate in outline, serrations clearly visible all along leaf margin; strong marginal veins coming off the outside of the two outer main veins c. 8 on either side, intramarginal vein running along the leaf margin indistinct; venation not clearly reticulate, transverse veins that join the main veins much stronger than the longitudinal venules between them; lamina subglabrous abaxially except along larger veins, marginal veins and transverse veins between the main veins. Fig. $1 \mathrm{~F}-\mathrm{K}$.

DISTRIBUtION. Borneo (Mount Kinabalu), Endemic. Map 3.

ADDITIONAL SPECIMENS EXAMINED. MALAYSIA. SABAH: RANAU, Tenompok, $5000 \mathrm{ft}$ [1500 m], 14 March 1932, Clemens E Clemens 28839 (K, L).

HABITAT. Borneo montane rain forests; alt. c. 1500 $\mathrm{m}$.

CONSERVATION STATUS. Data Deficient (DD). The variety is only known from a single locality. It thus meets the IUCN Bla criterion for Critically Endangered, but a decline or fluctuation of the population cannot be estimated or inferred. The specimens may have been collected within the Tenompok Protection Forest Reserve (IUCN Category Ia) or Kinabalu National Park and ASEAN Heritage Park (IUCN Category II) where forests appear well preserved in satellite images. The variety is considered here to be Data Deficient because the data are so uncertain that both LC and CR are plausible categories.

PHENOLOGY. Collected in flower in March.

NOTES. Ziziphus borneensis var. kinabalui is most ike $Z$. borneensis var. velutina in the dense reddish indumentum on branchlets, the c. 8 strong marginal veins on either side and the indistinct intramarginal vein running along the leaf margin but differs in the lamina being subglabrous except along main and transverse veins (vs all lamina surface densely hairy) (Fig. 1J) and in the serrations clearly visible all along leaf margin (Fig. 1G \& $\mathrm{H})$.

A sheet of Clemens E Clemens 30376 from M is marked as the holotype, and while this collection is cited in the protologue (Suessenguth 1950), additional material is available at $\mathrm{M}$ and other herbaria. The sheet marked as the holotype is therefore designated here as the lectotype because no specific sheet was indicated in the protologue.

Two sheets of Clemens $\mathcal{E}$ Clemens 30376 are also available at $\mathrm{K}$, but this is a mixed collection: only Sheet 2 (marked "Sheet II") is of this variety of Ziziphus borneensis. Sheet 1 [K000723017] is a specimen of $Z$. havilandii. 

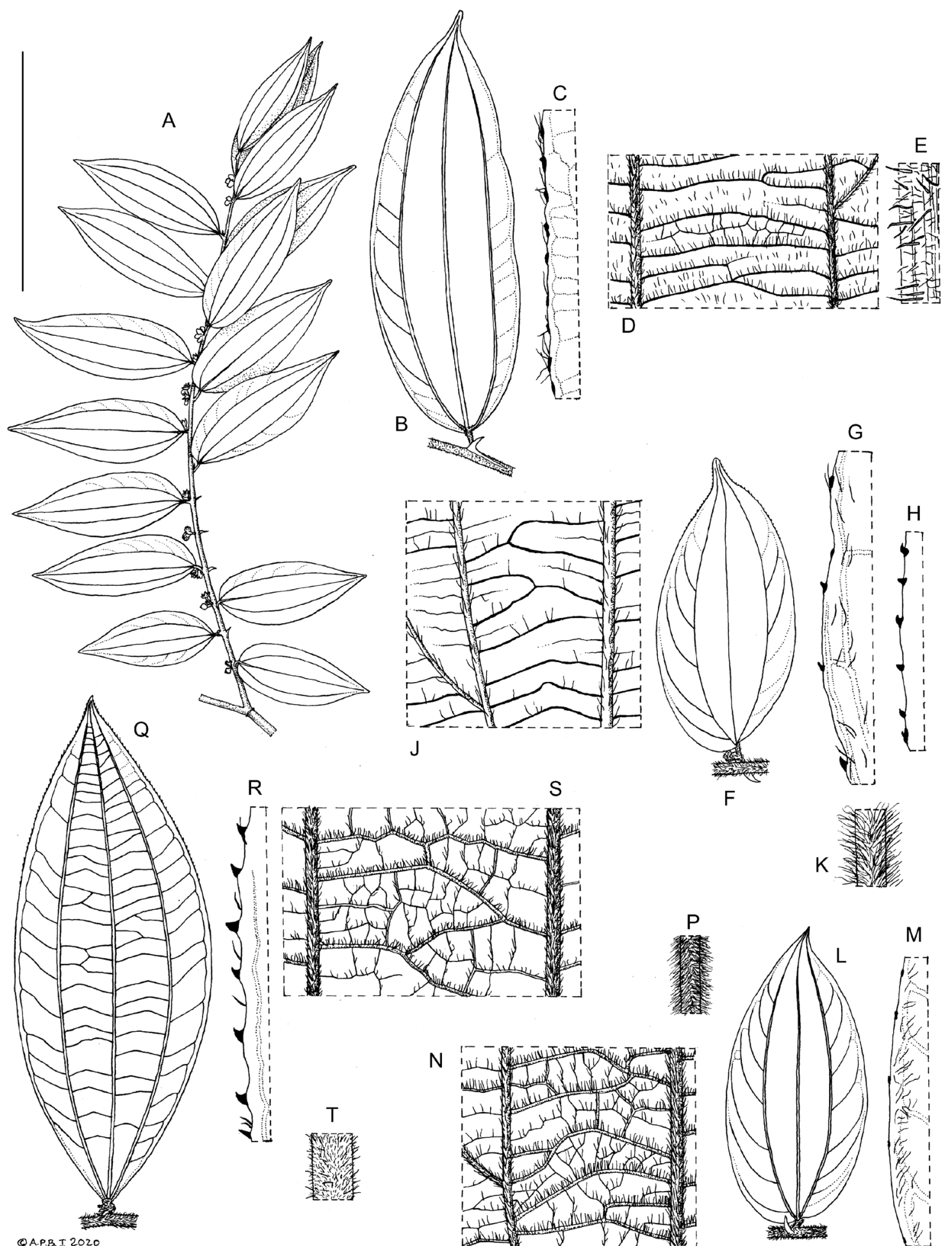

$\mathrm{F}$

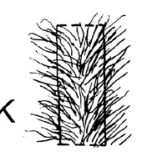

Fig. 1. Ziziphus borneensis. A - E Z. borneensis var. borneensis: A habit; B leaf, abaxial view; C leaf margin, adaxial view; D leaf lamina surface, abaxial view; E detail of branchlet indumentum; F - K Z. borneensis var. kinabalui: F leaf, adaxial view; G leaf margin, mid-margin, abaxial view; $\mathrm{H}$ leaf margin, distal margin, abaxial view; J leaf lamina surface, abaxial view; $\mathbf{K}$ detail of branchlet indumentum; L - P: Z. borneensis var. velutina: L leaf, abaxial view; M leaf margin, abaxial view; N leaf lamina surface, abaxial view; P detail of branchlet indumentum; Q - T Z. borneensis var. ranggam: Q leaf, abaxial view; $\mathbf{R}$ leaf margin, adaxial view; S leaf lamina surface, abaxial view; T detail of branchlet indumentum. Scale bar: $A=10 \mathrm{~cm} ; \mathrm{B}, \mathrm{F}, \mathrm{L}, \mathrm{Q}=5 \mathrm{~cm} ; \mathrm{C}, \mathrm{G}, \mathrm{H}, \mathrm{M}, \mathrm{R}=5$ mm; D, J, K, N, P, S, T = $1 \mathrm{~cm} ; \mathrm{E}=2.5 \mathrm{~mm}$. A, C from Forman \& Blewett 862; B, D, E from Elmer 20149; F - K from Clemens \& Clemens 30376; L - P from Tikau SAN 28913; Q - T from Church et al. 96. DRAWN BY ANDREW BROWN. 
2c. Ziziphus borneensis var. ranggam Cahen $\mathcal{E}$ Utteridge var. nov. Type: Indonesia, Borneo, West Kalimantan, Sintang, Bukit Baka National Park. Panjung butung, $250 \mathrm{~m} \mathrm{~N}$ of camp down Sungai Ella, along bank and near environs, $0^{\circ} 38^{\prime} \mathrm{S}$ $112^{\circ} 17^{\prime} \mathrm{E}, 315 \mathrm{~m}$, Church et al. 96 (holotype: K [K001420126], isotypes: E [E00781015], L [L.4197610]).

http:/ /www.ipni.org/urn:lsid:ipni.org:names:77218841-1

Branchlets densely hairy on young parts and distal portions, hairs variable, usually c. $0.5 \mathrm{~mm}$ long, spreading to appressed. Leaves narrow ovate (elliptic-oblong), (7.2 -) $10.6(-15.0) \times(3.0-) 4.3$ $(-5.3) \mathrm{cm}$; callosities protruding off a margin that is finely serrate in outline, serrations visible all along leaf margin but especially clearly near apex; strong marginal veins coming off the outside of the two outer main veins $>15$ on either side, intramarginal vein running along the leaf margin very distinct; venation reticulate abaxially, with the longitudinal venules between the transverse veins that join the main veins conspicuous and raised; lamina densely hairy abaxially on its entire surface. Fig. $1 Q-T$.

RECOGNITION. This variety is recognised in the longer leaves, to $15 \mathrm{~cm}$, with the margins distinctly finely serrate, the numerous strong marginal veins, $>15$, coming off the outside of the two outer main veins, and the longitudinal venules clearly visible between the transverse veins that join the main veins.

DISTRIBUTION. Borneo (Kalimantan, Sarawak), endemic. Map 3.

ADDITIONAL SPECIMENS EXAMINED. MALAYSIA. SARA-

WAK: KAPIT, Bukit Salong, Ulu Sampuran, Melinau, 900 m, 26 March 1980, Paie S.41581 (K, L); MIRI, Block No. 17, Bintulu Lumber Co. area, Suai, $450 \mathrm{ft}$ [150 m], 24 July 1977, Paie S.39200 (K, L).

HABITAT. Borneo rain forests; alt. $150-900 \mathrm{~m}$.

CONSERVATION STATUS. Vulnerable (VU). The variety is only known from three collections within an EOO of c. $18,000 \mathrm{~km}^{2}$ and Borneo rainforests are subjected to a decline in extent and quality. It thus meets the Blab(iii) criteria for VU. The type specimen was collected in Bukit Baka - Bukit Raya National Park (IUCN Category II).

PHENOLOGY. Collected in flower in Oct.; collected in fruit in March and July.

ETYMOLOGY. The varietal epithet is the local name indicated on the label of the type specimens (West Kalimantan, language unknown).

VERNACULAR NAMES. Ranggam (West Kalimantan, language not specified, fide Church et al. 96).
NOTES. The leaf venation in this variety is strikingly different from other Ziziphus borneensis varieties, with > 15 strong marginal veins on either side (Fig. 1R) and the reticulations of finer venules clearly visible (Fig. 1S). It is like $Z$. puberula in the marginal veins $>15$ (although sometimes $<15$ in Z. puberula) and the big, $>2 \mathrm{~cm}$, ellipsoid fruit, but differs in the dense indumentum of longer hairs on the branchlets and leaves (Fig. 1S \& $\mathrm{T}$ ), reticulation of leaf veinlets clearly visible, the presence of a distinct intramarginal vein running along the leaf margin (Fig. 1Q), subsessile fasciclelike cymes and subsessile fruit.

The variety is only known from three localities each at least $200 \mathrm{~km}$ apart from one another. Specimens of the Sarawak collections have a more reddish indumentum, but all share the same characteristic venation pattern.

2d. Ziziphus borneensis var. velutina Cahen $\mathcal{E}$ Utteridge var. nov. Type: Malaysia, Sabah, Ranau, Kundasang above Sosopodon, 11 April 1962, [the date on the label is 31 April 1962, which does not exist; 11 April was inferred from other collections above Sosopodon by Tikau in 1962] Tikau SAN 28913 (holotype: K [K001420127]; isotype: L [L.2336619]).

http://www.ipni.org/urn:lsid:ipni.org:names:77218842-1

Branchlets densely hairy on young parts and distal portions, hairs c. $1 \mathrm{~mm}$ long and mostly \pm spreading. Leaves narrow ovate, (4.6 -) 6.4 (- 7.5) $\times(1.9-) 2.8(-3.5) \mathrm{cm}$; callosities protruding off a margin that is finely serrate in outline, serrations

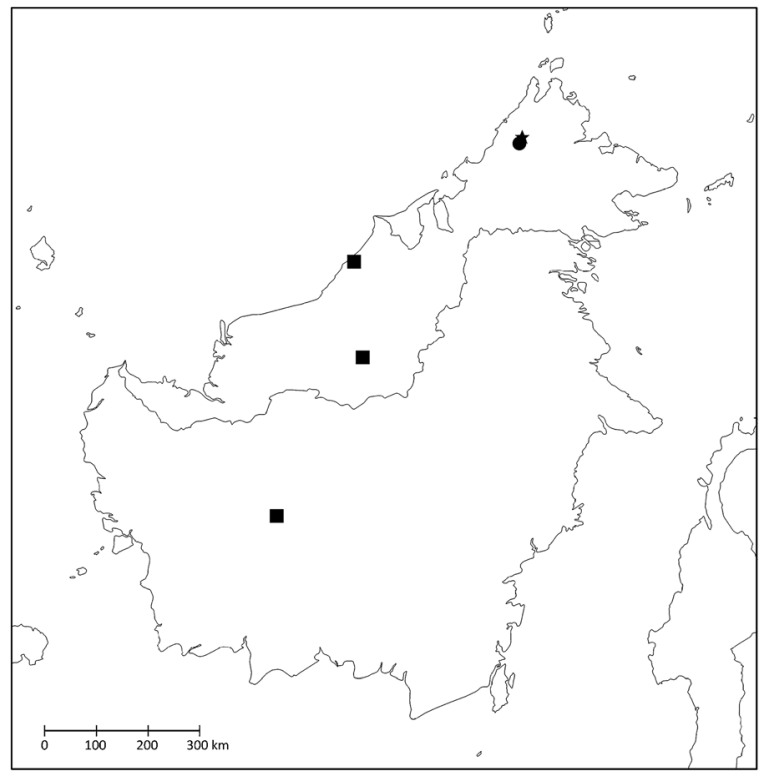

Map 3. Distribution of Ziziphus borneensis var. kinabalui (•), borneensis var. ranggam $(\mathbf{\bullet})$, borneensis var. velutina $(\star)$. 
clearly visible near leaf apex only; strong marginal veins coming off the outside of the two outer main veins c. 8 on either side, intramarginal vein running along the leaf margin indistinct; venation not clearly reticulate, transverse veins that join the main veins much stronger than the longitudinal venules between them; lamina densely hairy abaxially on its entire surface. Fig. 1L - P.

RECOGNITION. This variety is most like Ziziphus borneensis var. kinabalui in the densely hairy branchlets with c. $1 \mathrm{~mm}$ long hairs that are mostly \pm spreading and in the absence of a clearly visible intramarginal vein but differs in the abaxial lamina surface being entirely hairy (vs along major veins and transverse veins between the main veins only) and the leaf margin serrations clearly visible near the leaf apex only (vs clearly visible all along the leaf margin).

DISTRIBUTION. Borneo (Mount Kinabalu), Endemic. Map 3. ADDITIONAL SPECIMENS EXAMINED. MALAYSIA. SABAH: RANAU, Kinabalu near Kundasang, Sopodon, c. $4350 \mathrm{ft}$ [1300 m], 11 July 1963, Madani SAN 36786 (K, L).

HABITAT. Borneo montane rain forests; alt. c. $1300 \mathrm{~m}$. CONSERVATION STATUS. Data Deficient (DD). The variety is only known from the Kundasang-Sosopodon area near Mount Kinabalu. It thus meets the IUCN B1a criterion for Critically Endangered, but a decline or fluctuation of the population cannot be estimated or inferred. The specimens may have been collected within the Sosopodon Forest Reserve (IUCN Category Ia) where despite some fragmentation, forests seem well preserved overall in satellite images. The variety is considered here to be Data Deficient because the data is so uncertain that both LC and CR are plausible categories.

PHENOLOGY. Collected in fruit in April and July. ETYMOLOGY. The varietal epithet derives from the Italian velluto, velvet, itself derived from the Latin villus, hair, and refers to the dense indumentum of hairs on the abaxial surface of leaves making them soft to touch.

VERNACULAR NAMES. Kangom sapuon (Ranau fide Tikau SAN 28913).

NOTES. This variety differs from the other Ziziphus borneensis varieties in the combination of branchlets having dense, long, reddish, mostly spreading hairs, c. $1 \mathrm{~mm}$ long (Fig. 1P), strong marginal veins coming off outer main veins c. 8 on either side (Fig. 1L) and the abaxial lamina surface being completely covered in hairs (Fig. 1N).

3. Ziziphus calophylla Wall. (Wallich in Roxburgh 1824: 366). Berchemia calophylla (Wall.) G.Don (1832: 28). Type: Malaysia, Penang, Porter EICH 4230 (lectotype, selected here: K-W [K001038440]; isolectotypes: K-W [K001038441], K [2 barcodes on same sheet: K000723029, K000723030], M [M-0211794]).
Ziziphus ornata Miq. (Miquel 1856: 642) synon. nov. Type: Indonesia, Bangka Island, 1802 - 1818, Horsfield s.n. (lectotype, selected here: K [K001420128]).

Ziziphus horsfieldii sensu Beaman \& Anderson (2004: 276), pro parte, non Miq.

Woody climber to at least $25 \mathrm{~m}$ long; girth to at least $20 \mathrm{~cm}$ in diam., spiny. Branchlets terete, with conspicuous longitudinal striations, lenticels raised, densely hairy on young parts and distal portions, becoming sparsely hairy to glabrous when mature, hairs $<0.1 \mathrm{~mm}$ long, reddish. Stipules paired, one becoming a recurved spine, c. $4 \mathrm{~mm}$ long, the other one fugaceous, persistent on some flowering branchlets, entire, wide ovate, c. $3 \times 2 \mathrm{~mm}$, hairs dense, spines on distal branchlets often closely spaced, by c. $1 \mathrm{~cm}$. Leaves weakly discolorous, drying greenish-brown, blade \pm symmetric, (narrow ovate - ) elliptic (- narrow elliptic), (5.3 -) 11 (- 15) × (1.9 -) $4.5(-6) \mathrm{cm}$, subcoriaceous, apex attenuate to acuminate, base wide cuneate to rounded, usually symmetric, margins subentire to finely denticulate, $>100$ serrations on either side, each serration topped by a protruding callosity that dries darker than the lamina, c. $0.1 \mathrm{~mm}$ long; primary veins 3, impressed adaxially, raised abaxially, hairs sparse to dense along primary veins on either side of lamina, hairs c. $0.2 \mathrm{~mm}$ long; strong marginal veins coming off the outside of the two outer main veins usually absent (only 3 main veins conspicuous), sometimes visible, $>20$, faint intramarginal vein running along the leaf margin present; transverse veins between the main veins weak but discernible, coming off midrib at c. $90^{\circ}$, barely raised (not readily felt by touch), tightly spaced, usually $<1 \mathrm{~mm}$ from each other, \pm straight; higher order reticulations and areoles well-developed, visible with a hand lens; lamina subglabrous, with no to very few glands, mostly visible abaxially, drying darker than rest of lamina surface, slightly pitted, $\pm 0.1 \mathrm{~mm}$ in diam.; tufts of hairs rarely present in the axils at the base of the 3 main veins; petiole slightly dorsiventrally flattened, 5-11 mm long, hairs sparse to dense. Inflorescence of axillary pedunculate cymes, usually arranged in a panicle, c. 16 flowers in each cyme, cymes consisting of loose dichasia visibly branching $2-3$ times; peduncles dorsiventrally flattened $(0.2-) 1.2(-2.0) \mathrm{cm}$ long, hairs abundant to dense, appressed to spreading, c. $0.1 \mathrm{~mm}$ long; pedicels (1 -) $3(-5) \mathrm{mm}$ long, straight to curved; bracteoles entire, narrowly triangular, c. $2 \mathrm{~mm}$ long, hairs dense. Flower hypanthium densely hairy on the outer surface, c. $0.1 \mathrm{~mm}$ long, appressedantrorse, reddish; sepals triangular, c. $1.5 \mathrm{~mm}$ long, yellowish-green when fresh, glabrous and keeled adaxially; petals clawed, c. $1.4 \mathrm{~mm}$ long, obcordate; stamen filaments flat, subulate, c. $1.0 \mathrm{~mm}$ long, 


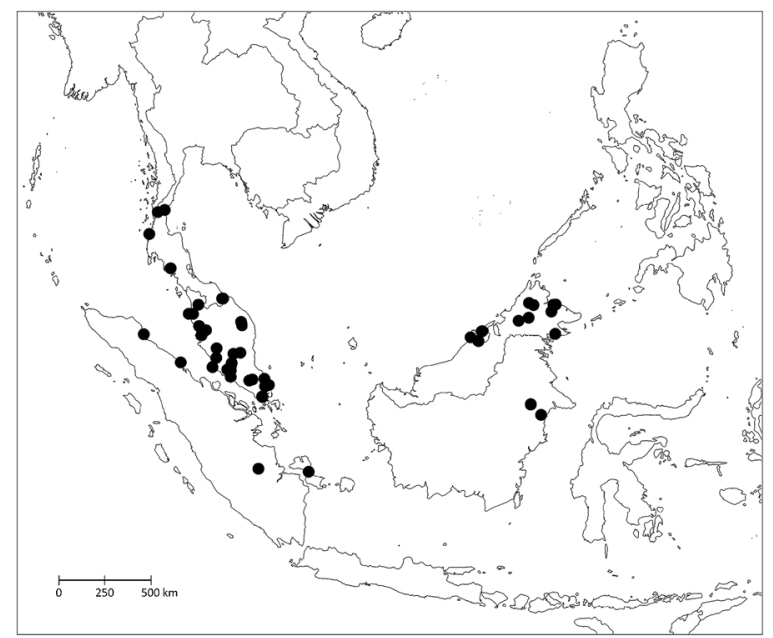

Map 4. Distribution of Ziziphus calophylla $(\bullet)$.

anthers c. $0.3 \mathrm{~mm}$ long, enclosed by petals; nectary disk pentagonal, 10-pitted, glabrous, slightly rugose; style arms 2, well-developed, c. $0.7 \mathrm{~mm}$ long, terminating in an expanded, almost flat stigmatic surface; ovary partially immersed, hairs dense. Fruit a drupe, ripening yellow-brown, $1.2-2.4 \times 0.9-1.7 \mathrm{~cm}$, (globose to ellipsoid) obovoid [wider towards apex], indumentum dense, hairs drying reddish, $<0.1 \mathrm{~mm}$ long; fruiting pedicels $3-5 \times 1 \mathrm{~mm}$; hypanthium remains sometimes saucer-shaped, usually caving in at base of fruit.

DISTRIBUTION. Brunei, Indonesia (Bangka, Kalimantan, Sumatra), Malaysia (Peninsular Malaysia, Sabah, Sarawak). Singapore, Thailand. Map 4.

ADDITIONAL SPECIMENS EXAMINED. BRUNEI. BELAIT: Bukit Sawat, Sungai Mau, 4.33N 114.29E

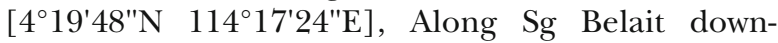
stream from village, $20 \mathrm{~m}, 15$ Oct. 1991, Simpson E Marsh 2006 (K, L); c. 0.5 mile above Bukit Puan, Sungei Belait, 31 Aug. 1960, Sinclair 10520 (E, L); INDONESIA. EAST KALIMANTAN: W. Koetai, no. 19, near L. Poehoes, c. 80 m, 15 Nov. 1995, Endert 4946 (K); East Kutai Reserve, vicinity of Sengata and Mentoko Rs, below 300 m, 8 Jan. 1978, Leighton 77 (L); MALAYSIA. SABAH: KENINGAU, Ulu Sg, Pingas pingas, 10 March 1988, Mantor SAN 122037 (K); KINABATANGAN, 0.5 mile $\mathrm{N}$ of Kinabatangan R. at Bukit Garam (1 mile E of Lamag), B.B.T.co. concession, $50 \mathrm{ft}$ [15 m], 19 June 1954, Wood A 4674 (L); NABAWAN, Syt. Benawood, logged area, Sg. Maadun, 22 June 1987, Jimpin SAN 118831 (K); RANAU, Tompurungan, 7 Aug. 1987, Amin E Francis SAN 119814 (K); Kampung liposu. Kampung Napung, 7 Dec. 1994, Sambuling 524 (K); SANDAKAN, Sibuga jeep track,
$200 \mathrm{ft}$ [60 m], 15 May 1961, Burgess SAN 25151 (K); Kabili-Sepilok F.R., Elopura, 300 ft [90 m], 20 April 1939, Enggoh 10522 (K, L); TAWAU, Mile 15 1/2 Quoin Hill Road, 12 May 1962, Gibot E Singh SAN 30014 (K, L); SARAWAK: 1865 - 68, Beccari 1631 (K); MIRI, Baram. Mata Kuching, S of Dulit Range, Ulu Tinjar, c. $1500 \mathrm{ft}$ [450 m], 11 Aug. 1974, Chai S.34788 (K, L); Marudi. Pulong Tau National Park (Western part). Ulu Sungai Baong, 339'56”N 115¹6'40"E, 9 May 2007, Julia et al. S.98021 (K); ibid., 971 m, 15 May 2007, Eryani et al. S.98444 (K); SRI AMAN, Lubok Antu Distr., $112^{\circ} 10^{\prime} \mathrm{N} 1^{\circ} 20^{\prime} \mathrm{E}, 15$ $\mathrm{m}$, R. Delok, secondary forest near Nanga Sumpa, 6 June 1993, Christensen 1446 (K).

HABITAT. Borneo lowland rain forests; alt. $0-1000 \mathrm{~m}$. CONSERVATION STATUS. Least Concern (LC). Ziziphus calophylla is widely distributed in much of western Malesia and does not appear to be threatened. In Borneo, it is likely that the taxon is declining and severely fragmented given the widespread destruction of rainforests. However, the species was collected in protected areas: Sepilok Virgin Jungle Reserve (IUCN Category not reported) in Sabah and Lambir Hills National Park (IUCN Category II) in Sarawak.

PHENOLOGY. Collected in flower in March - May and Oct.; collected in fruit in May, June, Aug., Nov. and Dec.

VERnACUlAR NAMES. Menaul Daun Besai (Iban, fide Christensen 1446); Surunit duru (Dusun, fide Sambuling 524).

USES. Fruit edible (fide Chai S.34788 and Christensen 1446). Fibres used to frame top part of baskets (fide Christensen 1446); medicinally used "against Rabus (white in the mouth) probably fungal attack" (fide Christensen 1446); sap drinkable (fide Christensen 1446). NOTES. Ziziphus calophylla is recognised by the leaves being long, usually $>10 \mathrm{~cm}$, leathery, usually elliptic, \pm symmetric, with only the three main veins conspicuous and a faint but distinct intramarginal vein running along the leaf margin. The species is morphologically similar to Z. suluensis, as noted by Merrill (1929), but differs in the abaxial leaf surface having no to few glands (vs many) and leaf shape usually elliptic and \pm symmetric (vs ellipticoblong and asymmetric). Other differences include leaves that are more coriaceous, on average longer $(\mathrm{c} .11 \mathrm{~cm}$ vs 8 $\mathrm{cm}$ ) with the leaf base wide-cuneate to rounded (vs frequently subcordate), inflorescences more branching and with more flowers (flowers c. 16 per cyme vs 8) and fruit often more ellipsoid-obovoid (vs globose-obovoid). Ziziphus calophylla and Z. havilandii could represent two ends of a spectrum in leaf size and leaf gland abundance with $Z$. suluensis covering some of the middle range.

In the protologue for Ziziphus calophylla, Wallich (in Roxburgh 1824) cites material "discovered on the hill of Pulo Pinang [Penang Island] by Mr. 
George Porter". Four sheets collected by Porter in Penang were located, and a K-W sheet is selected as lectotype here because it is in the East India Company Herbarium (EICH) and can be considered the 'top set' upon which Wallich worked, and the sheet selected [K001038440] has fruits, whereas the the second EICH specimen [K001038440] is sterile.

Ziziphus ornata Miq. is placed as a synonym here. As noted by King (1896), no apparent morphological character seems to separate it from Z. calophylla. In the protologue for Z. suluensis, Merrill (1926) noted the similarity between $Z$. suluensis and $Z$. ornata (=Z. calophylla), noting that "except in leaf size the characters of Ziziphus ornata Miq., ex descr., apply closely to the present species". In the protologue for Z. ornata Miquel (1856) cites material collected by Horsfield in Banka [Bangka]. A specimen identified as Z. ornata, possibly from Miquel's private herbarium, is available at U [U.1541152], but the collector is not specified and the collection locality (illegible) is not Bangka. However, a sheet labelled as collected in Bangka Island by Horsfield is available at $\mathrm{K}$ and designated as the lectotype here.

4. Ziziphus crebrivenosa C.B.Rob. (Robinson 1908: 201). Type: Philippines, Mindanao, Zamboanga, Sax River, 21 Feb. 1905, Williams 2335 (lectotype, selected here: NY [00415108]; isolectotypes: K [K001420129], NY [00415109], US [00094321]).

Ziziphus lenticellata Merr. (Merrill 1922: 532) synon. nov. Type: Malaysia, Sabah, Aug. 1920, Agama 1018 (lectotype, selected here: A [00051552]).

Woody climber to at least $15 \mathrm{~m}$ long; girth to at least $5 \mathrm{~cm}$ in diam., spiny. Branchlets terete, with longitudinal striations and many conspicuous, raised lenticels, densely hairy on young parts and distal portions, more sparsely hairy when mature, hairs c. $0.1 \mathrm{~mm}$ long, mostly appressed-antrorse, reddish, some whitish. Stipules modified into spines, forming clusters at the tip of developing shoots, single or 3 per node, 2 lateral and one below point of insertion of leaf or branchlet, often some deciduous and 1 or 2 remaining, spines recurved, c. $5 \mathrm{~mm}$ long, hairy. Leaves weakly discolorous, drying greenish-brown, paler abaxially, blade symmetric, elliptic (- wide elliptic), $6.5-17.5 \times$ $2.5-9.5 \mathrm{~cm}$, chartaceous, apex acute (- acuminate), base (obtuse -) cordate, usually symmetric, margins serrate, c. 70 serrations on either side, each serration topped by a minute protruding callosity that dries darker than the lamina, c. $0.1 \mathrm{~mm}$ long; primary veins 3, impressed adaxially, raised abaxially, hairs sparse to abundant along primary veins on both sides of lamina, hairs c. $0.2 \mathrm{~mm}$ long, straight to tortuous, mostly appressed, antrorse; strong marginal veins coming off the outside of the two outer main veins c. 25 on either side, \pm equally strong, ascending and usually forming loops near the margin but no clear intramarginal vein running along the leaf margin present, angle of divergence with outer main veins wide, c. $70^{\circ}$; transverse veins between the main veins conspicuous, coming off midrib at c. $90^{\circ}$, raised (readily felt by touch), spaced by c. $4 \mathrm{~mm}$ from each other, \pm straight, often branching; higher order reticulations discernible; lamina sparsely hairy abaxially (more densely along bigger veins), hairs c. $0.3 \mathrm{~mm}$ long, mostly appressed; domatia present in the axils at the base of the 3 main veins, pocket-like; petiole slightly dorsiventrally flattened, c. $4 \mathrm{~mm}$ long, hairs dense, indumentum extending to widened base of main veins adaxially. Inflorescence of axillary pedunculate cymes, < $1 / 2$ as long as subtending leaves, sometimes arranged in panicles when subtending leaves caducous, c. 12 flowers in each cyme, cymes loose dichasia visibly branching at least 3 times; peduncles $0-15 \mathrm{~mm}$ long, hairs dense; bracteoles entire to deeply bifid, narrowly triangular, c. $1 \mathrm{~mm}$ long, hairy. Flower hypanthium densely hairy abaxially; sepals triangular, c. $2 \mathrm{~mm}$ long, glabrous and keeled adaxially; petals clawed, c. $1.5 \mathrm{~mm}$ long, obcordate; stamen filaments flat, subulate, c. $1 \mathrm{~mm}$ long, anthers brownish, c. $0.4 \mathrm{~mm}$ long, enclosed by petals; nectary disk, pentagonal, 10-pitted, glabrous; style c. $1 \mathrm{~mm}$ long, flattened, arms 2, c. $0.1 \mathrm{~mm}$ long, glabrous; ovary partially immersed, hairs dense. Fruit a drupe, ripening reddish-brown, globose to ellipsoid, to $3 \mathrm{~cm}$ long, surface covered in raised, blister-like lenticels; fruiting pedicels to $1.5 \mathrm{~cm}$ long, $\mathrm{c}$.

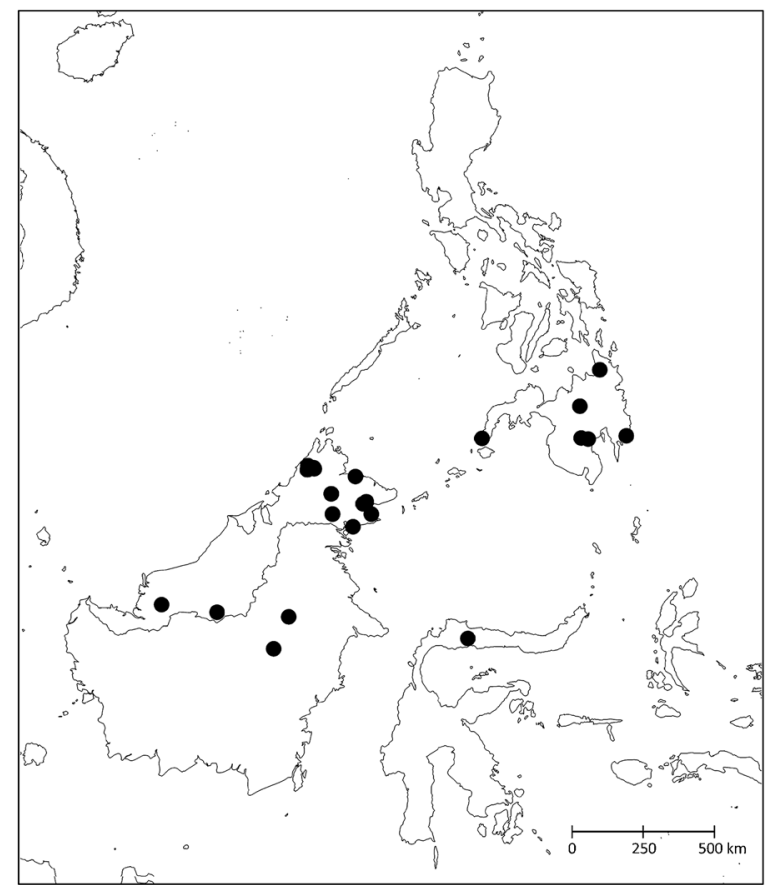

Map 5. Distribution of Ziziphus crebrivenosa (•). 
$2 \mathrm{~mm}$ wide, covered in lenticels, hypanthium remains at base of fruit usually indistinct.

DISTRIBUtION. Borneo (Kalimantan, Sabah, Sarawak), Mindanao and Sulawesi. Map 5.

ADDITIONAL SPECIMENS EXAMINED. INDONESIA. BORNEO: EAST KALIMANTAN, Berau, Mt Njapa on Kelai R., 100 m, 14 Oct. 1963, Kostermans 21286 (K, L); PT ACTR Camp Lebangan, km 42 from Batu Kenalung, 17 Jan. 1982, Kramadibrata 202 (K, L); MALAYSIA. SABAH: KотA BELUD, Dallas [6 $\left.6^{\circ} 02^{\prime} \mathrm{N} 116^{\circ} 28^{\prime} \mathrm{E}\right], 3000 \mathrm{ft}[900$ $\mathrm{m}$ ], 2 Dec. 1931, Clemens E Clemens 27375 (K); Delupid. Kampung Melangkap Tomis, $3 \mathrm{~km}$ dari Melangkap Tomis, 8 June 1996, Lugas 2310 (K); Nohutu, Kampung Melangkap Tomis, $4 \mathrm{~km}$ dari Melangkap Tomis, 11 July 1996, Lugas 2495 (K); LAHAD DATU, Silam [45ㅇ' $\left.118^{\circ} 13^{\prime} \mathrm{E}\right], \pm 200 \mathrm{ft}[50$ m], 21 Sept. 1963, Ambullah 36090 (K, L); Mile 3 on Kennedy Bay Timber Co.'s road, 15 miles ESE of Lahad Datu, 75 ft [20 m], 17 March 1955, Wood SAN 16070 (L); RANAU, Sungai Kolumpisahon. Kampung Nalumad, 5 batu dari kampung Nalumad, $10 \mathrm{~m}$ dari sungai Mokodou $\left[6^{\circ} 6^{\prime} \mathrm{N} 116^{\circ} 40^{\prime} \mathrm{E}\right], 13$ Sept. 1996, Andau 654 (K); Langanan Falls c. $3.6 \mathrm{~km} \mathrm{NW}$ of Poring Hot Springs, $6^{\circ} 4^{\prime} \mathrm{N}$ 116 41'E, 1200 m, 16 Aug. 1990, Beaman 10988 (K); SANDAKAN, s.l., Aug. 1918, Castillo 644 (K, P, US); SEMPORNA, Timbun Mata F.R., 15 Aug. 1938, Agama 9466 (K, L); TAWAU, Tawao [Tawau], Oct. 1922 - March 1923, Elmer 20880 (K, L, P, U); ibid., Elmer 21813 (L, U); Hap Seng logging area, Sri Usukan, $\pm 400 \mathrm{ft}[100 \mathrm{~m}], 13$ Sept. 1978, Madani $\mathcal{E}$ K Krispinus SAN 88461 (K, L); TONGOD, Lamag, Sungai Korong, Karamuak, $500 \mathrm{ft}$ [150 m], 5 Sept. 1973, Madani SAN 76313 (K); Ulu Sg Malung, Keramuak, 100 m, 15 June 1983, Sundaling SAN 97021 (K, L). SARAWAK: KAPIT, Naanga Sringin, Ulu Sungai Entuloh, Baleh, 18 Sept. 1989, Othman et al. S.57735 (K, L); SARIKEI, Ulu Mayeng, Kakus, c. 200 m, 14 July 1964, Luang S.21735 (K, L).

HABITAT. Borneo lowland and montane rain forests; alt. $0-1200 \mathrm{~m}$.

CONSERVATION STATUS. Near Threatened (NT). It is likely that the taxon is declining and severely fragmented given the widespread destruction of rainforests in Borneo (Gaveau et al. 2014), Mindanao (Viloria et al. 2005) and Sulawesi (Cannon et al. 2007). However, the taxon is distributed with an EOO greater than $200,000 \mathrm{~km}^{2}$. Also, the species occurs in montane forests possibly less exposed to heavy exploitation. Some specimens were collected in the following protected areas: Kinabalu National Park and ASEAN Heritage Park (IUCN Category II) in Borneo, Mount
Apo Natural Park (IUCN Category II) and Cabadbaran Watershed Forest Reserve (IUCN Category VI) in Mindanao.

PHENOLOGY. Collected in flower Feb. - April; collected in fruit in March (Wood 16070) but mostly June - Oct. VERNACULAR NAMES. Akar Menaul (Iban, fide Luang 21735); Aurinip (Kedayan, fide Agama 9466); Batang berduri (not specified, fide Kramadibrata 202); Kuku alang (Banjar, fide Agama 9466); Kuku menayul (not specified, fide Othman et al. 57735).

USES. Fruits edible (fide Madani SAN 76313 and Othman et al. S.57735).

NOTES. Ziziphus crebrivenosa is recognised in being the only species with numerous blister-like raised lenticels on its long, to $3 \mathrm{~cm}$, often ellipsoid fruits. It is most like Z. kunstleri in having leaves at least $10 \mathrm{~cm}$ long with clearly raised transverse veins that join the main veins on the abaxial surface and in having mature fruits to at least $2 \mathrm{~cm}$ in length. However, finer vein reticulations are not clearly raised in $Z$. crebrivenosa and transverse veins tend to join the main veins without branching (vs reticulations raised and transverse veins tending to branch in Z. kunstleri). In addition, branchlets of $Z$. crebrivenosa have raised lenticels whereas those of $Z$. kunstleri are superficial and tend to be concealed on the younger parts by the dense reddish indumentum.

Williams 2335 is designated as the type in the protologue for Ziziphus crebrivenosa (Robinson 1908) and a sheet of this material from NY where Robinson worked from 1903 to 1908 is selected here as the lectotype.

Merrill (1922) highlighted the "ellipsoid, not globose, entirely glabrous, conspicuously lenticellate fruits" in his protologue of Ziziphus lenticellata but compared vegetative characters of this species to those of $Z$. horsfieldii. He did not consider Z. crebrivenosa in this publication despite listing it in his An Enumeration of Philippine Plants the following year (Merrill 1923). No morphological character seems to separate $Z$. lenticellata from Z. crebrivenosa and it is placed as a synonym here. Merrill (1922) mentions Castillo 644 and Agama 1018 in the protologue for Z. lenticellata and the sheet of Agama 1018 from A is selected as the lectotype because it is in flower unlike those of Castillo 644 and may have been examined by Merrill.

5. Ziziphus cumingiana Merr. var. cumingiana (Merrill 1906: 206). Type: Philippines, Luzon, Laguna, Calawang [Calauan], 1836 - 1840, Cuming 453 (lectotype, selected here: L [L0550597]; isolectotypes: L [L0550985, L0551582], MEL [MEL 2441734]). 
Ziziphus bulusanensis Elmer ex Merr. (Merrill 1923: 522), nom. inval. pro syn.

Ziziphus borneensis sensu Beaman \& Anderson (2004: 275), pro parte, non Merr.

Ziziphus havilandii sensu Beaman \& Anderson (2004: 276), pro parte, non Ridl.

Ziziphus horsfieldii sensu Beaman \& Anderson (2004: 276), pro parte, non Miq.

Woody climber, to at least $20 \mathrm{~m}$ long, girth not recorded, spiny. Branchlets terete, with longitudinal striations and visible lenticels, sparsely to densely hairy on young parts and distal portions, becoming sparsely hairy to glabrous when mature, hairs c. $0.2 \mathrm{~mm}$ long, mostly appressed-antrorse, reddish. Stipules modified into spines, single, recurved, c. $3 \mathrm{~mm}$ long on distal branchlets, often hairy. Leaves weakly discolorous, drying greenish-brown, paler abaxially, blade asymmetric, ovate to narrow ovate (- narrow elliptic), 3.0 $10.0 \times 1.8-4.0 \mathrm{~cm}$, thin-chartaceous, apex attenuate to acuminate, base (cuneate - ) rounded (- cordate), usually clearly oblique, margins crenate, crenations weak but distinct, spaced by c. $3 \mathrm{~mm}$ at middle of margin, c. 25 on either side, each serration topped by a tuft of hairs along with a protruding callosity that dries darker than the lamina, c. $0.1 \mathrm{~mm}$ long; primary veins 3, (lowest marginal veins are strong, making it sometimes appear like there are 4 or 5 primary veins), impressed adaxially, raised abaxially, hairs sparse to abundant along primary veins on either side of lamina, often more densely adaxially, hairs c. $0.2 \mathrm{~mm}$ long; strong marginal veins coming off the outside of the two outer main veins c. 5 on either side, ascending and gradually diminishing, not forming conspicuous loops near margin, no clear intramarginal vein running along the leaf margin present, angle of divergence with outer main veins c. $35^{\circ}$; transverse veins between the main veins distinct, coming off midrib at c. $90^{\circ}$, barely raised (not readily felt by touch), spaced by c. $1 \mathrm{~mm}$ from each other, \pm straight; higher order reticulations and areoles well-developed, clearly visible with a hand lens, drying dark red and contrasting strongly with the lamina colour; lamina sparsely hairy; domatia often present in the axils at the base of the 3 main veins and at the junction between the marginal veins and the outer main veins, pocketlike and often with tufts of hairs, swelling sometimes visible adaxially just above junction between 3 main veins, drying darker than rest of lamina; petiole slightly dorsiventrally flattened, c. $5 \mathrm{~mm}$ long, hairs dense, with glands and foliaceous appendages, especially along edges of channel and near junction with leaf blade. Inflorescence of axillary short-peduncled, almost fascicle-like cymes, usually shorter than the subtending leaf's petiole, c. 10 flowers in each cyme, cymes dichasia with usually only peduncle and first 2 branches distinguishable; peduncles dorsiventrally flattened c. $2 \mathrm{~mm}$ long, hairs abundant, c. $0.1 \mathrm{~mm}$ long; pedicels c. $2 \mathrm{~mm}$ long, straight to slightly curved, sparsely hairy; bracteoles entire to deeply bifid, narrowly triangular, c. $1 \mathrm{~mm}$ long, hairy. Flower hypanthium sparsely hairy abaxially, hairs $<0.1 \mathrm{~mm}$ long, appressed, reddish to white; sepals triangular, c. $1.2 \mathrm{~mm}$ long, pale green when fresh, glabrous and keeled adaxially; petals clawed, c. $1.2 \mathrm{~mm}$ long, obcordate; stamen filaments flat, subulate, c. $1.0 \mathrm{~mm}$ long, anthers c. $0.2 \mathrm{~mm}$ long, enclosed by petals; nectary disk pentagonal, 10-pitted, glabrous, no distinguishable annulus surrounding ovary; style c. $1 \mathrm{~mm}$ long, flattened, arms 2, rudimentary, free for $0.1 \mathrm{~mm}$; ovary partially immersed, glabrous. Fruit a drupe, ripening yellow then black, c. $7 \times 6 \mathrm{~mm}$, obovoid [wider towards apex], glabrous; fruiting pedicels c. $3 \mathrm{~mm}$ long; hypanthium remains annular at base of fruit.

DISTRIBUTION. Borneo (Kalimantan, Sabah) and the Philippines (Alabat, Leyte, Luzon, Mindanao, Mindoro, Palawan, Visayas). Map 6.

ADDITIONAL SPECIMENS EXAMINED. INDONESIA. BORNEO:

EAST KALIMANTAN, W Koetai, no.18, near L. Poehoes, c. 70 m, 8 Aug. 1925, Endert 2411 (K, L); East Kutai Reserve, vicinity of Sengata and Mentoko Rs, $0^{\circ} 30^{\prime} \mathrm{N}$ $117^{\circ} 20^{\prime} \mathrm{E}$, below 300 m, 1 Feb. 1979, Leighton 487 (L); pr. Fluv. Boengaloen [Sungai Bengalon], 24 Nov. 1912, Rutten 754 (U); WEST KALIMANTAN, Soengei Sambas, 1893 - 1894, Hallier 1112 (L); MALAYSIA. SABAH: KINABATANGAN, Gomatong Fr. [Gomantong F.R.], 30 Jan. 1988, Joseph et al. SAN 123657 (E, K); Supu F.R. [Hutan Simpan Supu], Elopura, 160 feet [50 m], 21 Oct. 1938, Puasa 10098 (K, L); RANAU,

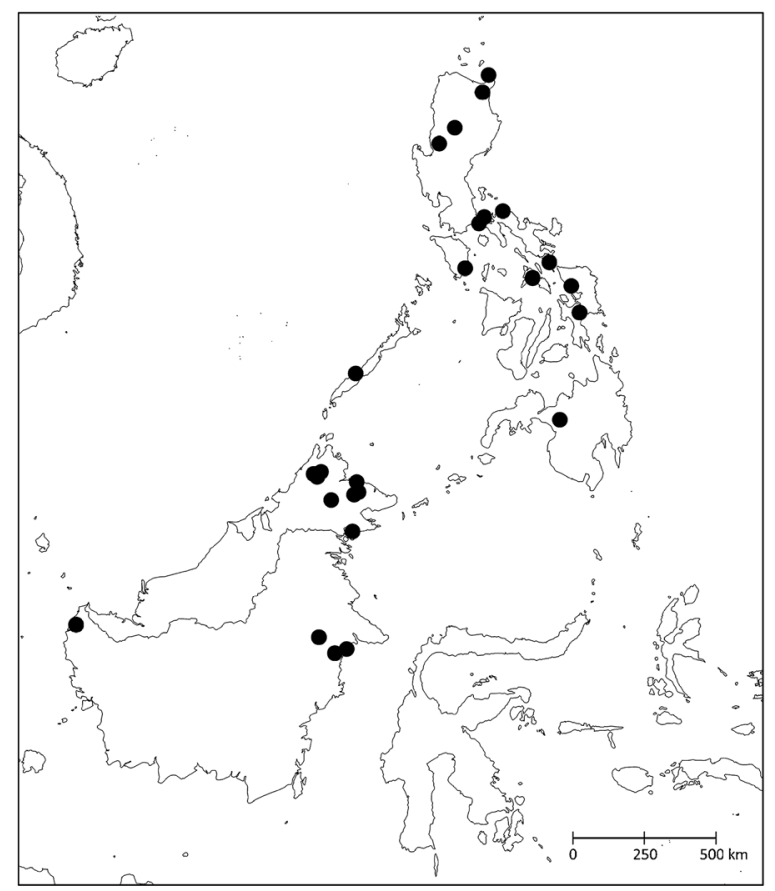

Map 6. Distribution of Ziziphus cumingiana var. cumingiana (•). 
Sungai Kepuakan, 18 June 1985, Amin et al. SAN 109777 (K, L); Narawang [6 $6^{\circ} 00^{\prime} 24^{\prime \prime N} 116^{\circ} 46^{\prime} 44^{\prime \prime E}$, 12 Aug. 1987, Amin $\mathcal{E}^{\circ}$ Francis SAN 119847 (K); Langsat $\quad\left[6^{\circ} 03^{\prime} 02^{\prime \prime} \mathrm{N} \quad 116^{\circ} 47^{\prime} 53^{\prime \prime E}\right], 8$ Sept. 1987, Amin et al. SAN 121074 (K); Kpg. Nalumad to Kpg. Pinawantai, 20 Oct. 1968, Ogata 11380 (L); Kampung Takutan. Tepi jalan raya ke SMK Timbua, 30 April 1995, Tadong 247 (K); SANDAKAN, Sibuga Road, Kebun China, 15 Sept. 1972, Kumin SAN 75600 (K, L); TAWAU, Tawao [Tawau], Oct. 1922 - March 1923, Elmer 21383 (K, U); TONGOD; Bintang Mas logging area Karamuak, 14 June 1975, Madani SAN 81174 (K, L).

HABITAT. Borneo lowland rain forests; alt. $0-300 \mathrm{~m}$. CONSERVATION STATUS. Least Concern (LC). The species has a wide distribution with collections in lowland forests across Borneo and in many islands of the Philippines (Alabat, Leyte, Luzon, Mindanao, Mindoro, Palawan, Visayas). In Borneo, it is likely that the taxon is declining and severely fragmented given the widespread destruction of rainforests. However, the species was collected in protected areas, e.g. Gomantong Protection Forest Reserve (IUCN Category Ia) in Sabah.

PHENOLOGY. Collected in flower in Nov. - Feb., April, June and Sept.; collected in fruit in April, June, Aug. - Oct.

VERNACULAR NAMES. Sandulangkani (Sungei Kinababatangan, fide Puasa 10098); Surinit (Dusun, fide Tadong 247).

USES. No recorded uses found.

NOTES. Ziziphus cumingiana var. cumingiana is recognised by the small glabrous fruits $(<0.9 \mathrm{~cm}$ in diam.) inserted in subsessile fascicle-like cymes. The only other species on Borneo known to have glabrous fruits are $Z$. cuspidata and $Z$. domatiata. The fruits of Z. cuspidata are bigger, on average $2.0 \times 1.5 \mathrm{~cm}$, and arranged in pedunculate cymes; those of $Z$. domatiata slightly bigger, c. $1.0 \times 0.8 \mathrm{~cm}$, also arranged in pedunculate cymes. The dark red venation when dry, including the smallest venules, is unique among Ziziphus species in Borneo, as is the sparse indumentum on the pedicels and flowers and the weakly and distantly crenate margin with a tooth and hairs inserted by the sinus of each crenation.

Ziziphus cumingiana var. cumingiana shares many morphological characters with Z. oenopolia (L.) Mill. which, despite being widely distributed from India to Australia (GBIF 2019), has apparently not yet been recorded in Borneo. Both species have leaves obliquely ovate, $<10 \mathrm{~cm}$ in length, with strong marginal veins, subsessile fascicle-like cymes and fruits small, c. $1 \mathrm{~cm}$ in diam., glabrous, globose to obovoid. Ziziphus oenopolia differs from Z. cumingiana var. cumingiana in the transverse veins between the main veins strong and ascending, and the leaves densely hairy abaxially. The widespread, cultivated and sometimes naturalised
Z. mauritiana and Z. jujuba also have subsessile fascicle-like cymes and globose fruits but the leaf apex is usually rounded or notched as opposed to attenuate. Lectotypes for both Z. mauritiana and Z. oenopolia were recently selected in a review of the nomenclature of the species of Ziziphus occurring in Australia (Kellermann 2020).

Ziziphus cumingiana var. pilosa Merr. (Merrill 1923: 522) differs from $Z$. cumingiana var. cumingiana in the more densely hairy leaf surface abaxially. The difference is marked and while specimens of this variety collected in the Philippines are available in herbaria, it is not known to have been found in Borneo. Vernacular names of $Z$. cumingiana in the Philippines are listed by Merrill (loc. cit.).

Merrill (1906) did not designate a type specimen in the protologue for Ziziphus cumingiana but lists Cuming 453 as illustrative and a sheet of this material, which is in flower, is selected here as the lectotype.

Ziziphus bulusanensis is listed as a synonym of Z. cumingiana by Merrill (1923) but because there is no retrievable diagnosis or description associated with it, the name seems to have not been validly published.

6. Ziziphus cuspidata Cahen $\mathcal{E}$ Utteridge sp. nov. Type: Malaysia, Sabah, Sandakan, Mile 75.5 Telupid Road, 15 Aug. 1979, Gibot SAN 91255 (holotype: K [K001420131]; isotypes: KEP-not seen, L [L.2328612], SAR-not seen).

http://www.ipni.org/urn:lsid:ipni.org:names:77218843-1

Ziziphus horsfieldii sensu Beaman \& Anderson (2004: 276), pro parte, non Miq.

Woody climber to at least $15 \mathrm{~m}$ long; girth to at least $6 \mathrm{~cm}$ in diam., spiny. Branchlets terete, with longitudinal striations and visible lenticels, densely hairy on young parts and distal portions, more sparsely hairy on mature parts, hairs mostly 0.5 $1 \mathrm{~mm}$ long, curved to tortuous, spreading to appressed-antrorse, reddish, some whitish. Stipules modified into spines, forming clusters at the tip of developing shoots, usually single at maturity, occasionally 3-whorled at branching nodes, spines recurved, c. $3 \mathrm{~mm}$ long, hairy when developing, glabrous at maturity. Leaves weakly discolorous, drying yellowish-green to brown adaxially, paler abaxially, blade variable in size and shape between individuals, usually asymmetric, (narrow oblong -) elliptic (- ovate), $2.5-8.0 \times 1.0-4.5 \mathrm{~cm}$, subcoriaceous, apex (acute - ) attenuate (- acuminate), base (obtuse -) rounded (- subcordate), usually symmetric, only rarely clearly oblique, margins weakly serrate, c. 50 serrations on either side, each serration topped by a minute protruding 
callosity that dries darker than the lamina, c. $0.1 \mathrm{~mm}$ long, margin slightly thickened, glabrous; primary veins 3, impressed adaxially, raised abaxially, hairs abundant along primary veins on both sides of lamina, hairs c. $0.5 \mathrm{~mm}$ long, straight to tortuous, mostly appressed, antrorse; marginal veins coming off the outside of the two outer main veins $3-15$, usually c. 6 , strong, ascending and forming loops near the margin but no clear intramarginal vein running along the leaf margin, angle of divergence with outer main veins $20-40^{\circ}$; transverse veins between the main veins conspicuous, coming off midrib at c. $90^{\circ}$, barely raised (not readily felt by touch), spaced by $1-2 \mathrm{~mm}$ from each other, more often slightly zigzagging than straight, often branching; higher order reticulations discernible; lamina abundantly hairy abaxially to more rarely subglabrous, hairs c. $0.5 \mathrm{~mm}$ long, reddish, mostly spreading; domatia present in the axils at the base of the 3 main veins, pocket-like; petiole slightly dorsiventrally flattened, $3-7 \mathrm{~mm}$ long, hairs dense, indumentum extending to widened base of main veins adaxially. Inflorescence of axillary pedunculate cymes, $<1 / 2$ as long as subtending leaves, c. 8 flowers in each cyme, cymes loose dichasia with usually 2 terminal elongate branches visible; peduncles c. $6 \mathrm{~mm}$ long with dense indumentum of hairs shorter and more whitish than on branchlets, hairs mostly spreading, $<0.1 \mathrm{~mm}$ long; pedicels to $3 \mathrm{~mm}$ long, hairs dense, straight to sometimes curved; bracteoles variously laciniate, often deeply bifid, c. $1 \mathrm{~mm}$ long, hairy, especially on margins, subglabrous abaxially. Flower fragrant (fide Jacobs 5328); hypanthium densely hairy abaxially, hairs paler and much shorter than on branchlets, $<0.1 \mathrm{~mm}$ long, appressed-antrorse to spreading; sepals triangular, c. $2 \mathrm{~mm}$ long, yellowish-green when fresh, glabrous and keeled adaxially; petals clawed, c. $1.5 \mathrm{~mm}$ long, obcordate, whitish; stamen filaments flat, subulate, c. $1 \mathrm{~mm}$ long, anthers brownish, c. $0.5 \mathrm{~mm}$ long, enclosed by petals; nectary disk orange, pentagonal, 10pitted, glabrous; style arms 2, free to at least $1.2 \mathrm{~mm}$ long, glabrous; ovary partially immersed, glabrous. Fruit a drupe, ripening yellow-orange, globose to ellipsoid, $(1.5-) 2.0(-2.2) \times(1-) 1.5$ $(-1.8) \mathrm{cm}$, usually with a rigid point at the apex, $\mathrm{c}$. $1 \mathrm{~mm}$ long, surface smooth, glabrous; fruiting pedicels c. $5 \times 2 \mathrm{~mm}$, hypanthium remains at base of fruit saucer-shaped, c. $5 \mathrm{~mm}$ in diam. Fig. 2.

RECOGNITION. Most like Ziziphus horsfieldii and Z. domatiata in having pedunculate cymes, fruits < $1.5 \times$ longer than wide, leaves usually $<7 \times 3 \mathrm{~cm}$ with strong marginal veins coming off the outer main veins usually $<8$ on either side. It differs

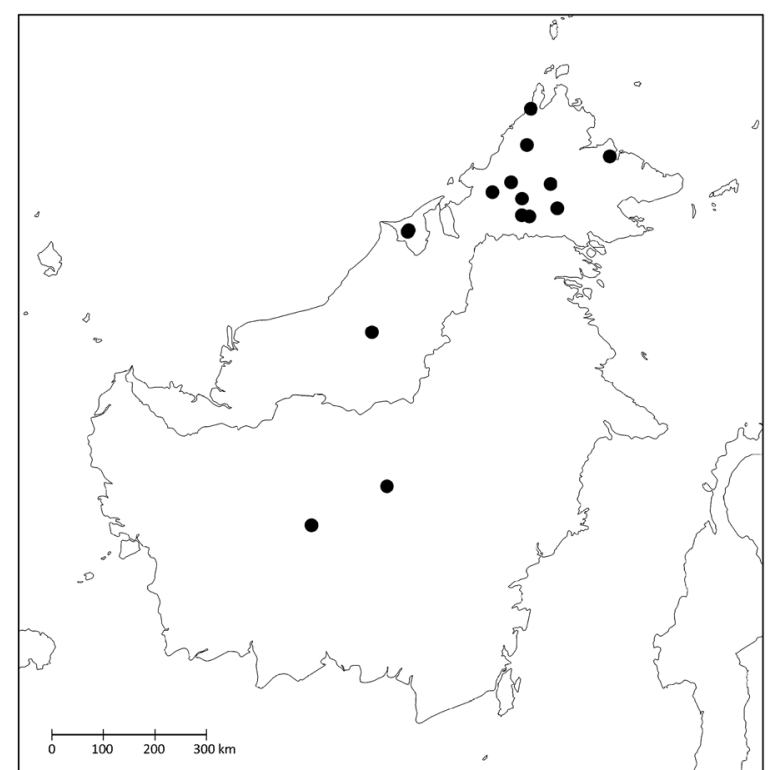

Map 7. Distribution of Ziziphus cuspidata $(\bullet)$.

from both species in having bigger fruits, c. $2 \times$ $1.5 \mathrm{~cm}$ (vs c. $1.1 \times 1.1 \mathrm{~cm}$ in $Z$. horsfieldii and c. 1.0 $\times 0.8 \mathrm{~cm}$ in $Z$. domatiata) and the leaf lamina usually being hairy abaxially (vs subglabrous). It also differs from $Z$. horsfieldii in having glabrous, globose to ellipsoid fruits (vs densely hairy, obovoid), shorter petioles, $3-7 \mathrm{~mm}$ (vs usually c. 10 $\mathrm{mm}$ ) and a more often symmetric lamina base, and from $Z$. domatiata in having fruits with the style remains forming a rigid point (vs muticous) and leaves with c. 6 strong marginal veins on either side (vs c. 4).

DISTRIBUTION. Borneo (Brunei, Kalimantan, Sabah, Sarawak), possibly endemic. Map 7.

ADDITIONAL SPECIMENS EXAMINED. BRUNEI. BELAIT: Kg. Tenajor, Labi, 2 Nov. 1994, Nangkat et al. BRUN 15775 (K); Labi Forest Reserve, compartment 13, $4^{\circ} 27^{\prime} \mathrm{N}$ $114^{\circ} 29^{\prime} \mathrm{E}, 60 \mathrm{~m}$, Osman et al. BRUN 16491 (K); INDONESIA. BORNEO: CENTRAL KALIMANTAN, Kalteng, Samba, Sungai Samba, 042'56.6"S 11246'46.5"E, 350 m, 19 Feb. 1995, Jarvie E R Ruskandi 6235 (K, L); P.T. Pamenang logging concession $\mathrm{Rd} \mathrm{c.} \mathrm{km} 20,0^{\circ} 2 \mathrm{~S}$ $114^{\circ} 6$ 'E, 23 June 1990, Ridsdale PBU 628 (E, K, L); MALAYSIA. SABAH: BELURAN, Ulu Tongod, 2 Aug. 1983, Han et al. SAN 99846 (K, L); KENINGAU, Sungai Siliawan, Sepulut F.Res., 22 March 1986, Krispinus $\mathcal{E}^{\circ}$ Sumbing SAN 113903 (K, L); Ulu Sg. Sambuaa, 27 Sept. 1988, Krispinus SAN 125205 (K, L); KOTA BELUD, Mt Templer F. Reserve, 1500 ft [450 m], 10 Feb. 1966, Kanis Eे Kuripin SAN 54380 (K, L); NABAWAN, Labang, Sepulut fr, 22 Oct. 1988, Krispinus SAN 125255 (K); Syrikat Undan Sd. Bh. Logging Area KM18 Jalan Nabawan/Pandewan, 27 March 1990, 


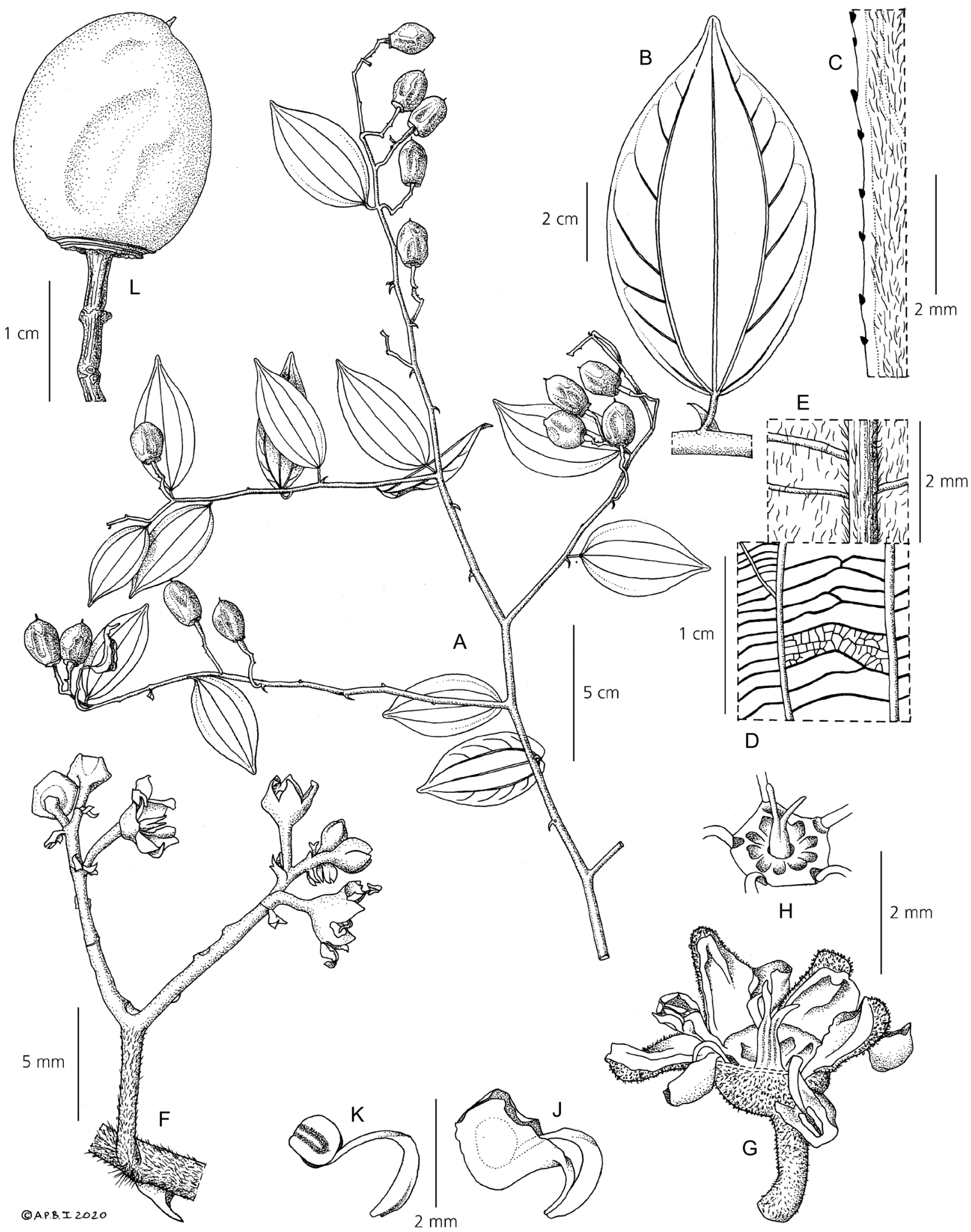

Fig. 2. Ziziphus cuspidata. A habit; B leaf, abaxial view; C leaf margin, abaxial view; D leaf lamina surface (indumentum omitted), abaxial view; E detail of leaf lamina surface, abaxial view; $\mathbf{F}$ inflorescence; G flower with a sepal removed (rehydrated); $\mathbf{H}$ flower centre (dry), viewed from above; J petal and stamen, side view; K stamen; L fruit. A - E from Gibot 91255; F - K from Sumbing SAN 128564; L from Osman et al. BRUN 16491. DRAWN BY ANDREW BROWN. 
Sumbing SAN 128564 (E, K, L); RANAU, Kampung Bundu Tuhan, Buntui, Kg. Himbaan, $5^{\circ} 56^{\prime} 58^{\prime \prime} \mathrm{N}$ 116 32'46"E, 28 Dec. 1993, Soibeh 642 (K); SANDAKAN, Mile 75.5 Telupid Road, 15 Aug. 1979, Gibot SAN 91255 (K, L); TENOM, 15 Aug. 1992, Meijer SAN 136518 (K, US); TONGOD, Block 8, Sabah Foundation Unlogged area, Seranum, 13 Sept. 1983, Embun SAN 101239 (K, L); SARAWAK: KAPIT, left bank of Rajang R., c. $10 \mathrm{~km}$ below Belaga, Segaham range, near Belaga airfield, approx. $2^{\circ} 40^{\prime} \mathrm{N} 113^{\circ} 50^{\prime} \mathrm{E}$, below $500 \mathrm{~m}, 27$ Aug. 1958, Jacobs 5328 (K, L).

HABITAT. Borneo lowland rain forest; alt. 60 - $450 \mathrm{~m}$. CONSERVATION STATUS. Near Threatened (NT). It is likely that the taxon is declining and severely fragmented given the widespread destruction of rainforests in Borneo. However, the taxon is distributed with an EOO greater than $150,000 \mathrm{~km}^{2}$ and some specimens were collected in or close to protected areas, e.g. Bukit Baka - Bukit Raya National Park (IUCN Category II) in Kalimantan, Maliau Basin Protection Forest Reserve (IUCN Category Ia) and Tenompok Protection Forest Reserve (IUCN Category Ia) in Sabah.

PHENOLOGY. Collected in flower in March and Aug. Sept.; collected in fruit in Feb., March, May, June and Aug. - Oct.

ETYMOLOGY. The specific epithet is derived from the Latin cuspidatus, pointy, and refers to the style remains forming a distinctive, conspicuous, rigid point at the apex of the fruit.

VERNACULAR NAMES. Kuku menaul (Iban, fide Osman et al. BRUN 16491); Mata kuling puru (Dusun, fide Soibeh 642).

USES. No recorded uses found.

NOTES. Ziziphus cuspidata had mostly been identified as Z. sp. and Z. horsfieldii in herbaria. It superficially resembles $Z$. horsfiedii but is easily distinguished in the fruits being glabrous (vs densely hairy) (Fig. 2L) and leaves being hairy with a petiole $3-7 \mathrm{~mm}$ long (vs subglabrous leaves and petiole c. $1 \mathrm{~cm}$ long) (Fig. 2B). The species characteristically dries yellowish. A point formed by the style remains at the apex of the fruits is visible in all Ziziphus species in Borneo except perhaps $Z$. domatiata, but is particularly conspicuous and rigid in this species (Fig. 2A \& L).

7. Ziziphus domatiata Cahen Eं Utteridge sp. nov. Type: Indonesia, East Kalimantan, Wanariset research area, Rintis Baru, Km 2, $1^{\circ} \mathrm{S} 117^{\circ} \mathrm{E}, 50 \mathrm{~m}$, 3 April 1991, Ambriansyah $\mathcal{E} \odot$ Arifin W702 (holotype: K [K001420132]; isotype: L [L.2332322]).

http:/ /www.ipni.org/urn:lsid:ipni.org:names:77218844-1

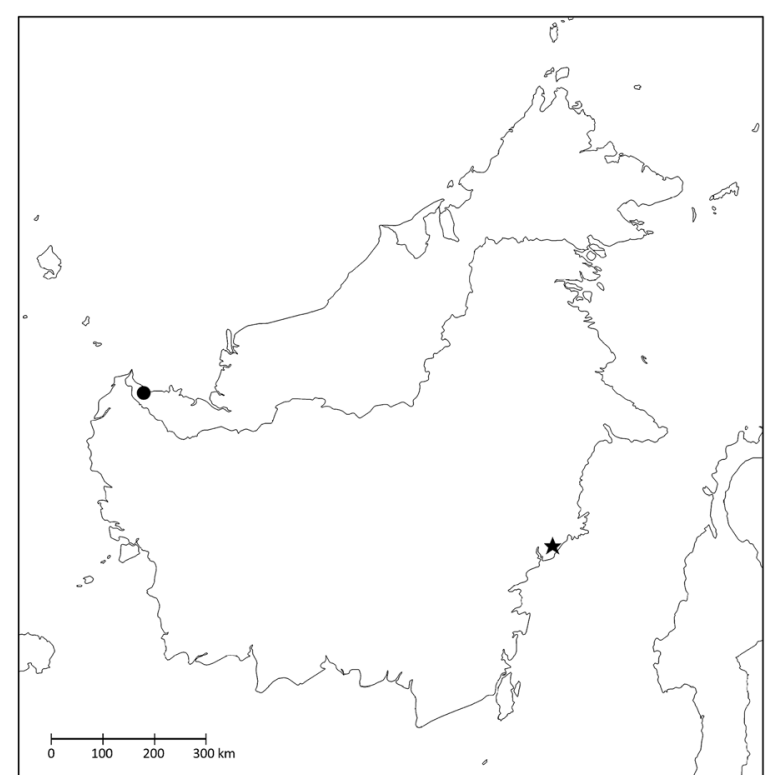

Map 8. Distribution of Ziziphus domatiata ( $\star$ ) and Z. ridleyana $(\bullet)$.

Woody climber, girth to at least $3 \mathrm{~cm}$ in diam., spiny. Branchlets terete, with longitudinal striations and conspicuous, raised lenticels, hairs sparse, c. $0.5 \mathrm{~mm}$ long mixed with shorter hairs $<0.1 \mathrm{~mm}$ long, spreading to appressed-antrorse. Stipules modified into spines, single, slightly recurved, c. $2 \mathrm{~mm}$ long, subglabrous. Leaves weakly discolorous, drying greenish-brown, blade asymmetric, narrow ovate (ovate), $3.5-5.5 \times 1.7-3.1 \mathrm{~cm}$, chartaceous to subcoriaceous, apex attenuate to acuminate, base cuneate to subcordate, usually clearly oblique, margins weakly crenate-serrate, c. 60 serrations on either side, each serration topped by a protruding callosity that dries darker than the lamina, c. $0.1 \mathrm{~mm}$ long; primary veins 3 , impressed adaxially, raised abaxially, hairs sparse to dense along primary veins on either side of lamina, hairs c. $0.3 \mathrm{~mm}$ long; strong marginal veins coming off the outside of the two outer main veins $(2-) 4(-8)$ on either side, ascending and gradually diminishing, rarely forming conspicuous loops near margin, no clear intramarginal vein running along the leaf margin present, angle of divergence with outer main veins c. $45^{\circ}$; transverse veins between the main veins weak but discernible, coming off midrib at c. $90^{\circ}$, barely raised (not readily felt by touch), spaced by c. $1 \mathrm{~mm}$ from each other, more often slightly zigzagging than straight; higher order reticulations barely discernible; lamina subglabrous; domatia present at the junction between the marginal veins and the outer main veins, pocket-like and with tufts 
of hairs; petiole slightly dorsiventrally flattened, c. $5 \mathrm{~mm}$ long, hairs dense, indumentum extending to widened base of main veins adaxially. Inflorescence of axillary pedunculate cymes, cymes loose dichasia (inferred from fruiting material) with usually peduncle and first 2 branches clearly elongate and next branches short and less distinct; peduncles c. $5 \mathrm{~mm}$ long; bracteoles not seen. Flower unknown. Fruit a drupe, ripening creamy-grey, c. $1.0 \times 0.8 \mathrm{~cm}$, subglobose to obovoid, glabrous, smooth; fruiting pedicels c. $3 \mathrm{~mm} \times 1 \mathrm{~mm}$; hypanthium remains saucer-shaped at base of fruit. Fig. 3 .

RECOGNITION. Most like Ziziphus horsfieldii in having pedunculate cymes, narrow ovate leaves, which are subglabrous abaxially except along larger veins and with tufts of hairs at the junction between the marginal and outer main veins. It differs in the glabrous, subglobose fruit, ripening creamy-grey, c. $1.0 \times 0.8 \mathrm{~cm}$ (vs fruit densely covered in reddish hairs, obovoid, ripening yellowish-green, c. $1.1 \times 1.1$ $\mathrm{cm})$. Vegetatively, it differs in the smaller leaves, 3.5 $-5.5 \times 1.7-3.1 \mathrm{~cm}$ (vs $3.5-10.0 \times 1.2-4.5 \mathrm{~cm})$, weakly crenate-serrate margin with c. 60 serrations on either side (vs finely denticulate and c. 100 serrations on either side) and fewer strong marginal veins, c. 4 on either side but often less (vs c. 6 and rarely $<5$ ).

DISTRIBUTION. Borneo (East Kalimantan). Endemic. Map 8.

HABITAT. Borneo lowland forests; alt. c. $50 \mathrm{~m}$. CONSERVATION STATUS. Critically Endangered (CR). Ziziphus domatiata is known from a single collection in the Wanariset Tropical Forest Research Station area, about $38 \mathrm{~km}$ north of Balikpapan, East Kalimantan. It was collected in 1991 in a Mixed Dipterocarp Forest, a habitat that has been subject to extensive logging in East Kalimantan (Kartawinata 2008). Because it is known from a single location and its potential EOO is inferred to be declining, it meets the Blab(iii) criteria for CR. PHENOLOGY. Collected in fruit in April.

ETYMOLOGY. Named for the presence of domatia in the axils at the junction between the marginal veins and the outer main veins, pocket-like and with tufts of hairs.

USES. Fruits edible (fide Ambriansyah E Arifin W702). NOTES. This species is only known from a single collection. Vegetatively it closely resembles Ziziphus horsfieldii in the leaves being subglabrous abaxially with tufts of hairs at the junction between the marginal veins and the outer main veins (Fig. 3D). The only other known Ziziphus species of Borneo with glabrous fruits are $Z$. cuspidata and

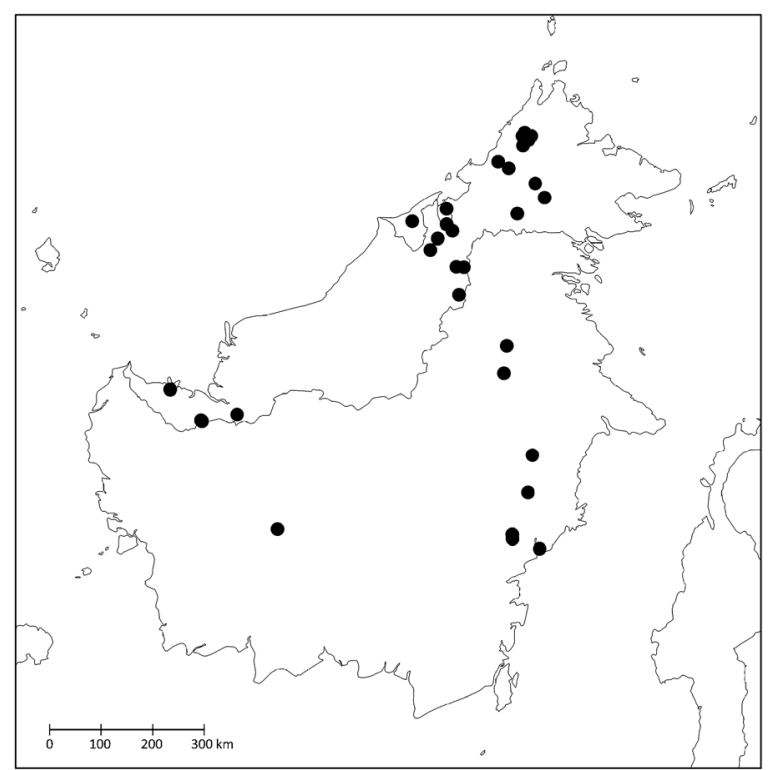

Map 9. Distribution of Ziziphus havilandii (•).

Z. cumingiana. It differs from Z cuspidata in having abaxially glabrous leaves except along the main and marginal veins (vs usually hairy) (Fig. 3D) with c. 4 or less strong marginal veins on either side (vs c. 6) (Fig. 3A \& B), in the tufts of hairs at the junction between the marginal veins and the outer main veins (vs sometimes in the axils at the base of the 3 main veins only) (Fig. 3D), and the fruits c. $1.0 \times 0.8 \mathrm{~cm}$ and muticous (vs c. $2 \times$ $1.5 \mathrm{~cm}$ and style remains forming a rigid point) (Fig. 3E). Z. cumingiana has smaller fruits (c. $7 \times$ $6 \mathrm{~mm} \mathrm{~cm}$ in diam.) inserted in subsessile fasciclelike cymes (vs pedunculate cymes) and leaves thinchartaceous (vs chartaceous to subcoriaceous), with a visibly reticulate venation drying darker than lamina surface (vs reticulation indistinct and veins drying paler than lamina surface).

8. Ziziphus havilandii Ridl. (Ridley 1931: 495). Type: Malaysia, Sarawak, Kuching, Feb. 1893, Haviland 2134 (lectotype, selected here: K [K000723019]).

Ziziphus borneensis sensu Beaman \& Anderson (2004: 275), pro parte, non Merr.

Woody climber to at least $30 \mathrm{~m}$ long; girth to at least $20 \mathrm{~cm}$ in diam., spiny. Branchlets terete, with longitudinal striations and visible lenticels, densely hairy on young parts and distal portions, becoming sparsely hairy to 


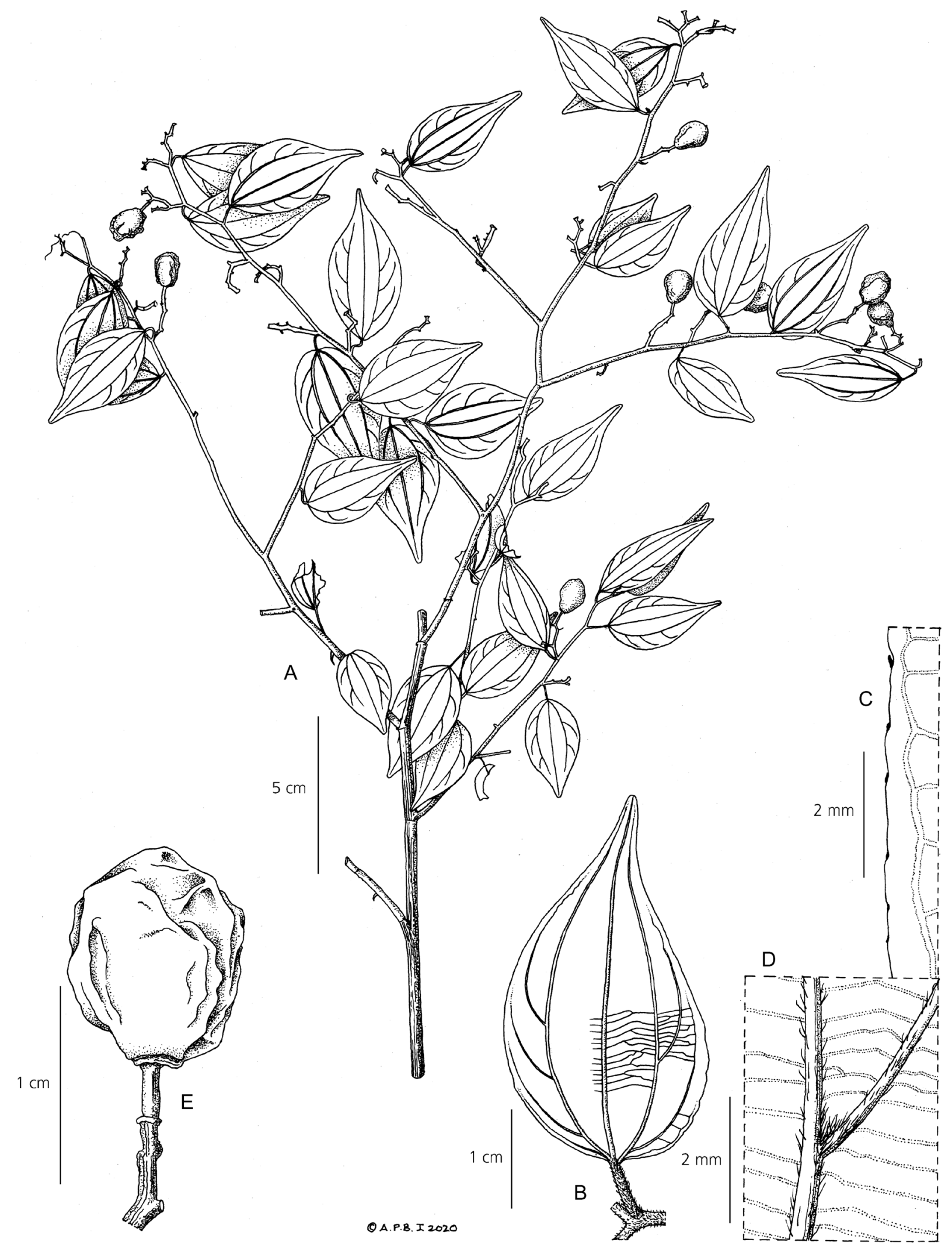

Fig. 3. Ziziphus domatiata. A habit; B leaf showing part of scalariform venation (indumentum shown only on petiole and branchlet), abaxial view; C leaf margin, abaxial view; D detail of domatium at junction between outer main vein and marginal vein, abaxial view; E fruit. A - E from Ambriansyah \& Arifin W702. DRAWN BY ANDREW BROWN. 
glabrous when mature, hairs straight to curved, spreading to appressed-antrorse. Stipules paired, one becoming a recurved spine, c. $3 \mathrm{~mm}$ long, the other one fugaceous, persistent on some flowering branchlets, entire, wide ovate, c. $3 \times 2 \mathrm{~mm}$, hairs dense, spines on distal branchlets often closely spaced, by c. $1 \mathrm{~cm}$. Leaves weakly discolorous, drying greenish-brown, blade asymmetric, narrow ovate to elliptic-oblong, $(1.0-) 2.5-5.5$ $(-6.5) \times(0.5-) 1.2-2.5(-3.5) \mathrm{cm}$, chartaceous, apex attenuate to acuminate, base rounded, usually symmetric, margins subentire to finely denticulate, c. 75 serrations on either side, each serration topped by a protruding callosity that dries darker than the lamina, c. $0.1 \mathrm{~mm}$ long; primary veins 3 , impressed adaxially, raised abaxially, hairs sparse to dense along primary veins on either side of lamina, hairs c. $0.2 \mathrm{~mm}$ long; strong marginal veins coming off the outside of the two outer main absent (only 3 main veins conspicuous), faint intramarginal vein running along the leaf margin present; transverse veins between the main veins weak but discernible, coming off midrib at c. $90^{\circ}$, barely raised (not readily felt by touch), tightly spaced, usually $<1 \mathrm{~mm}$ from each other, more often slightly zigzagging than straight; higher order reticulations and areoles well-developed, visible with a hand lens; lamina subglabrous, with many glands, mostly visible abaxially, drying darker than rest of lamina surface, slightly pitted, $\pm 0.1 \mathrm{~mm}$ in diam.; tufts of hairs present in the axils at the base of the 3 main veins; petiole slightly dorsiventrally flattened, (1 -) $2-5 \mathrm{~mm}$ long, hairs dense, indumentum extending to widened base of main veins adaxially. Inflorescence of axillary pedunculate cymes, c. 7 flowers in each cyme, cymes loose dichasia visibly branching $1-2$ times; peduncles dorsiventrally flattened (2 -) $5(-10) \mathrm{mm}$ long, hairs dense, spreading, c. $0.1 \mathrm{~mm}$ long; pedicels c. $1 \mathrm{~mm}$ long, straight; bracteoles entire, narrowly triangular, c. $1 \mathrm{~mm}$ long, hairs dense. Flower hypanthium densely hairy abaxially, c. $0.1 \mathrm{~mm}$ long, appressed-antrorse, whitish; sepals triangular, c. $1.2 \mathrm{~mm}$ long, yellowishgreen when fresh, glabrous and keeled adaxially; petals clawed, c. $1.2 \mathrm{~mm}$ long, obcordate; stamen filaments flat, subulate, c. $1.0 \mathrm{~mm}$ long, anthers c. $0.3 \mathrm{~mm}$ long, enclosed by petals; nectary disk pentagonal, 10-pitted, glabrous; style arms 2, well-developed, c. $0.7 \mathrm{~mm}$ long, terminating in an expanded, almost flat stigmatic surface; ovary partially immersed, hairs dense. Fruit a drupe, ripening yellowish, flushed reddish, (0.4-) 0.9 $(-1.5) \times(0.3-) 0.8(-1.3) \mathrm{cm}$, (globose - ) obovoid [wider towards apex], indumentum dense, hairs drying reddish, < $0.1 \mathrm{~mm}$ long; fruiting pedicels c. $3 \times 1 \mathrm{~mm}$; hypanthium remains saucer-shaped at base of fruit.

DISTRIBUTION. Borneo (Brunei, Kalimantan, Sabah, Sarawak), Sulawesi. Map 9.
ADDITIONAL SPECIMENS EXAMINED. BRUNEI. BELAIT: Bukit Sawat Jalan Merangking-Buau, 27 July 1996, Kalat et al. BRUN 17692 (K); TEMBURONG: Bukit Belalong, $4^{\circ} 29^{\prime} \mathrm{N} 115^{\circ} 11^{\prime} \mathrm{E}, 900 \mathrm{~m}, 22$ Feb. 1992, Dransfield et al. JD 7157 (K, L); Bukit Belalong, 23 July 1989, Joffre s.n. (K); Headwaters of Temburong R. to the NE of Gunong Retak, 4 $22^{\prime} \mathrm{N} 115^{\circ} 17^{\prime} \mathrm{E}, 900 \mathrm{~m}$, 13 March 1991, Sands et al. 5369 (K, L); Bukit Patoi, 29 Oct. 1989, Wong WKM 1598 (K); TUTONG: Telisai, Bukit Basong, 11 Sept. 1996, Kalat et al. BRUN 17810 (K); INDONESIA. BORNEO: CENTRAL KALIMANTAN, Sintang. HPH 70, W of camp off main road; along new $\log$ road and surrounding environs towards $\mathrm{Km}$ 71, 051'53.6”S 112¹3'29.9”E, 150 m, 11 April 1994, Church et al. 834 (E, K, L); $10 \mathrm{~km}$ along side road at Km 57 from Sangai (S. Mentaya), Kab. Kotawaringin Timur, $1^{\circ} 29^{\prime} \mathrm{S} 112^{\circ} 31 ' \mathrm{E}$, c. $50 \mathrm{~m}, 20$ Oct. 1994, Wilkie 94312 (E); EAST KALIMANTAN, foot of Gunong Beratus, W of Balikpapan, c. 300 m, 26 Jan. 1979, Murata B 2759 (L); near Gunung Meratus, Orang Utan release site, 0`57'29"S 116 19'43”E, 166 m, 12 Jan. 2005, Slik MEPRI 4529 (L); W Koetai, no. 37, near Mt Kemoel, 27 Sept. 1925, Endert 3607 (K); Sg. Wain, NE of Balikpapan, 90 m, Oct. 1950, Kostermans 4041 (K, L); W Kutei, Kelindjau R. region near Melan, 28 June 1954, Kostermans 9688; Central Kutei, Belajan R. near Long Bleh, 25 March 1955, Kostermans 10234 (K, L); NORTH KALIMANTAN, W Koetai, no. 36, near L. Petah, c. 550 m, 9 Sept. 1925, Endert 3114 (K, L); MALAYSIA. SABAH: Crocker Range F. Res., 25 May 1977, Abas SAN 85693; Mount Kinabalu, Upper Kinabalu, 6000 - $16500 \mathrm{ft}[1800$ - $5000 \mathrm{~m}], 27$ Jan. 1932, Clemens $\mathcal{E}$ Clemens 29324 (L); Penibukan, $4000 \mathrm{ft}$ [1200 m], 10 Nov. 1931, Clemens E Clemens 32195 (L); ibid., Marai Parai, 5000 ft [1500 m], 7 May 1933, Clemens E Clemens 33096 (K); ibid., Penibukan ridge, $4000 \mathrm{ft}$ [1200 m], 23 Sept. 1933, Clemens E Clemens 40420 (K); ibid., Gurulau Spur, $5000 \mathrm{ft}[1500 \mathrm{~m}], 9$ Dec. 1933, Clemens E Clemens 50854 (K, L); KENINGAU, Mile 55 on path from Tenom to Ranau (near Apin-Apin), $2000 \mathrm{ft}$ [600 m], 2 Sept. 1954, Wood Eं Wyatt-Smith A 4387 (L); NABAWAN, Pensiangan, Ponontomon FR, 17 Aug. 1994, Krispinus SAN 136978 (K); RANAU, Mesilau R., 5000 ft [1500 m], 11 April 1964, Chew E Corner RSNB 4894 (K, L); Tenompok, toward Bundu T., $5500 \mathrm{ft}$ [1700 m]; 27 Jan. 1932, Clemens E Clemens 28129 (K); Mount Kinabalu, Tenompok, $5000 \mathrm{ft}[1500 \mathrm{~m}] ; 16$ March 1932, Clemens $\mathcal{E}$ Clemens 28874 (K, L); ibid., Clemens E Clemens 30376 (K, sheet 1); Kinabalu National Park, along Sg. Mamut, 1200 - 1400 m, 15 Feb. 1969, Kokawa Eீ Hotta 5781 (L); Mesilau Camp, 1964, Poore H 441 (K); Kampung Bundu Tuhan. Notoki, Kg. Himbaan, 5 57'4" N 116 33'43”E, 14 April 1993, Soibeh 201 (K); TONGOD, Lamag, S. side of 
Gunong Lotung Inarat, $3200 \mathrm{ft}[1000 \mathrm{~m}], 17$ May 1976, Gibot SAN 83221 (K); Ulu Sg. Pingas, 14 March 1985, Krispinus E Sumbing SAN 110913 (K, L); SARAWAK: 1865 - 68, Beccari 2493 (K); Gat, Upper Rejang [Rajang] R., 1929, Clemens $\mathcal{E}$ Clemens 21688 (K); Rejang [Rajang R.], s.d., Haviland 807 (K); KUCHING, 30 Jan. 1893, Haviland 2134 (K); LIMBANG, Bukit Binula Lawas, 1200 m, 2 Aug. 1895, Rena et al. S.60744 (K); MIRI, Sg. Mentawai, G. Mulu N.P., 6 Oct. 1977, Chai S.39697 (K, L); Kalabit Highlands, Pa Ukat 3 miles E of Bario, 1000 m, 20 April 1970, Nooteboom E Chai 2170 (K, L); Pulong Tau National Park (Western part). Trail to Bukit Tenidan from Napun Kederi (Kern B), 9 May 2007, Suzana et al. S.97545 (K); Sg Kelapang, Ramudu, Bario, 24 March 1997, Wat et al. S.76303 (K); MUKAH, Bkt. Iju, Ulu Sg. Arip, Balingian, 700 ft [200 m], 3 Aug. 1965, Kudi S.23703 (K, L); SAMARAHAN, Gunong Gaharu, Ulu Sg. Sabal Aping, 70th Mile, Serian/Simanggang Rd., Simunjan, 1300 ft [400 m], 12 Oct. 1974, Paie S.35742 (K, L); Sabal F.R., 70th Mile, Serian Road, 13 May 1974, Tong et al. S.34293 (K, L).

HABITAT. Borneo lowland and montane rain forests; alt. $30-1800 \mathrm{~m}$.

CONSERVATION STATUS. Near Threatened (NT). It is likely that the taxon is declining and severely fragmented given the widespread destruction of rainforests in Borneo. However, the taxon is distributed with an EOO greater than 300,000 $\mathrm{km}^{2}$. Also, the species occurs in hilly and montane habitats possibly less exposed to heavy exploitation. Some specimens were collected in the following protected areas: Ulu Temburong National Park (IUCN Category II) in Brunei; Kinabalu National Park and ASEAN Heritage Park (IUCN Category II) in Sabah; Mulu National Park and ASEAN Heritage Park (IUCN Category II) in Sarawak.

PHENOLOGY. Collected in flower in Jan., Feb. and May - Oct.; collected in fruit March - May and July - Dec.

VERNACULAR NAMES. Akar kuku menaul/manayul/ menawal (Iban, fide Chai S.39697, Rena et al. S.60744, Suzana et al. S.97545, Tong et al. S.34293); Akar-sema'it (Berawan, fide Chai S.39697); Kukulang (Iban and Malay, fide Kalat et al. BRUN 17810, Sands et al. 5369); Mensimou (Dusun, fide Soibeh 201).

USES. Fruits edible, sweet (fide Chai S.39697, Soibeh 201 and Suzana et al. S.97545).

NOTES. Ziziphus havilandii is recognised by leaves having abundant dark glands (appearing as black spots) on the abaxial lamina. Only the three main veins are clearly visible and a faint but distinct intramarginal vein running along the leaf margin is present. It is also recognised by the presence of wide ovate, fugaceous stipules c. $3 \times 2 \mathrm{~mm}$ and the spines of distal branchlets spaced by c. $1 \mathrm{~cm}$, closer to each other than in most other species. It most resembles $Z$. suluensis in the black spot, venation and stipule characters. Ziziphus havilandii differs from $Z$. suluensis in the leaves being smaller, usually $2.5-5.5 \times 1.2-2.5 \mathrm{~cm}$, (vs usually $8 \times 3.5 \mathrm{~cm}$ ), chartaceous (vs chartaceous-subcoriaceous), usually more asymmetric and widest near base (vs widest near middle), often denser indumentum on distal branchlets and usually smaller fruits, on average 0.9 $\times 0.8 \mathrm{~cm}$ (vs $1.2-1.5 \times 0.9-1.5 \mathrm{~cm}$ ). The difference between the two species is slight, they could represent a single species on the same morphological variability continuum. Ziziphus suluensis was originally described based on material collected in Tawi-tawi, close to Borneo and the species is not known to occur on more northern islands of the Philippines, also suggesting that $Z$. havilandii and $Z$. suluensis could be a single lineage restricted to Borneo's near vicinity (Sulawesi and southern Philippines). Schirarend (1995) used the character of the intramarginal vein to distinguish the two species (present in Z. havilandii, absent in $Z$. suluensis), but this could not be observed on all available specimens previously identified as $Z$. suluensis, including the type material.

Ridley (1931) cited Beccari 2493 and Haviland 2134 in his protologue for Ziziphus havilandii, and he indicated that the latter specimen is the "type". A sheet of the Haviland 2134 collection is selected here as the lectotype.

9. Ziziphus horsfieldii Miq. (Miquel 1856: 643). Type: Indonesia, Java, 1802 - 1818, Horsfield s.n. (lectotype, selected here: K [K000723025]).

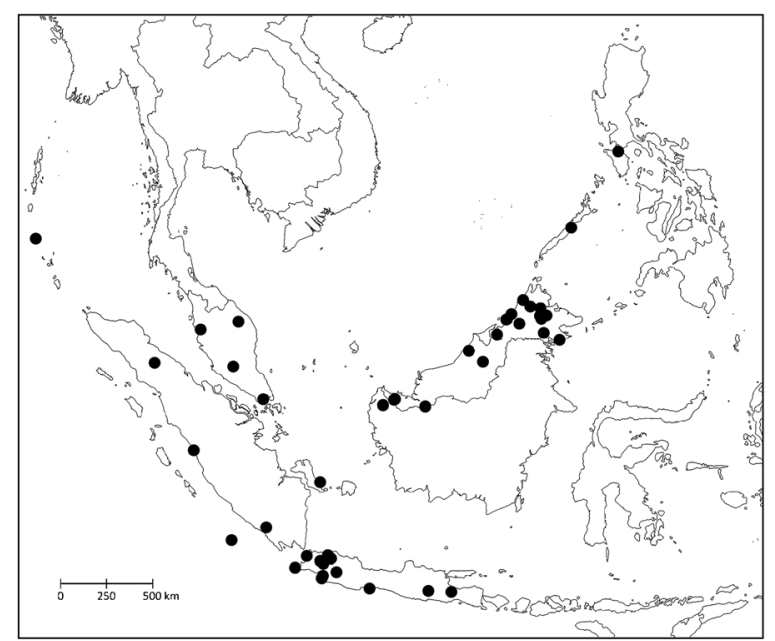

Map 10. Distribution of Ziziphus horsfieldii $(\bullet)$. 
Ziziphus palawanensis Elmer (1913: 1828) synon. nov. Type: Philippines, Palawan, Puerto Princesa (Mt. Pulgar), March 1911, Elmer 12891 (lectotype selected here: A [00051556]; isolectotypes: F [V0068187F], GH [00051555], L [L 0550937], NY [00415113], P [P06790454], U [U 0115267], US [00094337]).

Woody climber to at least $30 \mathrm{~m}$ long; girth to at least $10 \mathrm{~cm}$ in diam., spiny. Branchlets terete, with longitudinal striations and conspicuous, raised lenticels, hairs sparse, c. $0.5 \mathrm{~mm}$ long mixed with shorter hairs $0.1 \mathrm{~mm}$ long, mostly appressedantrorse, reddish to whitish. Stipules modified into spines, single, recurved, c. $2.5 \mathrm{~mm}$ long, subglabrous. Leaves weakly discolorous, drying greenish-brown, blade asymmetric, (lanceolate -) narrow ovate (- ovate), $3.5-10.0 \times 1.2-4.5 \mathrm{~cm}$, chartaceous to subcoriaceous, apex attenuate to acuminate, base cuneate to subcordate, usually clearly oblique, margins finely denticulate, c. 100 serrations on either side, each serration topped by a protruding callosity that dries darker than the lamina, c. $0.1 \mathrm{~mm}$ long; primary veins 3, impressed adaxially, raised abaxially, hairs sparse along primary veins on either side of lamina, often more densely adaxially, hairs c. $0.2 \mathrm{~mm}$ long; strong marginal veins coming off the outside of the two outer main veins c. 6 on either side, rarely $<5$, ascending and gradually diminishing, not forming conspicuous loops near margin, no clear intramarginal vein running along the leaf margin present, angle of divergence with outer main veins c. $45^{\circ}$; transverse veins between the main veins weak but discernible, especially adaxially, coming off midrib at c. $90^{\circ}$, barely raised (not readily felt by touch), spaced by $\mathrm{c}$. $1 \mathrm{~mm}$ from each other, more often slightly zigzagging than straight; higher order reticulations barely discernible; lamina subglabrous; domatia present in the axils at the base of the 3 main veins and at the junction between the marginal veins and the outer main veins, pocket-like and often with tufts of hairs, swelling often visible adaxially just above junction between 3 main veins; petiole slightly dorsiventrally flattened, c. $7 \mathrm{~mm}$ long, hairs dense, indumentum extending to widened base of main veins adaxially. Inflorescence of axillary pedunculate cymes, $<1 / 2$ as long as subtending leaves, c. 12 flowers in each cyme, cymes loose dichasia with usually peduncle and first 2 branches clearly elongate and next 4 branches short but distinct; peduncles dorsiventrally flattened (5-) 10 (- 15) mm long, hairs abundant, mostly < $0.1 \mathrm{~mm}$ long; pedicels c. $2 \mathrm{~mm}$ long, straight to slightly curved; bracteoles entire, narrowly triangular, c. $1 \mathrm{~mm}$ long, hairy. Flower faintly scented; hypanthium densely hairy on the outer surface, hairs $0.1 \mathrm{~mm}$ long, appressed-antrorse, greyish; sepals triangular, c. $1.2 \mathrm{~mm}$ long, pale greenish when fresh, glabrous and keeled adaxially; petals clawed, c. $1 \mathrm{~mm}$ long, obcordate, white; stamen filaments flat, subulate, c. $0.7 \mathrm{~mm}$ long, anthers c. $0.3 \mathrm{~mm}$ long, enclosed by petals; nectary disk yellow, pentagonal, 10-pitted, glabrous, annulus surrounding ovary barely raised; style arms 2, free for c. $1 \mathrm{~mm}$, glabrous; ovary partially immersed, hairs dense. Fruit a drupe, ripening yellowish-green, $(0.9-) 1.1(-1.5) \times(0.7-) 1.1(-1.5) \mathrm{cm}$, obovoid [wider towards apex], indumentum dense, hairs drying reddish, $<0.1 \mathrm{~mm}$ long; fruiting pedicels $\mathrm{c}$. $5 \times 1 \mathrm{~mm}$; hypanthium remains annular at base of fruit.

DISTRIBUTION. Brunei, Indonesia (Java, Kalimantan, Sumatra), Malaysia (Malay Peninsula, Sabah, Sarawak), Philippines (Mindoro, Palawan), Singapore. Map 10.

ADDITIONAL SPECIMENS EXAMINED. BRUNEI. TEMBURONG: Temburong R. just downstream from Kuala Belalong, 25 June 1989, Wong WKM 1281 (K, L); INDONESIA. BORNEO: WEST KALIMANTAN, Sanggouw, 1893 - 1894, Hallier 811 (L); MALAYSIA. SABAH: Hills about Bumi, 1857, Lobb s.n. (K); BEAUFORT, Kampong Suasa Kota Klias, 29 July 1969, Gibot SAN 64377 (K, L); Klias F. Res., 20 July 1973, Sundaling E Karim SAN 77793 (K, L); BELURAN, Bidu-bidu hill, 31 July 1990, Maikin et al. SAN 130679 (E, K); KENINGAU, Kg. Bah Mula Jalan Karamatoi, 19 Oct. 1978, Abas SAN 86009 (K, L); KOTA BeLUd, HS. Purak mato, 19 Aug. 1987, Mansus E Amin SAN 106660 (K); PAPAR, Ulu Bongawan, 9 Sept. 1976, Bidin SAN 84401 (K, L); RANAU, Tompurungon, 17 Oct. 1986, Amin E Jarius SAN 116444 (K, L); SANDAKAN, H.S. Sagaliud Lokan, 24 Aug. 1989, Bousi et al. SAN 124340 (E, K, L); Pembangunan Sabariah Sdn Bhd, Sg Kun-Kun, 7 June 1983, Gibot SAN 96929 (L); HS. Segaliud-Lokan, 30 June 1986, Pikkoh SAN 116849 (K); TAWAU, Mile 26, Imbak Rd., Luasong, 11 Dec. 1979, Krispinus $\mathcal{E}^{\circ}$ Sumbing SAN 91399 (K, L); 3 Miles N of Balong Estate, 5 Dec. 1963, Meijer 41042 (K, L); TENOM, Sungai Kaang, 25 March 1987, Mantor SAN 120247 (K); TONGOD, Sg Tangkulap, 25 June 1983, Amin SAN 97402 (K, L); SARAWAK: KAPIT, Belaga, Ulu Sg, Berangan, Batang Balui, Bakun HEP, 520 m, 23 Aug. 1995, Yii et al. S.72598 (L); KUCHING, Jambusan, $300 \mathrm{ft}[10 \mathrm{~m}]$, 24 July 1960, Anderson 12585 (K, L); Seburan, 100 ft [30 m], 29 May 1960, Anderson 12908 (K, L); Bkt. Tabai, Tai Ton Bau, $400 \mathrm{ft}[100 \mathrm{~m}], 16$ Dec. 1965, Chai S.22874 (K, L); MIRI, Ulu Sungei Sekaloh, Niah R., 1 Dec. 1966, Anderson S.27284 (K, L); Baram, Dec. 1894, Hose 169 (E, K, P); ibid., 12 April 1895, Hose 698 (E, K); 
Long Dam, Ulu Dapoi, Tinjar, Marudi, 1000 ft [300 m], 10 April 1965, Luang S.23451 (K, L).

HABITAT. Borneo lowland rain forests; alt. $30-520$ $\mathrm{m}$.

CONSERVATION STATUS. Least Concern (LC). Ziziphus horsfieldii is widely distributed in western Malesia and extends to the Philippines. It does not appear to be threatened. In Borneo, it could be declining and severely fragmented given recent widespread destruction of rainforests but was collected in the following protected areas in Sabah: Bidu-Bidu Protection Forest Reserve (IUCN Category Ia), Klias Protection Forest Reserve (IUCN Category not reported) and SG. Kinabatangan Valley Bird Sanctuary (IUCN Category not reported).

PHENOLOGY. Collected in flower in April, June, Oct. and Dec.; collected in fruit in March, June - Oct. and Dec.

VERNACULAR NAMES. Kanggom sopuan (Sandakan, fide Bousi et al. SAN 124340); Kuku menaul (Iban, fide Luang S.23451); Unak Menaul (Iban, fide Wong WKM 1281).

USES. No recorded uses found.

NOTES. In Borneo, Ziziphus horsfieldii is most like Z. cuspidata and Z. domatiata in having pedunculate cymes, fruits $<1.5 \times$ longer than wide, leaves usually $<$ $7 \times 3 \mathrm{~cm}$ with usually $<8$ strong marginal veins coming off the outer main veins on either side. It differs from both species in the densely hairy fruits (vs glabrous). It also differs from Z. cuspidata in the smaller fruits, c. 1.1 $\times 1.1 \mathrm{~cm}$ (vs c. $2 \times 1.5 \mathrm{~cm}$ ), the leaf lamina being subglabrous abaxially except along larger veins (vs usually hairy), the longer petioles, c. $10 \mathrm{~mm}$ (vs $3-7$ $\mathrm{mm}$ ) and the often clear presence of tufts of hairs at the junction between the outer main veins and the marginal veins. It further differs from $Z$. domatiata in the obovoid fruits (vs subglobose) and leaves with c. 6 strong marginal veins on either side (vs. c. 4).

The type material from Java is unusual in having almost subsessile fruits but does not appear to differ in any other morphological character from material recognised here as Ziziphus horsfieldii. A lectotype is selected here among the Horsfield material collected in Java. Two additional sheets of $Z$. horsfieldii from Java marked as belonging to Horsfield's herbarium are available at K (K000723024, K000723026) but whether these are isolectotypes, i.e. from the same collection event as the lectotype, is unsure.

Ziziphus palawanensis Elmer is placed as a synonym here because no apparent morphological character from the type material or protologue description seems to separate it from Z. horsfieldii. Elmer (1913) described the climber as forming "dense hanging masses over the open creek bed". Elmer 12891, indicated as the type in the protologue for Z. palawanensis (Elmer op. cit.), is widely distributed with duplicates available in at least seven herbaria. and the sheet at A, where much of Elmer's herbar-

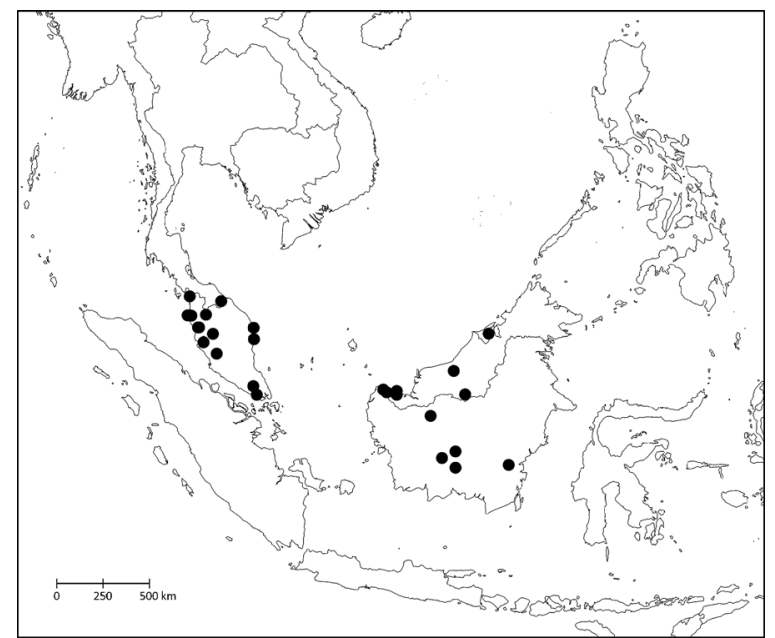

Map 11. Distribution of Ziziphus kunstleri $(\bullet)$.

ium collections are kept, is selected here as the lectotype.

10. Ziziphus kunstleri King (1896: 373). Type: Malaysia, Penang, Province Wellesley [Seberang Perai], April 1881, King's Collector [Kunstler] 1607 (lectotype, selected here: K [K001420133]; isolectotype: CAL [24069]). Lectoparatypes: Malaysia, Perak, May 1888, Wray 1911 (CAL [24072], P [P06784156]); Wray 3281 (not seen); Perak, s.d., Wray 3285 (L [L.2328519]); ibid., Larut [Taiping], Jan. 1883, King's Collector [Kunstler] 3772 (CAL [24070], P [P06784154, P06784155], US [3364315]); ibid., Nov. 1881, King's Collector [Kunstler] 6853 (CAL [24071]).

Ziziphus cupularis Suess. \& Overkott (Suessenguth \& Overkott 1941: 330) synon. nov. Type: Malaysia, Sarawak, s.d., Native collector 113 (lectotype, selected here: K [K000723022]; isolectotypes: A [00051549], L [L 0013799]).

Woody climber to at least $9 \mathrm{~m}$ long; girth to at least $10 \mathrm{~cm}$ in diam., spiny. Branchlets terete, with longitudinal striations and superficial lenticels concealed by indumentum, densely hairy on young parts and distal portions, more sparsely hairy when mature, hairs c. $0.5 \mathrm{~mm}$ long mixed with shorter hairs, mostly spreading on inflorescence rachis, reddish, some whitish. Stipules 1 or 2 per node, forming clusters at the tip of developing shoots, 1 stipule modified into a spine, recurved, c. $4 \mathrm{~mm}$ long, other stipule erect, not spine-like, c. $4 \mathrm{~mm}$ long [Wilkie 94133]. Leaves weakly discolorous, drying greenish-brown, paler abaxially, chartaceous, dimorphic: first type type of leaf proximal to inflorescences, blade symmetric, (wide) ovate-elliptic, $6.0-17.7 \times 4.7-9.8 \mathrm{~cm}$, 
apex rounded to acuminate, base rounded to cordate, symmetric, margins entire to serrate, c. 70 serrations on either side, each serration topped by a minute protruding callosity that dries darker than the lamina, c. $0.1 \mathrm{~mm}$ long; primary veins 3, impressed adaxially, raised abaxially, hairs abundant along primary veins abaxially, hairs c. $0.7 \mathrm{~mm}$ long, \pm straight, \pm spreading; strong marginal veins coming off the outside of the two outer main veins $>20$ on either side, \pm equally strong, ascending and forming loops near the margin but no clear intramarginal vein running along the leaf margin, angle of divergence with outer main veins $40-70^{\circ}$; transverse veins between the main veins conspicuous, coming off midrib at $50-$ $90^{\circ}$, raised (readily felt by touch), spaced by c. $5 \mathrm{~mm}$ from each other, slightly zigzagging, often branching; higher order reticulations discernible, slightly raised; lamina sparsely hairy abaxially (more densely along bigger veins), hairs c. $0.3 \mathrm{~mm}$ long, mostly spreading; domatia present in the axils at bigger veins with main veins, pocket-like; petiole slightly dorsiventrally flattened, (2 -) 4 (- 10) mm long, hairs dense, indumentum extending to widened base of main veins adaxially. Second type of leaf smaller, at the base of cymes, fugaceous, narrowly ovate, c. $5 \times 2 \mathrm{~cm}$, apex acute to attenuate. Inflorescence of axillary pedunculate cymes subtended by fugaceous leaves, ultimately arranged in a panicle, $<1 / 2$ as long as subtending leaves, c. 7 flowers in each cyme, cymes contracted dichasia not or only once visibly branching; peduncles 2-10 $\mathrm{mm}$ long, hairs dense, reddish, spreading; bracteoles entire to deeply bifid, narrowly triangular, c. $3 \mathrm{~mm}$ long, hairy. Flower hypanthium densely hairy on the outer surface; sepals triangular, pale yellow, c. $2 \mathrm{~mm}$ long, glabrous and keeled adaxially; petals clawed, c. $2.5 \mathrm{~mm}$ long, obcordate; stamen filaments flat, subulate, c. $2 \mathrm{~mm}$ long, anthers c. $0.4 \mathrm{~mm}$ long, enclosed by petals; nectary disk, pentagonal, 10pitted, glabrous; style arms 2, well-developed, c. $0.8 \mathrm{~mm}$ long, diverging, not expanding at apex, glabrous ovary partially immersed, hairs dense. Fruit a drupe, ripening with a velvety brown tinge, ellipsoid, often with a flattened base, c. $(2-) 3 \times$ $(1.5-) 1.8 \mathrm{~cm}$, indumentum dense, hairs drying reddish-brown, hypanthium remains at base of fruit visible, saucer-like, calyx lobes often persistent and reflexed.

DISTRIBUTION. Borneo (Brunei, Kalimantan, Sarawak), Peninsular Malaysia, Thailand (Narathiwat, Yala). Map 11.
ADDITIONAL SPECIMENS EXAMINED. BRUNEI. TUTONG: Ulu Supon, 40 ft [10 m], 10 Jan. 1958, Ashton BRUN 867 (K, L); INDONESIA. CENTRAL KALIMANTAN: Km 15 on road from camp 48. Sangai, S. Mentaya, Kab. Kotawaringin Timur, $1^{\circ} 29^{\prime} \mathrm{S} 112^{\circ} 31^{\prime} \mathrm{E}$, c. $50 \mathrm{~m}, 30$ March 1995, Latupeirissa 95006 (E, K); km 4 from Sangai, S. Mentaya, Kab. Kotawaringin Timur, $1^{\circ} 29^{\prime} \mathrm{S} 112^{\circ} 31^{\prime} \mathrm{E}$, c. $50 \mathrm{~m}, 10$ March 1994, Wilkie 94133 (E, K); Bukit Raya, Tumbang Riang, 8 Jan. 1983, Wiriadinata 3199 (L); EAST KALIMANTAN: P.T. ITCI, road Kenangan to G. Meratus, km 54, 400 m, 27 March 1995, Kessler et al. 911 (K, L); WEST KALIMANTAN: Smittouw, 1893 - 94, Hallier 1351 (L, U); MALAYSIA. SARAWAK: Nov. 1871, Beccari 3377 (K); BINTULU, Sungei Mayeng, Tau Range, $500 \mathrm{ft}$ [150 m], 7 June 1956, Purseglove P.5407 (K, L); KAPIT, Naanga Sringin, Ulu Sungai Entuloh, Baleh, 2 Aug. 1995, Othman et al. S.57743 (K); KUCHING, Gunung Pueh, 200 m, 5 March 1992, Ching et al. S.64312 (K); Mount Poi base, 5 Oct. 1929, Clemens E् Clemens 7253 (K); Garai, 4 Dec. 1892, Haviland 884 (K); Near base of Santubong, 23 Feb. 1949, Sinclair Singapore Field No. 38323 (E, K, L).

HABITAT. Borneo lowland rain forests; alt. 10 - 400 $\mathrm{m}$.

CONSERVATION StATUS. Near Threatened (NT). It is likely that the taxon is declining and severely fragmented given the widespread destruction of rainforests in Borneo and the Malay Peninsula. However, the taxon is distributed with an EOO greater than $350,000 \mathrm{~km}^{2}$. Some specimens were collected in or near the following protected areas: Gunong Gading National Park (IUCN Category II) and Santubong National Park (IUCN Category not reported) in Sarawak, and Budo-Sungai Padi National Park (IUCN Category II) in Thailand.

PHENOLOGY. Collected in flower in June; collected in fruit in Jan. - March, Aug., Nov. and Dec.

VERNACULAR NAMES. Akar duri menawal (Iban, fide Ashton BRUN 867); Duri (Indonesian, fide Wilkie 94133).

USES. Fruits edible (fide Ching et al. S.64312 and Othman et al. S.57743).

NOTES. Ziziphus kunstleri is recognised in the dense reddish indumentum on the branchlets and inflorescence, large ovate leaves, to $17.7 \times 9.8 \mathrm{~cm}$, densely hairy abaxially, pedunculate cymes and big fruits, c. $3 \times 1.8 \mathrm{~cm}$, ellipsoid, brownish. Ziziphus kunstleri is most easily confused vegetatively with Z. crebrivenosa because of the similar leaf size and marginal veins coming off the outside of the two outer main veins forming several loops near the margin. However, leaves of Z. kunstleri have raised veins, including in smaller reticulations, and the transverse veins between the main veins tend to branch (vs finer reticulations not clearly raised 
and transverse veins tend to join the main veins without branching in Z. crebrivenosa). In addition, branchlets of $Z$. kunstleri have superficial lenticels concealed on younger parts by the dense reddish indumentum (vs lenticels conspicuous and raised in Z. crebrivenosa). Both species occur in Borneo, but their distribution is not known to overlap elsewhere.

King (1896) specified naming the species "in memory of its first collector, H. H. Kunstler, who sent it from Province Wellesley in 1881" and lists King's Collector [Kunstler] 1607 as illustrative material in his protologue for Ziziphus kunstleri. A sheet of this material is available at $\mathrm{K}$, which holds King's main sets, and is selected here as the lectotype.

Ziziphus cupularis type material does not appear to differ from Z. kunstleri. In the protologue notes for Z. cupularis, Suessenguth \& Overkott (1941) indicated that both species are similar but that Z. kunstleri differs in having axillary inflorescences and a hypanthium that is not cup-shaped. In Z. kunstleri, inflorescences are indeed subtended by leaves at an early stage, but these leaves, which are distinctly smaller than more proximal leaves, soon fall and inflorescences then are paniculate as in the type material for Z. cupularis. The hypanthium appears cup-shaped on most Z. kunstleri material as it does in the type material for Z. cupularis, but this is no longer obvious in specimens with fully open flowers, such as King's Collector 1607. Suessenguth \& Overkott cited Native Collector 113 in the protologue for Z. cupularis. Suessenguth worked in $\mathrm{M}$ and a sheet with a drawing of the flower of this collection, but no plant material, and referring to material in B, is available at M [M0211790]. Suessenguth \& Overkott (op. cit.) also specified that the material they studied was provided by $\mathrm{B}$. The type therefore used to be there and it is most likely that it was destroyed in the 1943 fire (Merrill 1943). The sheet at K, which includes open flowers, is selected here as the lectotype.

Surprisingly, Ziziphus kunstleri was not included in the list of Ziziphus species occurring in Sabah and Sarawak by Schirarend (1995), despite being cited by Beaman \& Anderson (2004), Masamune (1942) and Ridley (1931).

11. Ziziphus puberula Cahen $\mathcal{E}$ Utteridge sp. nov. Type: Brunei, Temburong District, Sungai Temburong at Kuala Belalong, 4³2'N 1159'E, 25 m, 22 June 1989, Dransfield E Boyce 6667 (holotype: K [K001420134]).

http:/ /www.ipni.org/urn:lsid:ipni.org:names:77218845-1
Ziziphus borneensis sensu Beaman \& Anderson (2004: 275), pro parte, non Merr.

Woody climber to at least $8 \mathrm{~m}$ long; girth to at least $30 \mathrm{~cm}$ in diam., spiny. Branchlets terete, with longitudinal striations and visible lenticels, abundantly hairy on young parts and distal portions, more sparsely hairy when mature, hairs very short, $<0.1 \mathrm{~mm}$ long, mostly appressed-antrorse, reddish, some whitish. Stipules modified into spines, single, recurved, c. $5 \mathrm{~mm}$ long, conspicuously decurrent for c. $8 \mathrm{~mm}$ along branchlets, with very short hairs except at tip. Leaves weakly discolorous, drying greenish-brown, blade usually asymmetric, narrow ovate, $4.5-13.5 \times 1.5-6.0 \mathrm{~cm}$, chartaceous to subcoriaceous, apex attenuate to acuminate, base (obtuse -) rounded (- subcordate), symmetric, sometimes weakly oblique, margins entire, with minute callosities that dry much darker than the lamina, occasionally protruding and c. $0.1 \mathrm{~mm}$ long, margin slightly thickened, glabrous; primary veins 3, impressed adaxially, raised abaxially, hairs minute, $0.1 \mathrm{~mm}$ long, abundant along primary veins abaxially, mostly antrorse, reddish; strong marginal veins coming off the outside of the two outer main veins $>10$ on either side (rarely $>12$ ), ascending and forming loops near the margin but no clear intramarginal vein running along the leaf margin, angle of divergence with outer main veins c. $45^{\circ}$; transverse veins between the main veins conspicuous, coming off midrib at $\mathrm{c}$. $90^{\circ}$, raised (readily felt by touch), spaced by $1-2 \mathrm{~mm}$ from each other, more often slightly zigzagging than straight, often branching; higher order reticulations discernible; lamina subglabrous abaxially except along larger veins, hairs minute, $<0.1 \mathrm{~mm}$ long, reddish; domatia present in the axils at the base of the 3 main veins, pocket-like; petiole slightly dorsiventrally flattened, (2 -) 4 (- 6) $\mathrm{mm}$ long, hairs dense, indumentum extending to widened base of main veins adaxially. Inflorescence of axillary pedunculate cymes, < $1 / 2$ as long as subtending leaves, c. 15 flowers in each cyme, cymes loose dichasia with usually 4 terminal elongate branches visible; peduncles 3-10 mm long, hairs abundant, $<0.1 \mathrm{~mm}$ long; pedicels to $5 \mathrm{~mm}$ long, often curved; bracteoles entire, narrowly triangular, c. $1 \mathrm{~mm}$ long, hairy. Flower fragrant (fide de Vogel 1774 and Dransfield E Boyce 6667); hypanthium densely hairy on the outer surface, hairs $<0.1 \mathrm{~mm}$ long, appressed-antrorse; sepals triangular, c. $1.5 \mathrm{~mm}$ long, greenish when fresh, glabrous and keeled adaxially; petals clawed, c. $2 \mathrm{~mm}$ long, obcordate, with a dark medial line; stamen filaments flat, subulate, c. $1.2 \mathrm{~mm}$ long, anthers c. $0.5 \mathrm{~mm}$ long, enclosed by petals; nectary disk yellowish, pentagonal, 10-pitted, glabrous, annulus surrounding ovary strongly raised; style arms 2, free for c. $1 \mathrm{~mm}$, glabrous; ovary partially immersed, hairs dense. Fruit a drupe, ripening yellow, c. $3 \times 1.7$ 
cm, ellipsoid, with flattened base and acuminate apex, surface wrinkly when dry, covered in minute reddish hairs, < $0.1 \mathrm{~mm}$ long; fruiting pedicels curved, c. $5 \times 2$ $\mathrm{mm}$, hypanthium remains caving in at base of fruit. Fig. 4.

RECOGNITION. The species resembles Ziziphus kunstleri and Z. borneensis in the ellipsoid fruits, c. $3 \mathrm{~cm}$ long, but differs in having pedunculate cymes, subtended by leaves that are morphologically indistinct from other leaves (in $Z$. borneensis cymes are few-flowered, subsessile and fascicle-like, and in Z. kunstleri cymes are ultimately arranged in panicles, earlier subtended by fugaceous leaves that are distinctly smaller and narrower than other leaves); it also differs in the indumentum of minute hairs, $<0.1 \mathrm{~mm}$ long, scarcely visible to the naked eye on branchlets, leaf veins and inflorescences (vs conspicuous in $Z$. borneensis and Z. kunstleri). Unlike Z. kunstleri, there are no prominent raised longitudinal venules between the transverse veins that join the main veins.

DISTRIBUTION. Borneo (Brunei, Kalimantan, Sabah, Sarawak), possibly endemic. Map 12.

ADDITIONAL SPECIMENS EXAMINED. BRUNEI. TEMBURONG: Below junction of Temburong and Belalong Rs, $4^{\circ} 34^{\prime} \mathrm{N} 115^{\circ} 09^{\prime} \mathrm{E}, 75 \mathrm{~m}, 23$ March 1991, Johns et al. 6967 (K, L); Sungai Temburong at Kuala Belalong, $4^{\circ} 32^{\prime} \mathrm{N} 115^{\circ} 09^{\prime} \mathrm{E}, 25 \mathrm{~m}, 22$ June 1989, Dransfield Eं Boyce 6667 (K, L); INDONESIA. BORNEO: EAST KALIMANTAN, Wanariset Research, Inhutani Road Semoi, km 11, 70 m, 2 Feb. 1991, Ambriansyah E Arifin W639 (K, L); Valley between limestone hills, N part of Meratus Mts, $1^{\circ} 49^{\prime} \mathrm{S} 115^{\circ} 44^{\prime} \mathrm{E}, 400 \mathrm{~m}, 22$ Oct. 1972, de Vogel 1774 (K, L); W Koetai, no. 33/34, near L. Petah, c. 400 m, 6 Sept. 1925, Endert 4061 (K, L); MALAYSIA, SABAH: Upper Kinabalu, 6000 - $13500 \mathrm{ft}$ [1800 - 4100 $\mathrm{m}$ ], 1931 - 1932, Clemens E Clemens 26722 (K); KALABAKAN, Mile 44 Luason Yen Foh Rd., 6 Aug. 1983, Simbut SAN 100309 (K, L); KENINGAU, Sg. Tumpason, 11 Sept. 1982, Amin SAN 95475 (K, L); KINABATANGAN, Beside Bot Tai Fr., 1 Feb. 1988, Joseph et al. SAN 123665 (K); Pin Supu FR, 5 29'30"N $117^{\circ} 58^{\prime} 00 " \mathrm{E}, 30$ Oct. 2007, Pius et al. SAN 149351 (K); MOSTYN, Sapang Ayer Forest Reserve, June 1966, Sinanggul SAN 57017 (L); PITAS, Paitan FR., 19 May 1987, George $\mathcal{E}$ Amin SAN 121297 (K); SARAWAK: MIRI, Baram, 2 Nov. 1914, Moulton 46 (K); Melinau Gorge, Mulu National Park, 100 m, 23 March 1990, Yii E Talib S.58894 (K).

HABITAT. Borneo lowland and montane rain forests; alt. 25 - $1800 \mathrm{~m}$.

CONSERVATION STATUS. Near Threatened (NT). It is likely that the taxon is declining and severely fragmented given the widespread destruction of rainforests in Borneo. However, the taxon is distributed with an EOO greater than 200,000 $\mathrm{km}^{2}$. Also, the species occurs in montane forests possibly less exposed to heavy exploitation. Some specimens were collected in or near the following protected areas: Ulu Temburong National Park (IUCN Category II) in Brunei; Bukit Soeharto Grand Forest Park (IUCN Category VI) in Kalimantan; Kinabalu National Park and ASEAN Heritage Park (IUCN Category II) in Sabah; Mulu National Park and ASEAN Heritage Park (IUCN Category II) in Sarawak.

PHENOLOGY. Collected in flower in Feb., March, May, June and Sept. - Nov.; collected in fruit in Feb., March, June, Aug. and Sept.

ETYMOLOGY. Named puberula for its minute hairs, scarcely visible to the naked eye, especially along the main veins on the abaxial side of leaves and on fruits.

VERNACULAR NAMES. Kukulan (Iban, fide Dransfield $\mathcal{E}^{\circ}$ Boyce 6667).

USES. No recorded uses found.

NOTES. Ziziphus puberula is not known to occur outside Borneo, where it had hitherto been identified as $Z$. borneensis and $Z$. horsfieldii in herbaria. The fruits are similar in size and shape to those of $Z$. borneensis, but in addition to the pedunculate cymes (vs few-flowered, subsessile and fascicle-like cymes) (Fig. 4F), the discreet puberulent indumentum on the branchlets and leaves of Z. puberula (Fig. 4E) contrasts strongly with the conspicuous dense ferruginous indumentum of Z. borneensis (Fig. 1D \& E). Ziziphus horsfieldii also has pedunculate cymes, but $Z$. puberula differs in the leaves having $>10$ strong marginal veins coming off the outside of the two outer main veins on either side, forming loops near the

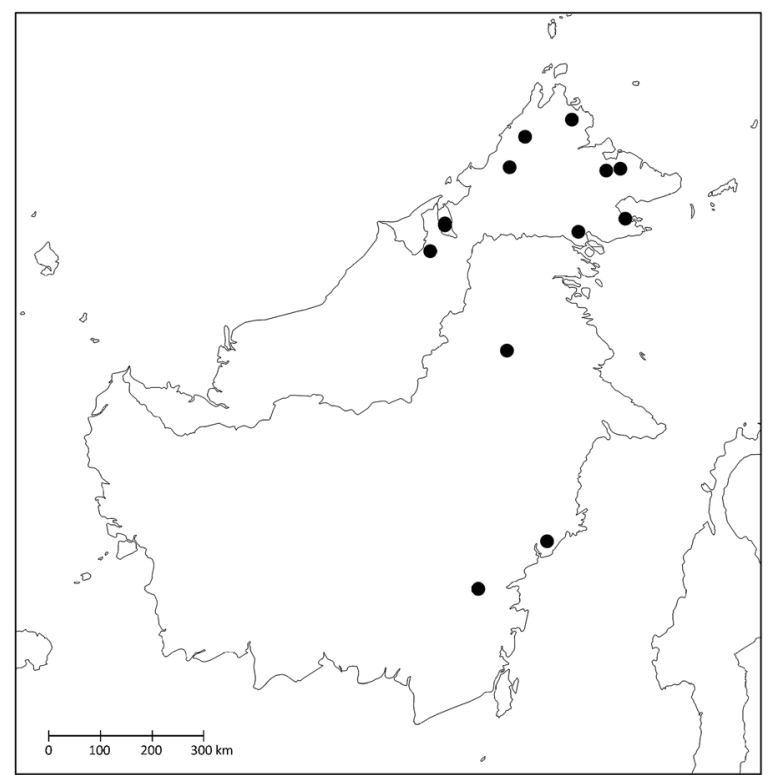

Map 12. Distribution of Ziziphus puberula $(\bullet)$. 


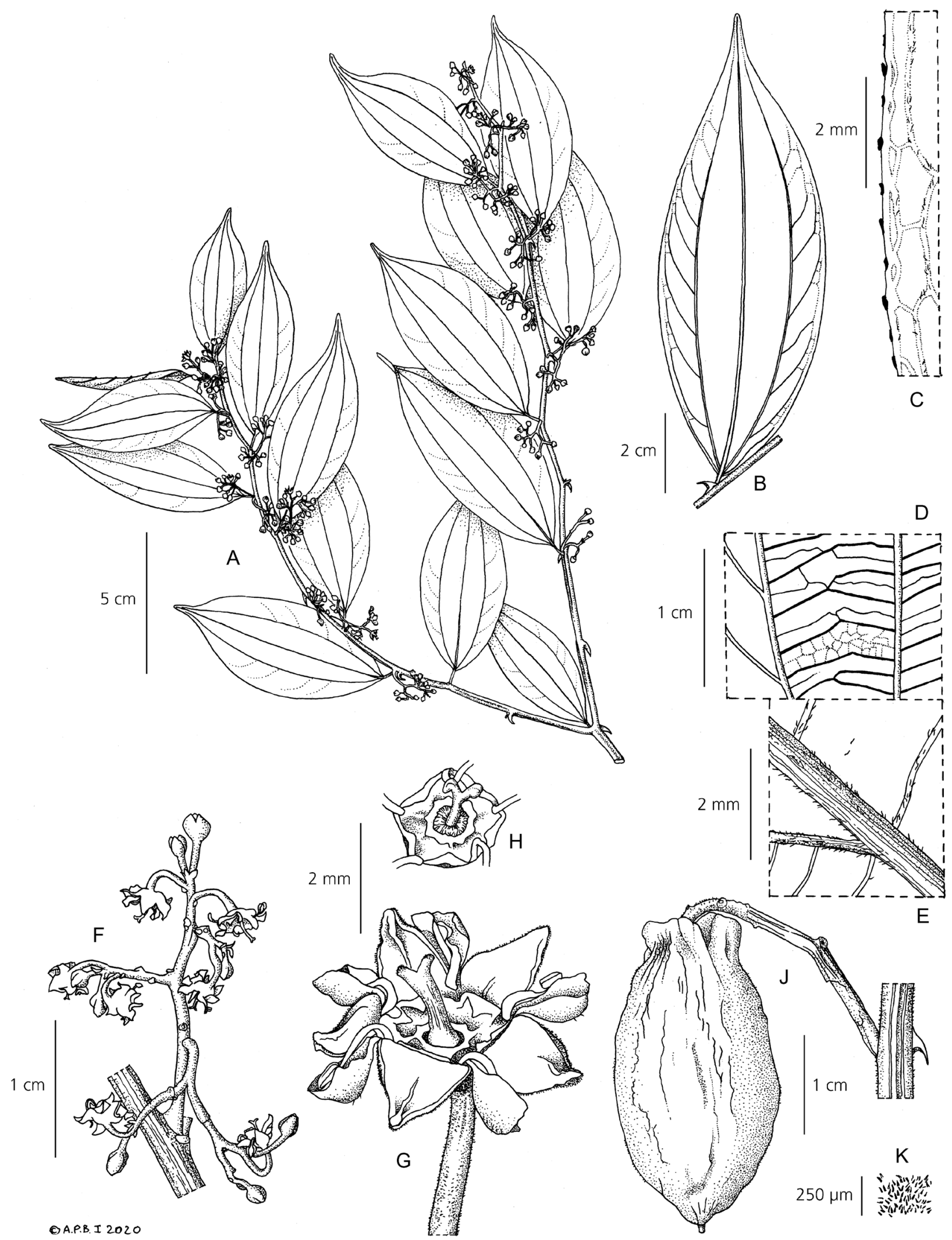

Fig. 4. Ziziphus puberula. A habit; B leaf (scalariform venation omitted), abaxial view; C leaf margin, abaxial view; D leaf lamina surface, abaxial view; E detail of indumentum on leaf lamina surface, abaxial view; F inflorescence (dry); G flower (rehydrated); $\mathrm{H}$ flower centre, viewed from above; J fruit; $\mathrm{K}$ detail of indumentum of fruit surface. A from Endert 4061; B - H from Dransfield \& Boyce 6667; J, K from Simbut SAN 100309. DRAWN BY ANDREW BROWN. 
margin (vs c. 6, ascending and gradually diminishing, not forming conspicuous loops near margin) (Fig. 4B) and the ellipsoid and bigger fruits, c. $3 \times 1.7 \mathrm{~cm}$ (vs obovoid fruits c. $1.1 \times 1.1$ cm) (Fig. 4J).

12. Ziziphus ridleyana Rasingam EF Karthig. (Rasingam \& Karthigeyan 2020: 71). Type: Malaysia, Sarawak, Lundu, s.d. Garai [Haviland's collector] 881 (holotype: K [K000723014], isotype: K [K000723013]).

三 Ziziphus macrophylla Ridl. (Ridley 1931: 494),

nom. illeg. Type: Malaysia: Sarawak, Lundu, s.d., Garai [Haviland's collector] 881 (lectotype, selected here: K [K000723014]; isolectotype: K [K000723013]).

Tree, small [height not measured but plant described as "small tree" on lectotype label], unarmed. Crown, bole, bark, sapwood and heartwood features unknown. Branchlets terete, with longitudinal striations and visible lenticels, densely hairy on young parts and distal portions, more sparsely hairy when mature, hairs c. $0.3 \mathrm{~mm}$ long, mostly spreading, curved, reddish-brown. Stipules not transformed into spines, early deciduous, narrowly triangular, c. $7 \mathrm{~mm}$ long, densely hairy. Leaves weakly discolorous, drying greenish-brown, blade \pm symmetric, elliptic-oblong, $14-31 \times 3.5-11 \mathrm{~cm}$, chartaceous to subcoriaceous, apex attenuate to acuminate, base obtuse to rounded, \pm symmetric, margins subentire, obscurely serrate, each serration topped by a minute protruding callosity that dries darker than the lamina, c. $0.1 \mathrm{~mm}$ long; primary veins 3, impressed adaxially, raised abaxially, hairs dense along primary veins abaxially, hairs c. $1 \mathrm{~mm}$ long curved to tortuous, spreading to antrorse, reddish some whitish; strong marginal veins coming off the outside of the two outer main veins 30 on either side, all ending in a distinct intramarginal vein running along the leaf margin, angle of divergence with outer main veins c. $65^{\circ}$; transverse veins between the main veins conspicuous, also coming off midrib at c. $65^{\circ}$, raised (readily felt by touch), spaced by c. 5 (-15) mm from each other; higher order reticulations visible; lamina hairy abaxially, hairs abundant; no domatia visible; petiole subterete, 5 - $15 \mathrm{~mm}$ long, hairs dense, indumentum extending to widened base of main veins adaxially. Inflorescence of axillary short-peduncled, almost fascicle-like cymes, usually c. as long as subtending leaf's petiole, 6 - 12 flowers in each cyme; pedicels to 4 $\mathrm{mm}$, hairs dense; bracteoles entire, narrowly triangular, c. $5 \mathrm{~mm}$ long, hairy. Flower hypanthium densely hairy on the outer surface; sepals triangular, c. $4 \mathrm{~mm}$ long, glabrous and keeled adaxially; petals clawed, c. $2 \mathrm{~mm}$ long, obcordate; stamen filaments flat, subulate, c. $2 \mathrm{~mm}$ long, anthers c. $0.4 \mathrm{~mm}$ long, exceeding petals; nectary disk pentagonal, rugose, appearing \pm 20-pitted, glabrous, annulus strongly raised and sheathing style; style arms 3, c. $0.5 \mathrm{~mm}$ long, diverging, not expanding at apex, glabrous; ovary partially immersed. Fruit unknown.

DISTRIBUTION. Borneo (Sarawak), only known from vicinity of Mount Pueh. Map 8.

ADDITIONAL SPECIMENS EXAMINED. MALAYSIA. SARAWAK: KUCHING, Mount Poi [Mount Pueh], $2000 \mathrm{ft}$ [600 m], 4 Oct. 1929, Clemens E Clemens 7229 [20144] (K, 2 sheets).

HABITAT. Borneo rain forest; alt. c. $600 \mathrm{~m}$. CONSERVATION STATUS. Endangered (EN). Ziziphus ridleyana is only known from 2 collections in the Mount Pueh, Lundu area (the most recent from 1929) and Borneo rainforests have been declining in extent and quality. The species thus meets the Blab(iii) criteria for EN status. Mount Pueh forests seem relatively well preserved on satellite imagery and Haviland's collection may have been within Gunong Gading, an IUCN Category II (National Park) area.

PHENOLOGY. Collected in flower in Oct.

NOTES. Ziziphus ridleyana is most like $Z$. angustifolia in being a tree without spines but differs in the dense reddish-brown indumentum, covering the branchlets and abaxial surface of leaves (vs glabrous to sparsely hairy leaves, hairy on the main veins only) and bigger flowers, the sepals being $\mathrm{c}$. $4 \mathrm{~mm}$ long (vs c. $2 \mathrm{~mm}$ long).

This species was originally published by Ridley as Ziziphus macrophylla (1931), but the name is an illegitimate later homonym of the fossil name Z. macrophylla (Ettingsh.) Schimp. (Schimper 1874: 224), following Art. 53.1 of the ICN (Shenzen Code) (Turland et al. 2018). The matter was addressed by Rasingam \& Karthigeyan (2020) who published the new name $Z$. ridleyana to replace the illegitimate combination. Two sheets of the same collection by Garai are available at K (K000723013 and K000723014) but only one of them, the holotype, is mentioned in the $Z$. ridleyana protologue (K0007230134). The date of collection of the holotype is indicated to be August 1892 in the protologue, but its label does not specify a date. The label of the isotype (K000723013) reads 'Rec'. aug 1892', which is the date the specimen was received rather than collected. Ridley (op. cit.) surprisingly compares it to the much different $Z$. borneensis, which is a spiny climber rather than Z. inermis (= Z. angustifolia). Ziziphus macrophylla (= Z. ridleyana) is not cited in the Tree Flora of Sabah and Sarawak (Schirarend 1995). 
13. Ziziphus suluensis Merr. (Merrill 1926: 408). Type: Philippines, Sulu Archipelago, Tawi-Tawi, 5 Aug. 1924, Ramos E Edaño Bur. Sci. 44295 (lectotype, selected here: UC [UC257342]; isolectotypes: A [00051557], K [K000723019], P [P06790382], US [00094345]).

Ziziphus havilandii sensu Beaman \& Anderson (2004: 276), pro parte, non Ridl.

Woody climber to at least $15 \mathrm{~m}$ long, girth not recorded, spiny. Branchlets terete, with longitudinal striations and visible lenticels, sparsely to abundantly hairy on young parts and distal portions, becoming sparsely hairy to glabrous when mature, hairs straight to curved, spreading to appressed-antrorse. Stipules paired, one becoming a recurved spine, c. $3 \mathrm{~mm}$ long, the other one fugaceous, persistent on some flowering branchlets, entire, wide ovate, c. $3 \times 2 \mathrm{~mm}$, hairs dense, spines on distal branchlets often closely spaced, by c. $1 \mathrm{~cm}$. Leaves weakly discolorous, drying greenish-brown, blade asymmetric, (ovate -) elliptic-oblong, (4.5 -) 8 $(-13) \times(1.9-) 3.5(-5.2) \mathrm{cm}$, chartaceous-subcoriaceous, apex attenuate to acuminate, base wide cuneate to subcordate, usually symmetric, margins subentire to finely denticulate, > 100 serrations on either side, each serration topped by a protruding callosity that dries darker than the lamina, c. $0.1 \mathrm{~mm}$ long; primary veins 3, impressed adaxially, raised abaxially, hairs sparse to dense along primary veins on either side of lamina, hairs c. $0.2 \mathrm{~mm}$ long; strong marginal veins coming off the outside of the two outer main absent (only 3 main veins conspicuous), faint intramarginal vein running along the leaf margin present; transverse veins between the main veins weak but discernible, coming off midrib at c. $90^{\circ}$, barely raised (not readily felt by touch), tightly spaced, usually $<1 \mathrm{~mm}$ from each other, more often slightly zigzagging than straight; higher order reticulations and areoles well-developed, visible with a hand lens; lamina subglabrous, with many glands, mostly visible abaxially, drying darker than rest of lamina surface, slightly pitted, $\pm 0.1 \mathrm{~mm}$ in diam.; tufts of hairs present in the axils at the base of the 3 main veins; petiole slightly dorsiventrally flattened, $3-7 \mathrm{~mm}$ long, hairs dense, indumentum extending to widened base of main veins adaxially. Inflorescence of axillary pedunculate cymes, sometimes arranged in a panicle, c. 8 flowers in each cyme, cymes loose dichasia visibly branching $1-2$ times; peduncles dorsiventrally flattened $(0.5-) 1.2(-2) \mathrm{cm}$ long, hairs abundant to dense, appressed to spreading, c. $0.1 \mathrm{~mm}$ long; pedicels $(1-) 3(-5) \mathrm{mm}$ long, straight to curved; bracteoles entire, narrowly triangular, c. $1 \mathrm{~mm}$ long, hairs dense. Flower hypanthium densely hairy on the outer surface, c. $0.1 \mathrm{~mm}$ long, appressed-antrorse, reddish; sepals triangular, c. $1.5 \mathrm{~mm}$ long, glabrous and keeled adaxially; petals clawed, c. $1.4 \mathrm{~mm}$ long, obcordate; stamen filaments flat, subulate, c. $1.0 \mathrm{~mm}$ long, anthers c. $0.3 \mathrm{~mm}$ long, enclosed by petals; nectary disk pentagonal, 10-pitted, glabrous; style arms 2, well-developed, c. $0.7 \mathrm{~mm}$ long, terminating in an expanded, almost flat stigmatic surface; ovary partially immersed, hairs dense. Fruit a drupe, ripening yelloworange, $1.2-1.5 \times 0.9-1.5 \mathrm{~cm}$, (globose - ) obovoid [wider towards apex], indumentum dense, hairs drying reddish, < $0.1 \mathrm{~mm}$ long; fruiting pedicels $2-6$ $\times 1 \mathrm{~mm}$; hypanthium remains saucer-shaped at base of fruit.

DISTRIBUtION. Borneo (Brunei, Sabah, Sarawak), Philippines (Sulu). Map 13.

ADDITIONAL SPECIMENS EXAMINED. BRUNEI. TUTONG: Tanjong Maya Bukit Udal Bukit Kukup $4^{\circ} 42^{\prime} \mathrm{N}$ $114^{\circ} 37^{\prime} \mathrm{E}, 100$ m, 22 Dec. 1994, Osman et al. BRUN 16474 (K), MALAYSIA. SABAH: RANAU, Mount Kinabalu, Tenompok, $5000 \mathrm{ft}$ [1500 m], 24 Feb. 1932, Clemens $\mathcal{E}$ Clemens 28560 (K, L); SIPITANG, HS Merintaman, 19 Oct. 1988, Amin SAN 125954 (K); TAWAU, Oct. 1922 March 1923, Elmer 21895 (K, L, U); TONGOD, South Meliau Basin, Kuamut Highliands, 600 m, 16 April 1988, Campbell 18/4/2 (E); ibid., 17 April 1988, Campbell 19/4/1 (E); SARAWAK: s.d., Native collector 1107 (K, L); 1865 - 68, Beccari 1200 (K); BETONG, Tanjong Keranji, Batang Saribas, 13 June 1971, Nudong $\mathcal{E}$ Kudi S.30050 (E, K, L); KUCHING, Path to Matang, $20 \mathrm{ft}$ [5 m], Haviland 648; near Kuching, 3 March 1893, Haviland 2237 (K, L); ibid., 27 March 1893, Haviland 2237 (K, L); 26 Jan. 1893, Haviland 2862 (K); s.d., Haviland 2862 bis (K); SRI

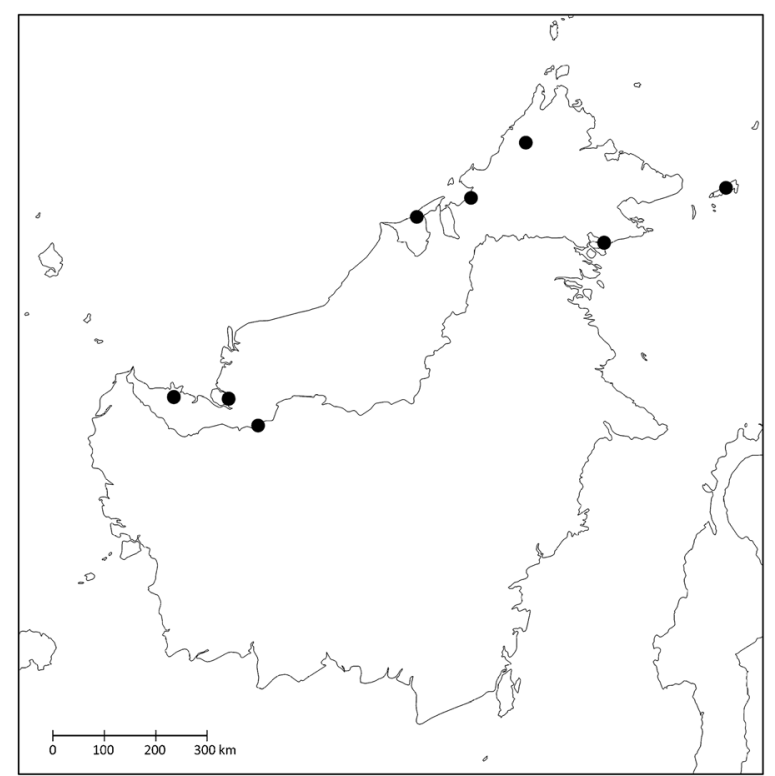

Map 13. Distribution of Ziziphus suluensis $(\bullet)$. 
AMAN, Rh. Wong Pandak, Lubok Antu, Bk. Binjai, 5 March 1985, Awa Ẽ Paie 44126 (K, L).

HABITAT. Borneo lowland and montane rain forests; alt. 5 - $1500 \mathrm{~m}$.

CONSERVATION STATUS. Near Threatened (NT). It is likely that the taxon is declining and severely fragmented given the widespread destruction of rainforests in Borneo. However, the taxon is distributed with an EOO greater than 150,000 $\mathrm{km}^{2}$. Also, the species occurs in montane forests possibly less exposed to heavy exploitation. Some specimens were collected in or near the following protected areas: Tenompok Protection Forest Reserve (IUCN Category Ia) in Sabah; Kubah National Park (IUCN Category II) and Maludam National Park (IUCN Category II) in Sarawak.

PHENOLOGY. Collected in flower in Jan. and Oct.; collected in fruit in Feb., March, June and Dec.

VERNACULAR NAMES. Akar menaul (Iban, fide Nudong $\mathcal{E}$ Kudi S.30050); Kuku Helang (Kedayan, Iban, fide Osman et al. BRUN 16474).

USES. "For ulcer in mouth or tongue. Method: water drain from the stem of Zypus taken and drink" [sic], fide Awa E̊ Paie 44126. Fruits edible (fide Osman et al. BRUN 16474).

NOTES. Ziziphus suluensis is recognised by the presence of abundant dark glands (appearing as black spots) black spots on the leaf lamina, the origin and function of which have not yet been studied. It only shares this character with Ziziphus havilandii from which it differs in having bigger leaves, on average $8 \times 3.5 \mathrm{~cm}$ (vs $2.5-$ $5.5 \times 1.2-2.5 \mathrm{~cm}$ ), widest near the middle (vs usually widest near the base), with more serrations on either side of the margin (>100 vs c. 75 ) and bigger fruits, 1.2 $-1.5 \times 0.9-1.5 \mathrm{~cm}$ (vs on average $0.9 \times 0.8 \mathrm{~cm}$ ). Both species are similar and could represent a single species on the same morphological variability continuum (see Notes for Z. havilandii).

Merrill (1926) cites a Ramos E̋ Edaño collection with the Philippine Bureau of Science number 44295 in the protologue for Ziziphus suluensis and the specimen from UC, where Merrill worked from 1924 - 1929, and which has open flowers, is selected here as the lectotype.

\section{Excluded name}

Ziziphus elmeri Merr. (Merrill 1929: 178) synon. nov. Type: Malaysia, Sabah, Tawao [Tawau], Oct. 1922 March 1923, Elmer 20889 (lectotype, selected here: K [K000723021]; isolectotypes: A [00051551], BR [0000005269235], C [C10017781], CAS [0005255], CM [1373], HBG [HBG-510065], M [M-0211789], P [P06788950, P06790386], PH [00029954], S [S-G6507], SING [SING 0059172], U [U 0115268], UC [UC 290481]). = Colubrina beccariana Warb.
Merrill did not have access to fruits on the material used for his original description of Ziziphus elmeri and therefore did not have capsules as evidence pointing towards a genus other than Ziziphus. Examination of type material of Z. elmeri revealed that it was incorrectly identified material of Colubrina beccariana, a species illustrated and described in detail in the Tree Flora of Sabah and Sarawak (Schirarend 1995).

Merrill (1929) cited Elmer 20889 in the protologue for Ziziphus elmeri and the specimen from UC, where Merrill worked from 1924 - 1929, and which has open flowers, is selected here as the lectotype.

\section{Acknowledgements}

The authors thank Jürgen Kellermann and Ian Turner whose comments and suggestions helped improve and clarify this revision, $P$. Lakshminarasimhan, V. P. Prasad and Avishek Bhattacharjee for their help retrieving type material of Ziziphus kunstleri, and Andrew Brown for his excellent illustrations.

\section{Appendix 1: Alphabetical index to numbered collections examined}

7 Abas SAN 85693 (Ziziphus havilandii); Abas SAN 86009 (Z. horsfieldii); Agama 9466 (Z. crebrivenosa); Ambriansyah AA 2155 (Z. angustifolia); Ambriansyah

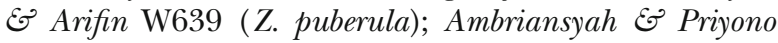
AA 2187 (Z. angustifolia); Ambriansyah AA 2155 (Z. angustifolia); Ambullah 36090 (Z. crebrivenosa); Ambullah 37187 (Z. angustifolia); Amdjah 314 (Z. angustifolia); Amin et al. SAN 67632 (Z. borneensis var. borneensis); Amin SAN 95475 (Z. puberula); Amin SAN 97402 (Z. horsfieldii); Amin SAN 125954 (Z. suluensis); Amin E Donggop SAN 113622 (Z. borneensis var. borneensis); Amin $\mathcal{E}$ Francis SAN 119814 (Z. calophylla); Amin E Francis SAN 119847 (Z. cumingiana var. cumingiana); Amin $\mathcal{E}$ Jarius SAN 116444 (Z. horsfieldii); Amin $\mathcal{E}$ Maidil SAN 108127 (Z. borneensis var. borneensis); Amin et al. SAN 67312 (Z. borneensis var. borneensis); Amin et al. SAN 109777 (Z. cumingiana var. cumingiana); Amin et al. SAN 121074 (Z. cumingiana var. cumingiana); Andau 654 (Z. crebrivenosa); Anderson 12585 (Z. horsfieldii); Anderson 12908 (Z. horsfieldii); Anderson S.27284 (Z. horsfieldii); Apostol 7678 (Z. angustifolia); Argent et al. 451987 (Z. borneensis var. borneensis); Arshid SAN 88621 (Z. angustifolia); Ashton BRUN 867 (Z. kunstleri); Ashton S.7817 (Z. borneensis var. borneensis); Ashton S.12143 (Z. borneensis var. borneensis); Awa E Lee S.47643 (Z. borneensis var. borneensis); Awa E Paie 44126 (Z. suluensis). 
Beaman 10988 (Z. crebrivenosa); Beccari 1200 (Z. suluensis); Beccari 1631 (Z. calophylla); Beccari 2493 (Z. havilandii); Beccari 3377 (Z. kunstleri); Bidin SAN 80728 (Z. borneensis var. borneensis); Bidin SAN 84401 (Z. horsfieldii); Bousi et al. SAN 124340 (Z. horsfieldii); Bukah A 3418 (Z. angustifolia); Burgess SAN 25151 (Z. calophylla).

Campbell 18/4/2 (Z. suluensis); Campbell 19/4/1 (Z. suluensis); Castillo 644 (Z. crebrivenosa); Castro $\mathcal{E}^{\circ}$ Melegrito 1468 (Z. angustifolia); Chai S.22874 (Z. horsfieldii); Chai S.31703 (Z. angustifolia); Chai S.34788 (Z. calophylla); Chai S.39697 (Z. havilandii); Chew Eo Corner RSNB 4894 (Z. havilandii); Chew 1139 (Z. angustifolia); Ching et al. S.64312 (Z. kunstleri); Christensen 1446 (Z. calophylla); Church et al. 14 (Z. angustifolia); Church et al. 96 (Z. borneensis var. ranggam); Church et al. 127 ( $Z$. borneensis var. borneensis); Church et al. 544 (Z. borneensis var. borneensis); Church et al. 834 (Z. havilandii); Clemens E Clemens 7253 (Z. kunstleri); Clemens E Clemens 21688 (Z. havilandii); Clemens Eे Clemens 26722 (Z. puberula); Clemens 27051 (Z. angustifolia); Clemens $\mathcal{E}$ Clemens 27375 (Z. crebrivenosa); Clemens E Clemens 28129 (Z. havilandii); Clemens E Clemens 28560 (Z. suluensis); Clemens E Clemens 28839 (Z. borneensis var. kinabalui); Clemens $\mathcal{E}$ Clemens 28874 (Z. havilandii); Clemens E Clemens 29324 (Z. havilandii); Clemens $\mathcal{E}^{\circ}$ Clemens 30376 (K-sheet 1, Z. havilandii); Clemens $\mathcal{E}$ Clemens 30376 (K-sheet 2, Z. borneensis var. kinabalui); Clemens E Clemens 32195 (Z. havilandii); Clemens E Clemens 33096 (Z. havilandii); Clemens E Clemens 40420 (Z. havilandii); Clemens $\mathcal{E}^{\circ}$ Clemens 50854 (Z. havilandii); Clemens Eै Clemens 7229 [20144] (Z. ridleyana); Coode et al. 6318 (Z. angustifolia); Coode et al. 6900 (Z. borneensis var. borneensis); Coode et al. 7052 (Z. angustifolia); Coode et al. 7688 (Z. borneensis var. borneensis).

Davis et al. 453 (Z. borneensis var. borneensis); Dransfield E Boyce 6667 (Z. puberula); Dransfield et al. JD 7157 (Z. havilandii).

Elleh SAN 34357 (Z. borneensis var. borneensis); Elmer 20149 (Z. borneensis var. borneensis); Elmer 20361 (Z. borneensis var. borneensis); Elmer 20880 (Z. crebrivenosa); Elmer 21383 (Z. cumingiana var. cumingiana); Elmer 21813 (Z. crebrivenosa); Elmer 21895 (Z. suluensis); Embun SAN 101239 (Z. cuspidata); Endert 2411 (Z. cumingiana var. cumingiana); Endert 3114 (Z. havilandii); Endert 3607 (Z. havilandii); Endert 4061 (Z. puberula); Endert 4946 (Z. calophylla); Enggoh 10522 (Z. calophylla); Eryani et al. S.98444 (Z. calophylla).

Forman E⿱ B Blewett 862 (Z. borneensis var. borneensis).

Gambukas et al. SAN 108026 (Z. borneensis var. borneensis); Gansau SAN 54499 (Z. borneensis var. borneensis); George Ẽ Amin SAN 121297 (Z. puberula);
Gibot SAN 40901 (Z. borneensis var. borneensis); Gibot SAN 64335 (Z. angustifolia); Gibot SAN 64377 (Z. horsfieldii); Gibot SAN 83221 (Z. havilandii); Gibot SAN 91255 (Z. cuspidata); Gibot SAN 96929 (Z. horsfieldii); Gibot E Singh SAN 30014 (Z. calophylla).

Hallier 811 (Z. horsfieldii); Hallier 1112 (Z. cumingiana var. cumingiana); Hallier 1351 (Z. kunstleri); Hallier 3209 (Z. borneensis var. borneensis); Han et al. SAN 99846 (Z. cuspidata); Haviland 648 (Z. suluensis); Haviland 807 (Z. havilandii); Haviland 881 (Z. ridleyana); Haviland 884 (Z. kunstleri); Haviland 1765 (Z. borneensis var. borneensis); Haviland 2134 (Z. havilandii); Haviland 2237 (Z. suluensis); Haviland 2862 (Z. suluensis); Hazlinah et al. S.86696 (Z. angustifolia); Hock S.40631 (Z. angustifolia); Hock S.46435 (Z. angustifolia); Hose 169 (Z. horsfieldii); Hose 698 (Z. horsfieldii).

Ja'amat KEP 39641 (Z. angustifolia); Jacobs 5328 (Z. cuspidata); Jarvie E Ruskandi 6235 (Z. cuspidata); Jimpin SAN 118831 (Z. calophylla); Johns et al. 6967 (Z. puberula); Joseph et al. SAN 123657 (Z. cumingiana var. cumingiana); Joseph et al. SAN 123665 (Z. puberula); Julaihi et al. S.76946 (Z. angustifolia); Julia et al. S.98021 (Z. calophylla); Jumatin 77406 (Z. borneensis var. borneensis).

Kalat et al. BRUN 17692 (Z. havilandii); Kalat et al. BRUN 17809 (Z. borneensis var. borneensis); Kalat et al. BRUN 17810 (Z. havilandii); Kanis E Kuripin SAN 54380 (Z. cuspidata); Kessler et al. 775 (Z. borneensis var. borneensis); Kessler et al. 911 (Z. kunstleri); Kloss SFN 19064 (Z. borneensis var. borneensis); Kokawa E Hotta 5781 (Z. havilandii); Kostermans 4041 (Z. havilandii); Kostermans 4205 (Z. havilandii); Kostermans 5032 (Z. angustifolia); Kostermans 6917 (Z. angustifolia); Kostermans 9688 (Z. havilandii); Kostermans 10234 (Z. havilandii); Kostermans 21286 (Z. crebrivenosa); Kramadibrata 202 (Z. crebrivenosa); Krispinus SAN 89801 (Z. borneensis var. borneensis); Krispinus SAN 113272 (Z. angustifolia); Krispinus SAN 125205 (Z. cuspidata); Krispinus SAN 125255 (Z. cuspidata); Krispinus SAN 136978 (Z. havilandii); Krispinus $\mathcal{E}^{\circ}$ Jimpin SAN 91809 (Z. borneensis var. borneensis); Krispinus $\mathcal{E}$ Jimpin SAN 91877 (Z. borneensis var. borneensis); Krispinus $\mathcal{E}$ Suali SAN 101212 (Z. borneensis var. borneensis); Krispinus E Sumbing SAN 91399 (Z. horsfieldii); Krispinus E Sumbing SAN 110913 (Z. havilandii); Krispinus E Sumbing SAN 113903 (Z. cuspidata); Kudi S.23703 (Z. havilandii); Kumin SAN 75600 (Z. cumingiana var. cumingiana).

Laman et al. 142 (Z. borneensis var. borneensis); Lai et al. S.75301 (Z. angustifolia); Latupeirissa 95006 (Z. kunstleri); Leighton 77 (Z. calophylla); Leighton 361 (Z. calophylla); Leighton 487 (Z. cumingiana var. cumingiana); Luang S. 21735 (Z. crebrivenosa); Luang S.23451 (Z. horsfieldii); Lugas 1229 (Z. angustifolia); 
Lugas 2310 (Z. crebrivenosa); Lugas 2495 (Z. crebrivenosa).

Madani SAN 36786 (Z. borneensis var. velutina); Madani SAN 76313 (Z. crebrivenosa); Madani SAN 77372 (Z. angustifolia); Madani SAN 81174 (Z. cumingiana var. cumingiana); Madani SAN 88843 (Z. angustifolia); Madani E Krispinus SAN 88461 (Z. crebrivenosa); Maidi 1534 (Z. borneensis var. borneensis); Maikin et al. SAN 30679 (Z. horsfieldii); Majawat et al. SAN 102438 (Z. angustifolia); Mansus Eे Amin SAN 106660 (Z. horsfieldii); Mantor SAN 120247 (Z. horsfieldii); Mantor SAN 122037 (Z. calophylla); Martin S.38200 (Z. angustifolia); Meijer 41042 (Z. horsfieldii); Meijer SAN 27921 (Z. angustifolia); Meijer SAN 136518 (Z. cuspidata); Mikil SAN 31565 (Z. angustifolia); Mikil SAN 40341 (Z. angustifolia); Mohtar et al. S.47160 (Z. angustifolia); Mohtar et al. S.47197 (Z. angustifolia); Moulton 46 (Z. puberula); Munting E Jugah S.55601 (Z. angustifolia); Murata B 2759 (Z. havilandii).

Nangkat et al. BRUN 15775 (Z. cuspidata); Native collector 1107 (Z. suluensis); Native collector 113 (Z. kunstleri); Nooteboom E Chai 2170

(Z. havilandii); Nudong E Kudi S.30050 (Z. suluensis).

Ogata 11380 (Z. cumingiana var. cumingiana); Orolfo 4153 (Z. borneensis var. borneensis); Osman et al. BRUN 16474 (Z. suluensis); Osman et al. BRUN 16491 (Z. cuspidata); Othman et al. S.57735 (Z. crebrivenosa); Othman et al. S.57743 (Z. kunstleri).

Paie Ẽ Dami S.43778 (Z. borneensis var. borneensis); Paie S.15569 (Z. angustifolia); Paie S.26187 (Z. angustifolia); Paie S.35742 (Z. havilandii); Paie S.38463 (Z. borneensis var. borneensis); Paie S.39200 (Z. borneensis var. ranggam); Paie S.41581 (Z. borneensis var. ranggam); Paie S.50173 (Z. angustifolia); Pikkoh SAN 116849 (Z. horsfieldii); Pius et al. SAN 149351 (Z. puberula); Poore H 441 (Z. havilandii); Puasa E Enggoh 10623 (Z. angustifolia); Puasa 7201 (Z. angustifolia); Puasa 10098 (Z. cumingiana var. cumingiana); Puasa NBF 10106 (Z. angustifolia); Purseglove P.5407 (Z. kunstleri).

Radin 4191 (Z. borneensis var. borneensis); Ramos 1462 (Z. borneensis var. borneensis); Rantai E Tinjan S. 68738 (Z. angustifolia); Rena et al. S. 60744 (Z. havilandii); Ridsdale et al. CEROL 18 (Z. borneensis var. borneensis); Ridsdale PBU 628 (Z. cuspidata); Rutten 754 (Z. cumingiana var. cumingiana).

Sam SAN 49929 (Z. borneensis var. borneensis); Sambuling 524 (Z. calophylla); Sands et al. 5369 (Z. havilandii); Sands et al. 5717 (Z. borneensis var. borneensis); Sidiyasa PBU 609 (Z. borneensis var. borneensis); Simbut SAN 100309 (Z. puberula); Simpson E Marsh 2006 (Z. calophylla); Sinanggul SAN 57017 (Z. puberula); Sinclair 10520 (Z. calophylla); Sinclair
Singapore Field No. 38323 (Z. kunstleri); Slik MEPRI 4529 (Z. havilandii); Soibeh 201 (Z. havilandii); Soibeh 627 (Z. angustifolia); Soibeh 642 (Z. cuspidata); Suali E。 Pikkoh SAN 96499 (Z. borneensis var. borneensis); Sumbing SAN 128564 (Z. cuspidata); Sundaling SAN 97021 (Z. crebrivenosa); Sundaling SAN 107497 (Z. angustifolia); Sundaling SAN 129538 (Z. borneensis var. borneensis); Sundaling E Karim SAN 77793 (Z. horsfieldii); Sundaling et al. SAN 135259 (Z. angustifolia); Suzana et al. S.97545 (Z. havilandii).

Tadong 247 (Z. cumingiana var. cumingiana); Tikau SAN 28913 (Z. borneensis var. velutina); Tong et al. S.34293 (Z. havilandii); Tong S.34959 (Z. angustifolia)

de Vogel 1667 (Z. angustifolia); de Vogel 1774 (Z. puberula); de Vogel 2196 (Z. angustifolia).

Wat et al. S.76303 (Z. havilandii); Wilkie 94133 (Z. kunstleri); Wilkie 94312 (Z. havilandii); Wiriadinata 3199 (Z. kunstleri); Wiriadinata 3539 (Z. borneensis var. borneensis); Wong WKM 1281 (Z. horsfieldii); Wong WKM 1598 (Z. havilandii); Wood E ${ }^{2}$ Wyatt-Smith A 4387 (Z. havilandii); Wood 1961 (Z. borneensis var. borneensis); Wood A 4674 (Z. calophylla); Wood SAN 16070 (Z. crebrivenosa).

Yii S.56905 (Z. borneensis var. borneensis); Yii S.56911 (Z. borneensis var. borneensis); Yii S.40106 (Z. borneensis var. borneensis); Yii S.44186 (Z. angustifolia); Yii Ev Talib S.58894 (Z. puberula); Yii et al. S.72598 (Z. horsfieldii).

Open Access This article is licensed under a Creative Commons Attribution 4.0 International License, which permits use, sharing, adaptation, distribution and reproduction in any medium or format, as long as you give appropriate credit to the original author(s) and the source, provide a link to the Creative Commons licence, and indicate if changes were made. The images or other third party material in this article are included in the article's Creative Commons licence, unless indicated otherwise in a credit line to the material. If material is not included in the article's Creative Commons licence and your intended use is not permitted by statutory regulation or exceeds the permitted use, you will need to obtain permission directly from the copyright holder. To view a copy of this licence, visit http://creativecommons.org/ licenses/by/4.0/.

\section{References}

Bachman, S., Moat, J., Hill, A., de la Torre, J. \& Scott, B. (2011). Supporting Red List threat assessments with GeoCAT: Geospatial Conservation Assessment Tool. ZooKeys 150: 117 - 126.

Baker, E. G. (1923). Dr. H. O. Forbes's New 
Guinean Plants. J. Bot. 61 (Suppl.): 1 - 64.

Beaman, J. H. \& Anderson, C. (2004). The Plants of Mount Kinabalu 5: Dicotyledon Families Magnoliaceae to Winteraceae. Natural History Publications (Borneo), Kota Kinabalu and Royal Botanic Gardens, Kew.

Beentje, H. (2010). The Kew Plant Glossary: An Illustrated Dictionary of Plant Terms. Royal Botanic Gardens, Kew.

Brongniart, A. T. (1843). Énumération de Genres de Plantes Cultivés au Muséum d'Histoire Naturelle de Paris. Fortin, Masson et Cie., Paris.

Cahen, D. \& Utteridge, T. M. A. (2017). Three new species of Ventilago (Rhamnaceae) from South-East Asia. Phytotaxa 307 (3): 171 - 182. \& _ (2018). A synopsis of the genus Smythea (Rhamnaceae). Kew Bull. 73: 2.

, Stenn, K. S. \& Utteridge, T. M. A. (2020). A revision of the genus Gouania (Rhamnaceae) in the Philippines and Sundaland. Kew Bull. 75(1).

Cannon, C. H., Summers, M., Harting, J. R. \& Kessler, P. J. (2007). Developing Conservation Priorities Based on Forest Type, Condition, and Threats in a Poorly Known Ecoregion: Sulawesi, Indonesia. Biotropica 39: 747 - 759.

Dinerstein, E., Olson, D., Joshi, A., Vynne, C., Burgess, N., Wikramanayake, E., Hahn, N., Palminteri, S., Hedao, P., Noss, R., Hansen, M., Locke, H., Ellis, E., Jones, B., Barber, C., Hayes, R., Kormos, C., Martin, V., Crist, E., Sechrest, W., Price, L., Baillie, J., Weeden, D., Suckling, K., Davis, C., Sizer, N., Moore, R., Thau, D., Birch, T., Potapov, P., Turubanova, S., Tyukavina, A., de Souza, N., Pintea, L., Brito, J., Llewellyn, O., Miller, A., Patzelt, A., Ghazanfar, S., Timberlake, J., Klöser, H., ShennanFarpón, Y., Kindt, R., Lillesø, J., van Breugel, P., Graudal, L., Voge, M., Al-Shammari, K. \& Saleem, M. (2017). An Ecoregion-Based Approach to Protecting Half the Terrestrial Realm. BioScience 67 (6): $534-545$.

Don, G. (1832). A General History of the Dichlamydeous Plants, Vol. 2. Rivington and others, London.

Elmer, A. D. E. (1913). Four Score of New Plants. Leafl. Philipp. Bot. 5: $1751-1853$.

Gaveau, D. L. A., Sloan, S., Molidena, E., Yaen, H., Sheil, D., Abram, N. K., Ancrenaz, M., Nasi, R., Quinones, M., Wielaard, N. \& Meijaard, E. (2014). Four Decades of Forest Persistence, Clearance and Logging on Borneo. PLOS ONE 9 (7): e101654.

GBIF (2019). GBIF Occurrence Download. Available from: https://doi.org/10.15468/dl.jaj1ew. Accessed: 4 Sept 2019.

Hauenschild, F., Matuszak, S., Muellner-Riehl, A. N. \& Favre, A. (2016). Phylogenetic relationships within the cosmopolitan buckthorn family (Rhamnaceae) support the resurrection of Sarcomphalus and the description of Pseudoziziphus gen. nov. Taxom 65 (1): 47 - 64 .
Hickey, L. J. (1979). A revised classification of the architecture of dicotyledonous leaves. In: C. R. Metcalfe \& L. Chalk (eds), Anatomy of the dicotyledons. Second Edition. Vol. 1. Systematic anatomy of the leaf and stem, pp. 25 - 39. Oxford Science Publications, Oxford.

Hooker, J. D. (1862). Rhamnaceae. In: G. Bentham \& J. D. Hooker (eds), Genera Plantarum. Vol. 1: 371 386. Reeve \& Co., London.

Islam, M. \& Simmons, M. P. (2006). A Thorny Dilemma: Testing Alternative Intrageneric Classifications within Ziziphus (Rhamnaceae). Syst. Bot. 31 (4): $826-842$.

IUCN \& UNEP-WCMC (2019). The World Database on Protected Areas (WDPA). Cambridge, UK. Available from: www.protectedplanet.net. Accessed: 4 Sept. 2019.

Kartawinata, K. (2008). Floristics and Structure of a Lowland Dipterocarp Forest at Wanariset Samboja, East Kalimantan, Indonesia. Reinwardtia 12 (4): 301 -323 .

Kellermann, J. (2020). Nomenclatural notes and typifications in Australian species of Paliureae (Rhamnaceae). Swainsona 33: 43 - 50.

King, G. (1896). Materials for a Flora of the Malayan Peninsula. J. Asiat. Soc. Bengal, Pt. 2, Nat. Hist. 65 (3): $339-546$.

Latiff, A. M. (1991). Ziziphus mauritiana Lamk. In: E. W. M. Verheij \& R. E. Coronel (eds), Plant Resources of South-East Asia. Vol. 2. Edible fruits and nuts, pp. 310 - 312. PUDOC, Wageningen.

Liu, M. J. \& Cheng, C. Y. (1995). A taxonomic study of the genus Ziziphus. Acta Hort. 390: 161 - 165.

Masamune, G. (1942). Enumeratio Phanerogamarum Bornearum. Taihoku University, Taiwan.

Medan, D. \& Schirarend, C. (2004). Rhamnaceae. In: K. Kubitzki (ed.), The Families and Genera of Vascular Plants, Vol. 6: Celastrales, Oxalidales, Rosales, Cornales, Ericales, pp. 320 - 338. Springer Verlag, Berlin, Heidelberg.

Merrill, E. D. (1905). New or Noteworthy Philippine Plants, IV. Publ. Bur. Sci. Gov. Lab. 35: 5 - 68. (1906). New or Noteworthy Philippine Plants, V. Philipp. J. Sci. 1 (Suppl. 3): 169 - 246.

(1922). Additions to our Knowledge of the Bornean Flora. Philipp. J. Sci. 21 (6): 515 - 534. (1923). Rhamnaceae. In: E. D. Merrill (ed.), An Enumeration of Philippine Plants, Vol. 2, Fasc. 5, pp. 521 - 526. Bureau of Printing, Manila.

(1926). Additions to our Knowledge of the Philippine Flora III. Philipp. J. Sci. 30 (4): 389 - 430. (1929). Plantae Elmerianae Borneenses. Univ.

Calif. Publ. Bot. 15: 1 - 301.

(1943). Destruction of the Berlin Herbarium. Science 3: 490 - 491.

Miquel, F. A. W. (1856). Flora van Nederlandsch Indië, Vol. 1. C. G. van der Post, Amsterdam. 
(1861). Flora van Nederlandsch Indië. Erste bijvoegsel. Sumatra, zijne plantenwereld en hare voortbrengselen. C. G. van der Post, Amsterdam.

Perry, L. M. (1954). A New Combination in Ziziphus (Rhamnac.). Blumea 7: 595 - 596.

Persoon, G. A. \& Osseweijer, M. (2008). Reflections on the Heart of Bormeo. Tropenbos International, Wageningen.

Planchon, J. E. (1873). Ulmaceae. In: A. P. de Candolle (ed.), Prodromus Systematis Naturalis Regni Vegetabilis, Vol. 17: 151 - 210. Masson, Paris.

POWO (2019). Plants of the World Online. Facilitated by the Royal Botanic Gardens, Kew. Available from: http:// www.plantsoftheworldonline.org/. Accessed: 4 Sept. 2019.

Rasingam, L. \& Karthigeyan, K. (2020). Ziziphus ridleyana, a new name for Ziziphus macrophylla Ridl. (Rhamnaceae). Phytotaxa 454 (1): 71 - 72.

Richardson, J. E., Fay, M. F., Cronk, Q. C. B., Bowman, D. \& Chase, M. W. (2000). A Phylogenetic Analysis of Rhamnaceae using rbcL and trnL-F Plastid DNA Sequences. Amer. J. Bot. 87: 1309 - 1324.

Chatrou, L. W., Mols, J. B., Erkens, R. H. \& Pirie, M. D. (2004). Historical biogeography of two cosmopolitan families of flowering plants: Annonaceae and Rhamnaceae. Philos. Trans., Ser. B 359 (1450): 1495 - 1508.

Ridley, H. N. (1931). Additions to the Flora of Borneo and Other Malay Islands: III. Bull. Misc. Inform., Kew 1931 (10): 493 - 499.

Robinson, C. B. (1908). Alabastra Philippinensia, II. Philipp. J. Sci., C (4): $175-218$.

Roxburgh, W. (1824). Flora Indica, Vol. 2. Mission Press, Serampore.

Schimper, W. P. (1874). Traité de Paléontologie Végétale, Vol. 3. J. B. Baillière et Fils, Paris, Baillière, Tindall and Cox, London, Carlos Bailly-Baillière, Madrid.

Schirarend, C. (1995). Rhamnaceae. In: E. Soepadmo \& K. M. Wong, Tree Flora of Sabah and Sarawak 1: 305 - 319. Forest Research Institute Malaysia, Sabah Forestry Department and Sarawak Forestry Department, Kuala Lumpur.

\& Olabi M. N. (1994). Revision of the genus Paliurus Tourn. ex Mill. (Rhamnaceae). Bot. Jahrb. Syst. 116 (3): $333-360$.
Suessenguth, K. (1950). Amaranthaceae, Asclepiadaceae, Combretaceae, Geraniaceae, Meliaceae, Myrtaceae, Rhamnaceae, Rubiaceae. Mitt. Bot. Staatssamml. München 1 (1): 1 - 32.

(1953). Rhamnaceae. In: A. Engler \& K. Prantl (eds), Die Natürlichen Pflanzenfamilien Zweite Auflage Band 20d, pp. 1 - 173. Duncker and Humbolt, Berlin.

\& Overkott, O. (1941). Einige neue und bemerkenswerte Rhamnaceen aus den Herbarien Berlin und München. Repert. Spec. Nov. Regni Veg. 50: 325 - 332.

van Steenis, C. G. G. J. (1960). Miscellaneous Notes on New Guinea Plants VI. Nova Guinea, Bot. 3: 13 - 19.

Turland, N. J., Wiersema, J. H., Barrie, F. R., Greuter, W., Hawksworth, D. L., Herendeen, P. S., Knapp, S., Kusber, W.-H., Li, D.-Z., Marhold, K., May, T. W., McNeill, J., Monro, A. M., Prado, J., Price, M. J. \& Smith, G. F. (eds) (2018). International Code of Nomenclature for algae, fungi, and plants (Shenzhen Code) adopted by the Nineteenth International Botanical Congress Shenzhen, China, July 2017. Regnum Veg. 159. Koeltz Botanical Books, Glashütten.

Viloria, B. H. R., Indelible, D. P., van Rij, W. \& Tabbada, A. U. (2005). Balancing biodiversity conservation and incomes of upland communities: approaches and experiences of the upland development programme in Southern Mindanao. In: 14th Annual Philippine Biodiversity Symposium of the Wildlife Conservation Society of the Philippines, pp. 1 - 28. Crown Lodge, Tuguegarao, Cagayan. Warburg, O. (1891). Beiträge zur Kenntnis der papuanischen Flora. Bot. Jahrb. Syst. 13 (3 - 4): 273 - 455.

Weberbauer, A. (1895). Rhamnaceae. In: A. Engler \& K. Prantl (eds), Die Natürlichen Pflanzenfamilien III. Teil 5. Abteilung, pp. 393 - 427. W. Engelmann, Leipzig.

\section{Publisher's Note}

Springer Nature remains neutral with regard to jurisdictional claims in published maps and institutional affiliations. 